\title{
Prototype Courthouse Building Energy Model: Building and System Characteristics
}

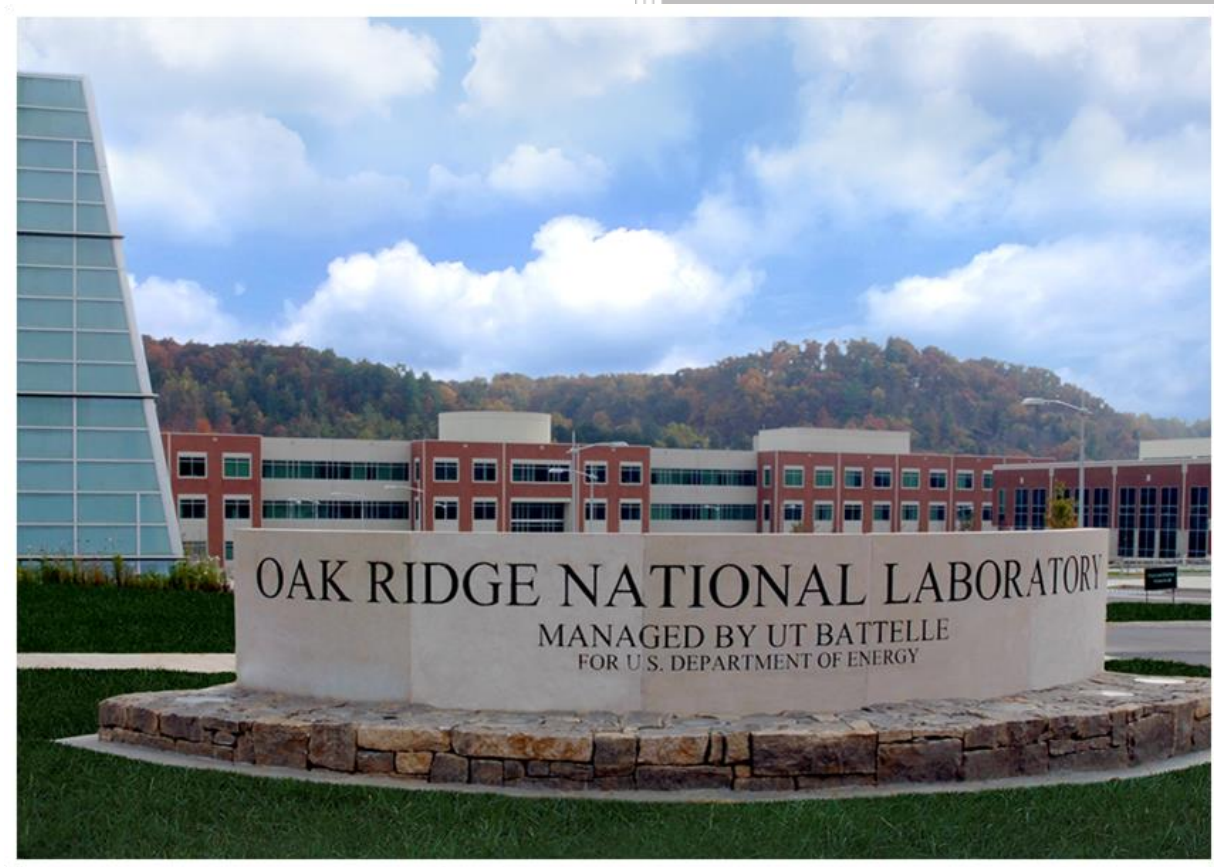

Approved for public release. Distribution is unlimited.

Mini Malhotra, $\mathrm{PhD}$ Joshua New, PhD Piljae Im, PhD

February 2018 


\title{
DOCUMENT AVAILABILITY
}

Reports produced after January 1, 1996, are generally available free via US Department of Energy (DOE) SciTech Connect.

Website www.osti.gov

Reports produced before January 1, 1996, may be purchased by members of the public from the following source:

\author{
National Technical Information Service \\ 5285 Port Royal Road \\ Springfield, VA 22161 \\ Telephone 703-605-6000 (1-800-553-6847) \\ TDD 703-487-4639 \\ Fax 703-605-6900 \\ E-mail info@ntis.gov \\ Website http://classic.ntis.gov/
}

Reports are available to DOE employees, DOE contractors, Energy Technology Data Exchange representatives, and International Nuclear Information System representatives from the following source:

Office of Scientific and Technical Information

PO Box 62

Oak Ridge, TN 37831

Telephone 865-576-8401

Fax 865-576-5728

E-mail reports@osti.gov

Website http://www.osti.gov/contact.html

This report was prepared as an account of work sponsored by an agency of the United States Government. Neither the United States Government nor any agency thereof, nor any of their employees, makes any warranty, express or implied, or assumes any legal liability or responsibility for the accuracy, completeness, or usefulness of any information, apparatus, product, or process disclosed, or represents that its use would not infringe privately owned rights. Reference herein to any specific commercial product, process, or service by trade name, trademark, manufacturer, or otherwise, does not necessarily constitute or imply its endorsement, recommendation, or favoring by the United States Government or any agency thereof. The views and opinions of authors expressed herein do not necessarily state or reflect those of the United States Government or any agency thereof. 
Energy and Transportation Science Division

\title{
PROTOTYPE COURTHOUSE BUILDING ENERGY MODEL: BUILDING AND SYSTEM CHARACTERISTICS
}

\author{
Mini Malhotra, $\mathrm{PhD}$ \\ Joshua New, $\mathrm{PhD}$ \\ Piljae Im, PhD
}

Date Published: February 2018

\author{
Prepared by \\ OAK RIDGE NATIONAL LABORATORY \\ Oak Ridge, TN 37831-6283 \\ managed by \\ UT-BATTELLE, LLC \\ for the \\ US DEPARTMENT OF ENERGY \\ under contract DE-AC05-00OR22725
}





\section{TABLE OF CONTENTS}

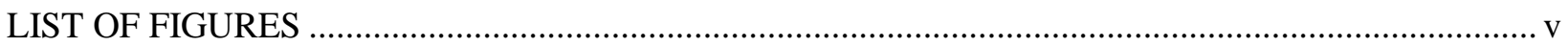

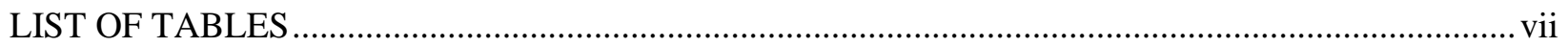

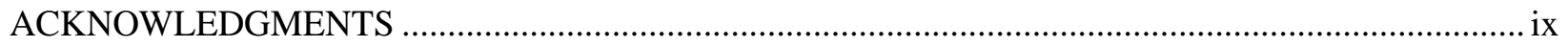

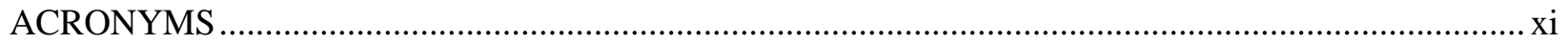

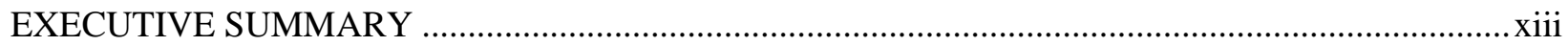

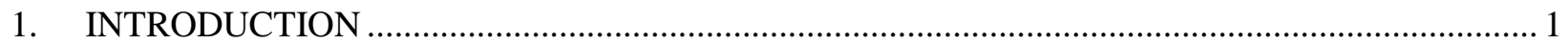

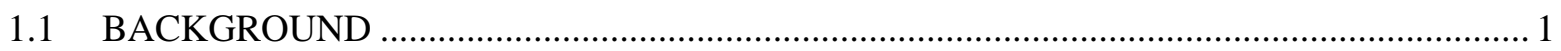

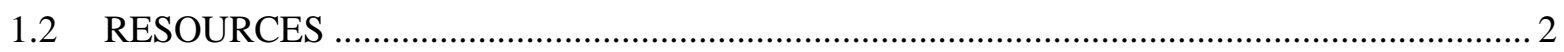

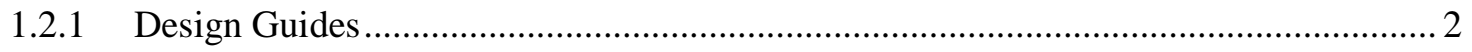

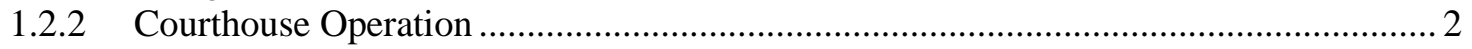

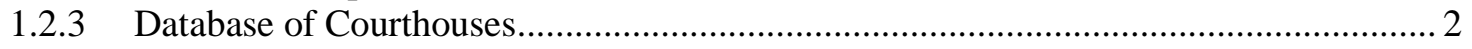

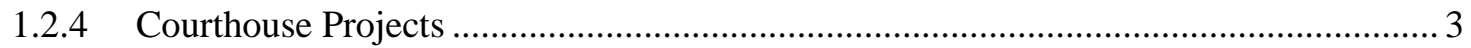

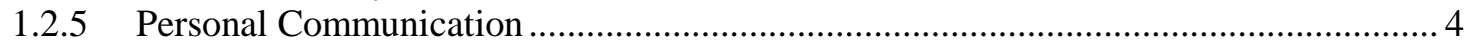

1.3 COURTHOUSE VERSUS OTHER BUILDINGS IN CBECS ........................................... 4

1.3.1 Percent of Total Commercial Building Floor Space …............................................ 4

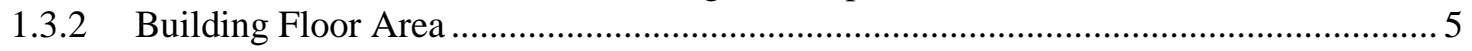

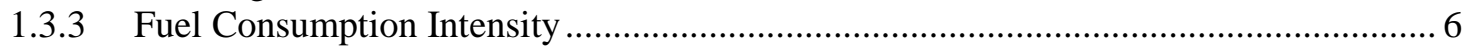

2. OVERVIEW OF COURTHOUSES IN THE UNITED STATES ................................................ 7

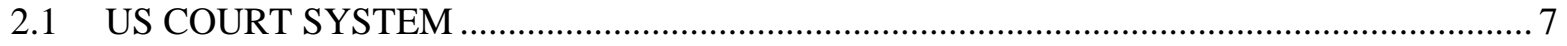

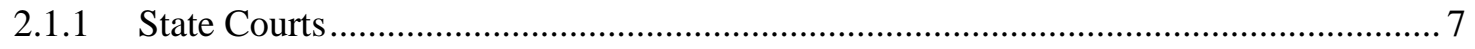

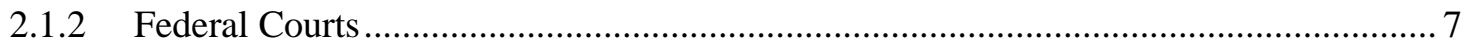

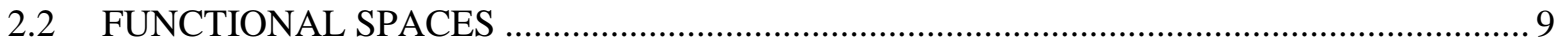

2.3 KEY OPERATIONAL AND ORGANIZATIONAL CONCEPTS .................................... 10

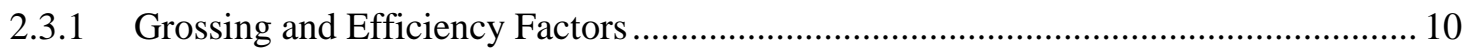

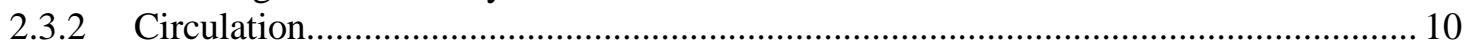

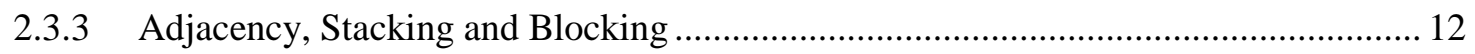

2.4 BUILDING SIZE AND SPACE REQUIREMENT DETERMINANTS .............................. 16

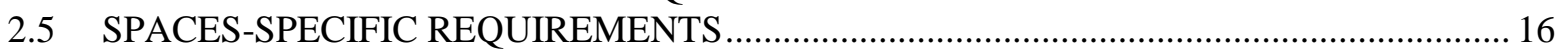

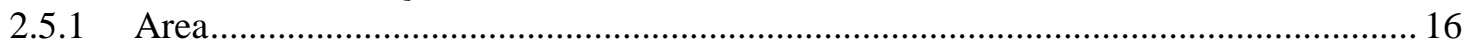

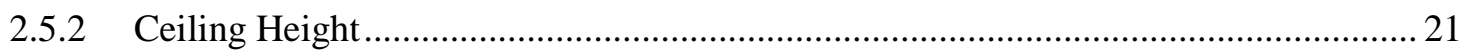

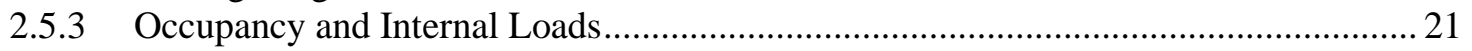

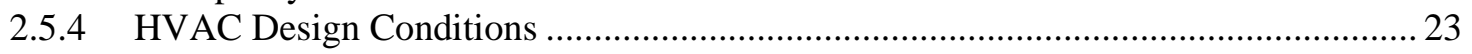

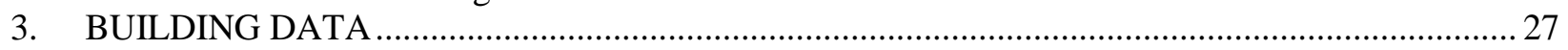

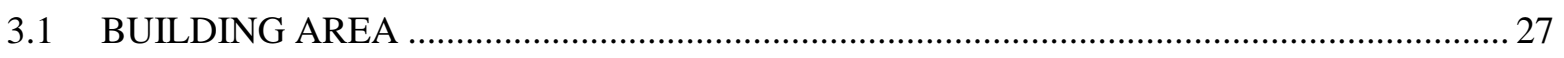

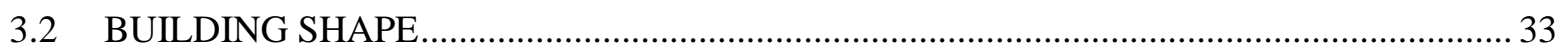

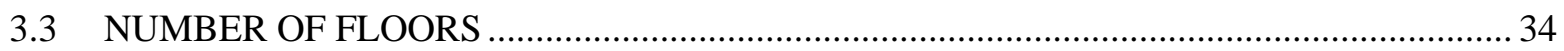

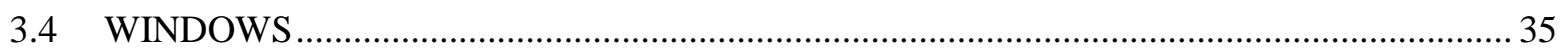

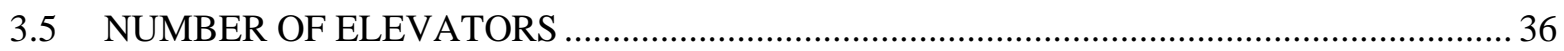

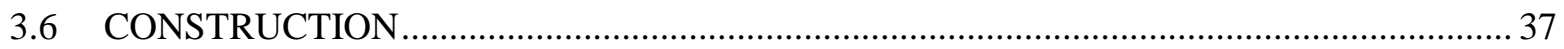

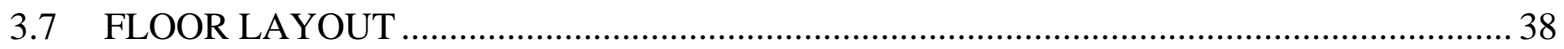

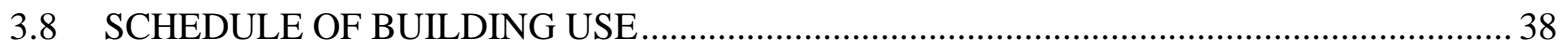

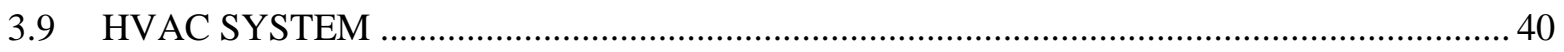

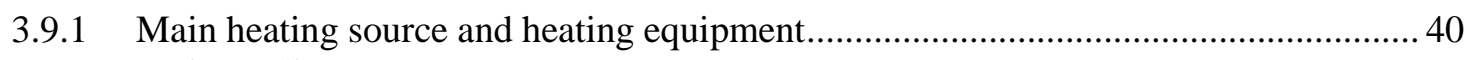

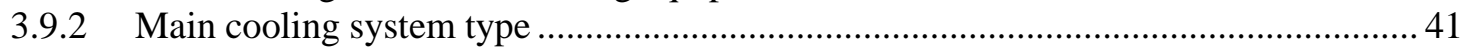

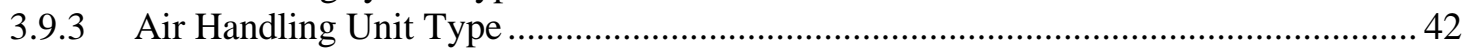

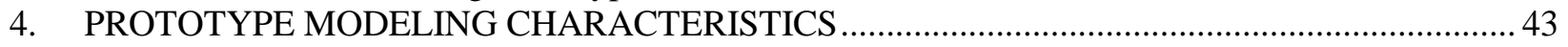

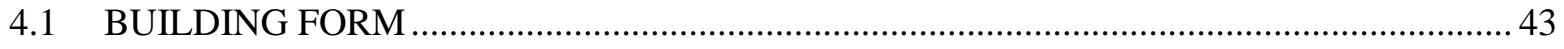

4.1.1 Floor Area, Number of Floors, and Building Shape ............................................... 43 
4.1.2 Window Fraction and Window Locations

.43

4.1.3 Floor Height

4.1.4 Layout of Spaces.

4.2 STRUCTURE

47

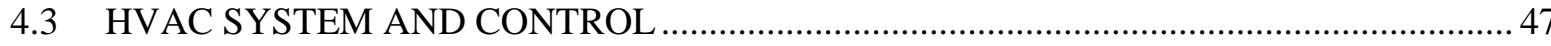

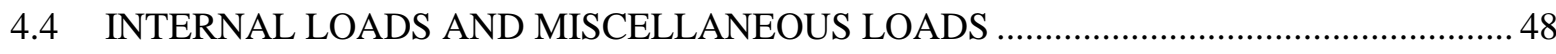

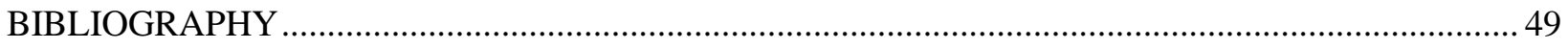

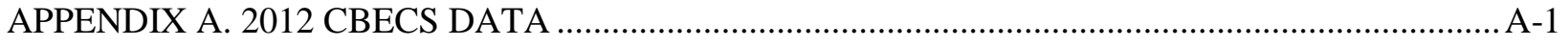

APPENDIX B. GSA US COURTHOUSE PORTFOLIO DATA …................................................. B-1 


\section{LIST OF FIGURES}

Figure 1. Percent of total building floor space for courthouses compared to other buildings. .................... 5

Figure 2. Building floor area for courthouse compared to other buildings........................................... 5

Figure 3. Fuel consumption intensity statistics for courthouse versus other buildings............................ 6

Figure 4. Fuel consumption intensity versus mean floor area for courthouse versus other

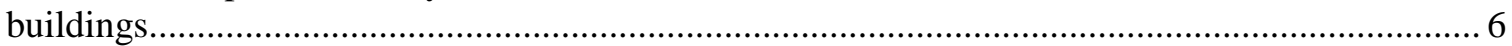

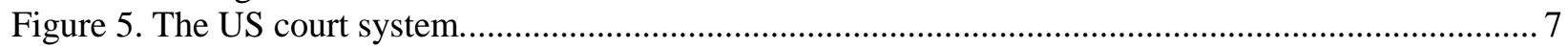

Figure 6. Geographic boundaries of federal courts (courts of appeal and district courts). ........................ 8

Figure 7. Section showing three part circulation system. ..................................................................... 11

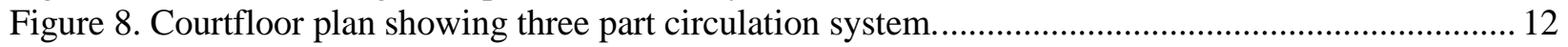

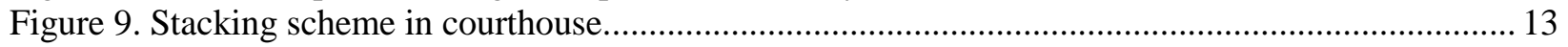

Figure 10. Blocking scheme in courtroom floor (public, private and interface zones)............................ 14

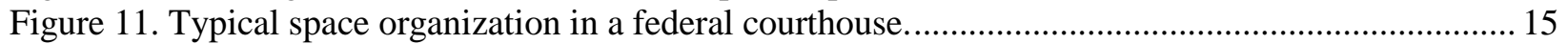

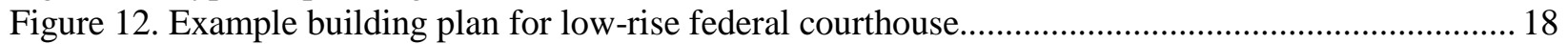

Figure 13. Example building plan for mid-rise federal courthouse. ........................................................ 19

Figure 14. Example building plan for high-rise federal courthouse .................................................... 20

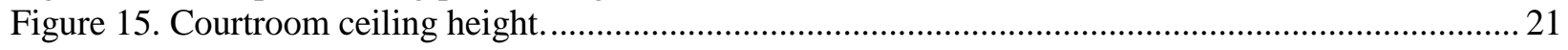

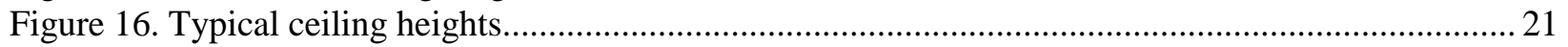

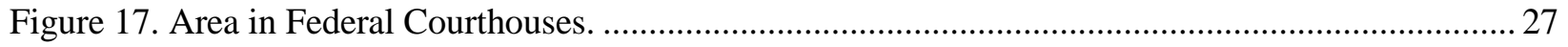

Figure 18. Percentage frequency and cumulative percentage frequency of federal courthouses by

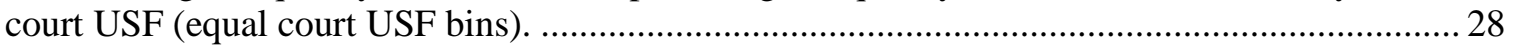

Figure 19. Percentage frequency of federal courthouse court USF (increasing bin size) ........................ 29

Figure 20. Percentage frequency of courthouse square footage categories (increasing bin size).............. 30

Figure 21. Percentage frequency of 2012 CBECS sample courthouse square footage............................. 30

Figure 22. Building floor area for commercial building prototype models compared to 2003 and

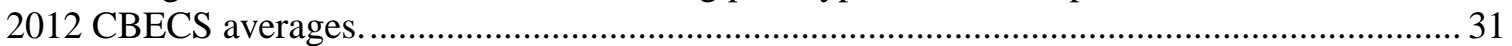

Figure 23. Percentage frequency of building gross square feet (increasing bin size).............................. 32

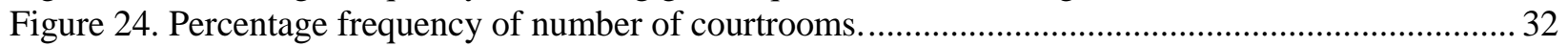

Figure 25. Correlation between number of courtrooms and building gross square feet. ........................... 33

Figure 26. Percentage frequency of courthouse building shape. (Source: EIA 2015) ............................. 33

Figure 27. Aspect ratio of buildings under the Public Order and Safety category.................................... 34

Figure 28. Percentage frequency of courthouse number of floors. ....................................................... 35

Figure 29. Percentage frequency of percent exterior glass in courthouse............................................. 35

Figure 30. Number of elevators versus (a) building square footage, (b) number of floors....................... 37

Figure 31. Schedule of operation on weekdays in 31 federal courthouses. ............................................ 39

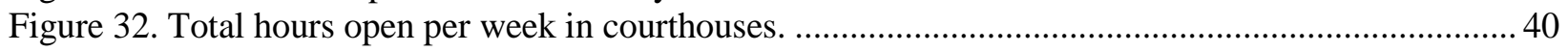

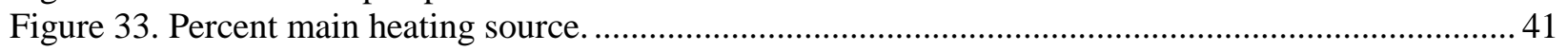

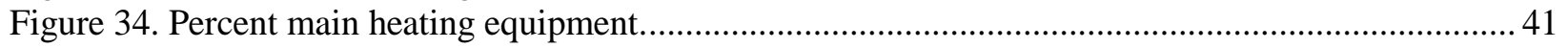

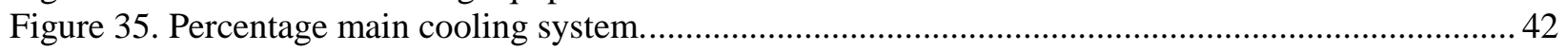

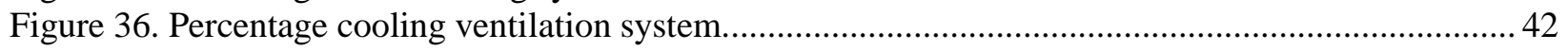

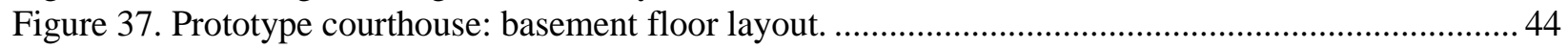

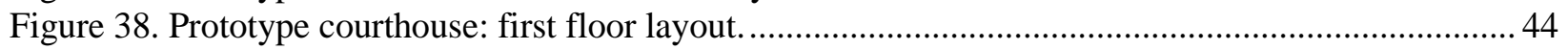

Figure 39. Prototype courthouse: second floor layout. ...................................................................... 45 



\section{LIST OF TABLES}

Table 1. Example area program for low-rise, mid-rise and high-rise federal courthouse........................ 17

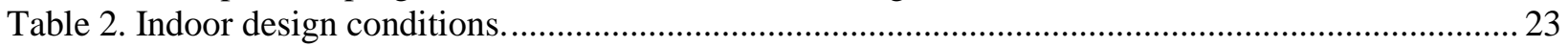

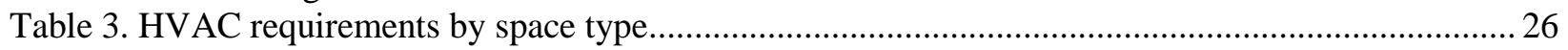

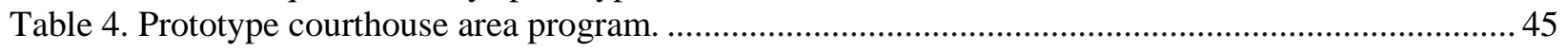





\section{ACKNOWLEDGMENTS}

This work was funded by field work proposal CEBT105 under the Department of Energy Building Technology Activity Number BT0201000. We would like to thank Amir Roth for his support and review of this project.

The authors acknowledge several individuals and organizations who have provided significant help in conducting this research.

Don Hardenbergh, Court Works

Michael Griebel, Research Design Solutions LLC

John Sporidis, Vanderweil Engineers

Henry Pittner, AIA, BVK Group Architects \& Engineers

Bob Schwartz, HOK

Bob S. Slattery, Oak Ridge National Laboratory

Bing Liu, Pacific Northwest National Laboratory

Mark Halverson, Pacific Northwest National Laboratory

National Center for States Courts

US General Services Administration

The Federal Judiciary of the United States 



\section{ACRONYMS}

AHU air handling unit

AIA

American Institute of Architects

$\mathrm{A} / \mathrm{V}$

audio/visual

BGSF

building gross square feet

CAV

Constant Air Volume

CBECS Commercial Building Energy Consumption Survey

Cfm

cubic feet per minute

CGSF component gross square feet

CHW chilled water

CSOP Court Statistics Project

DGSF departmental gross square feet

DOE Department of Energy

ESPC Energy Savings Performance Contract

FEMP Federal Energy Management Program

GSA General Service Administration

GSF gross square feet

HVAC heating, ventilation, and air conditioning

HW hot water

IECC International Energy Conservation Code

IGA investment grade audit

JCUS The Judicial Conference of the United States

JFR Justice Facilities Review

NCSC National Center for State Courts

NSF net square feet

ORNL Oak Ridge National Laboratory

PNNL Pacific Northwest National Laboratory

RSF rentable square feet

SCO State Court Organization

SHW service hot water

EIA US Energy Information Administration

USCDG US Courts Design Guide

USF usable square feet

VAV variable air volume

WBDG whole-building design guide

WWR window-to-wall area ratio 



\section{EXECUTIVE SUMMARY}

As part of the Department of Energy's support of ANSI/ASHRAE/IES Standard 90.1 and the International Energy Conservation Code, researchers at Pacific Northwest National Laboratory apply a suite of prototype buildings covering $80 \%$ of the commercial building floor area in the United States for new construction. Efforts have begun to cover $90 \%$ of the commercial building floor area in the United States by developing prototype models for additional building types that include supermarket, laboratory, place of worship, public order and safety, and public assembly. "Courthouse" is a subcategory under the "Public Order and Safety" building type category defined by the Commercial Buildings Energy Consumption Survey (CBECS); other subcategories include police station, fire station, and detention and correctional facilities (i.e., jail, reformatory, or penitentiary).

According to the 2012 CBECS, courthouses occupy a total of 436 million $\mathrm{ft}^{2}$ of floor space, $0.5 \%$ of the total US commercial floor space, as compared to the fast-food (0.35\%), grocery store or food market $(0.88 \%)$, and restaurant or cafeteria (1.2\%) building types already included in the Commercial Prototype Building Model suite. The courthouse is a large building type with a mean floor area of $69,400 \mathrm{ft}^{2}$ compared to an average of $15,700 \mathrm{ft}^{2}$ for all commercial buildings) with an average fuel consumption intensity of $94.7 \mathrm{kBtu} / \mathrm{sq} \mathrm{ft}$ compared to an average of $80 \mathrm{kBtu} / \mathrm{ft}^{2}$ for all commercial buildings. Courthouses range in size from 1,000 to $1,000,000 \mathrm{ft}^{2}$ and from 1 to 100 courtrooms. Small courthouses represent a majority of courthouse buildings, but a small fraction of total courthouse floor area. Space and operation of courthouses vary depending on the court type and jurisdiction (e.g. federal court vs. state court; district court vs. appellate court; general jurisdiction court vs. specialty and limited jurisdiction court).

The US Courts Design Guide categorizes courthouse based on the number of courtrooms, small for up to 5 courtrooms, medium for 6-12 courtrooms and large for more than 12 courtrooms. Based on the number of floors, it designates courthouses as low-rise (up to 4 floors above grade), mid-rise (5-9 floors above grade) and high-rise (10 or more floors above grade). Informed by data from over 550 courthouses, we recommend a general jurisdiction trial, small, low-rise courthouse for the prototype model with 4 courtrooms and a 69,324 $\mathrm{ft}^{2}$ floor area, distributed on three floors including a basement. This was chosen to represent the most common courthouse in terms of number of buildings but provide additional information in this report to guide modification to represent largest floor space. The footprint of the building was determined by developing the floor plan of the court floor based on the space, location, and adjacency requirements specified in courtroom design guides. The remaining functional spaces were then housed on other levels inside the building footprint. The construction, occupancy and systems characteristics were determined from a variety of resources.

Oak Ridge National Laboratory used building design guides, databases, and documented courthouse projects, supplemented by personal communication with courthouse facility planning and design experts, to systematically conduct research on the courthouse building and system characteristics. This report documents this research and reports the building and system characteristics necessary for developing a Courthouse prototype building energy model to be included in the Commercial Building Prototype Model suite. 


\section{INTRODUCTION}

\subsection{BACKGROUND}

The US Department of Energy (DOE) supports the development of commercial building energy codes and standards by participating in industry review and update processes and providing technical analyses to support both published model codes and potential changes (Building Energy Codes Program 2016). As part of DOE's support of ANSI/ASHRAE/IES ${ }^{1}$ Standard 90.1 and the International Energy Conservation Code (IECC), researchers at Pacific Northwest National Laboratory (PNNL) apply a suite of prototype buildings covering $80 \%$ of the commercial building floor area in the United States for new construction. This includes mid- to high-rise residential buildings and covers all US climate zones. The prototype models include 16 commercial building types in 17 climate locations (across all 8 US climate zones) for recent editions (2004, 2007, 2010, and 2013) of Standard 90.1 and recent editions (2006, 2009, 2012, and 2015) of the IECC. The current combination results in an overall set of 2,176 total building models in EnergyPlus $^{\mathrm{TM}}$ Version 8.0 (Building Energy Codes Program 2016).

To determine the building types and prioritize the model development for this suite, the Commercial Building Energy Consumption Survey (CBECS) building type subcategories (EIA 2016) and relevant survey data were used. For the selected building types, building and system characteristics were researched using a variety of resources to develop building descriptions, thermal zone internal loads, schedules, and other key modeling input information, necessary to create a canonical building energy model (Deru et al. 2011).

Continuous efforts are needed to make modification to the commercial prototype building models as Standard 90.1 and the IECC evolve (Building Energy Codes Program 2016). Recent efforts are focusing also on being able to create the EnergyPlus model ${ }^{2}$ through OpenStudio ${ }^{3}$. Parallel efforts have begun to expand the prototype building suite to cover $90 \%$ of the commercial building floor area in the United States, by developing prototype models for additional building types. A list of new building models is prioritized through discussions among DOE, ASHRAE, American Institute of Architects (AIA), and the national laboratories. The building type categories to be incorporated in the prototype suite include supermarket, laboratory, place of worship, public order and safety, and public assembly.

The courthouse building type was chosen as the first prototype building to add since Oak Ridge National Laboratory (ORNL) has ready access to data on several federal courthouses that are undergoing energy retrofits through Energy Savings Performance Contracts (ESPCs) under DOE's Federal Energy Management Program (FEMP). Additional resources including building design guides, databases and documented courthouse projects, supplemented by personal communication with courthouse facility planning and design experts were used to systematically conduct research on the courthouse building and characteristics necessary for a full-fledged building energy model.

This report documents the research conducted for the courthouse building type, reports building and system characteristics, and plans to implement a Courthouse building energy model to be included in the Commercial Building Prototype Models suite. Chapter 1 of this document provides a background of the project and details resources for courthouse information. Chapter 2 provides an overview of US courthouses and presents relevant findings from design guides. Chapter 3 presents findings from building

\footnotetext{
${ }^{1}$ American National Standards Institute/American Society of Heating, Refrigerating and Air-Conditioning Engineers/Illuminating Engineering Society

${ }^{2}$ https://energy.gov/eere/buildings/downloads/energyplus-0

${ }^{3}$ https://github.com/NREL/openstudio-standards
} 
databases on courthouses and documented courthouse projects. Chapter 4 presents recommendations for the building and system characteristics required to develop the prototype courthouse energy model.

\subsection{RESOURCES}

\subsubsection{Design Guides}

Several courthouse design guides were reviewed to provide functional program requirements, adjacency relationships, and performance criteria for related building systems. Key resources include:

- General design guides

$\circ \quad$ Phillips and Griebel (2003)

○ Hardenbergh et al. (1991)

$\circ \quad$ The Virtual Courthouse (n.d.)

○ Wong (2001)

○ The American Courthouse (1973)

- Design guides for federal courts

- US Courts Design Guide (USCDG; 2007)

- US General Services Administration (GSA; 2017a, n.d.)

$\circ \quad$ Whole-building design guide (WBDG; 2016a, 2016b, 2016c)

- Thacker (2017)

- Design guides for state courts

- California: California Trial Court Facilities Standards (draft) (2011)

- Illinois: Minimum Courtroom Standards in the State of Illinois (2011)

- Kentucky: Kentucky Court Facilities Criteria (2007), Kentucky Court Facilities Design Guide (2007)

- Michigan: The Michigan Courthouse (2000)

○ Nebraska: Nebraska Courts Facility Planning (1999)

- New York: Guidelines for New York State Court Facilities (2009)

- Utah: Utah Judicial Facility Design Standards (2016)

○ Virginia: Hardenbergh (2015)

In addition, supplemental sources were reviewed to determine space requirements for security (Griebel and Phillips 2001), circulation (GSA 2012), and detention area (Kimme \& Associates, Inc. 1998).

\subsubsection{Courthouse Operation}

In order to determine the function and schedule of different spaces in a courthouse, courthouse operation was reviewed from resources from the American Bar Association (ABA 2017), the US Department of Justice (Offices of the US Attorneys 2017) and the US Courts (Administrative Office of the US Courts 2016, US Courts 2017).

\subsubsection{Database of Courthouses}

2012 CBECS data: The 2012 CBECS public use microdata (EIA 2015) includes a detailed set of data for a statistical sample of 26 courthouses ranging from 1,300 to 800,000 $\mathrm{ft}^{2}$. Combined with sample weights, they represent 6,278 courthouses in the United States. This dataset provides a range of information including general building characteristics (e.g. building square footage, number of floors, glass area, and floor height); construction characteristics; schedules of use; and heating, ventilation, and air-conditioning (HVAC) system characteristics. 
1992 CBECS data: The 1992 CBECS public use microdata (EIA 1996) includes a detailed set of data for a statistical sample of 83 buildings under public order and safety. This dataset is used to supplement information not available in the 2012 CBECS database (e.g. building aspect ratio).

Court Statistics Project DataViewer: The Court Statistics Project provides an interactive tool that serves caseload data and population served by state courts (Schauffler et al. 2017). A rough correlation is found between the number of caseloads and population in order to inform a common number of courtrooms.

State Court Organization App: This interactive, web-based application presents detailed comparative data about how state trial and appellate courts are organized and administered (Strickland et al. 2017). It includes a complete list of court types established in each state, which we use to determine the type of court the prototype model should represent.

U.S. General Services Administration (GSA) Portfolio Data: GSA manages leased and owned assets of the federal government covering a variety of facility types including office buildings, courthouses, land ports of entry, and warehouses. The Office of Portfolio Management at GSA maintains a portfolio of these assets. According to the FY 2016 State of the Portfolio Snapshot (GSA 2016), federal courthouses constitute rentable square feet (RSF) of 29.7 million sq $\mathrm{ft}$ as owned assets and 1.3 million sq $\mathrm{ft}$ in leased assets (i.e., a total of 31 million sq ft).

A subset of GSA Portfolio Data on courthouses (GSA 2017b) was obtained that lists 158 federal buildings covering 34.65 million building gross square feet (BGSF). Federal courthouse buildings may include a post office or other federal offices. Excluding all non-court functions, covered parking, common spaces (lobbies, corridors, mechanical and electrical service areas, toilet, janitorial, loading docks), vertical penetrations (stairs, elevators, service shafts, etc.), and exterior walls, these buildings comprise 17.23 million sq ft of total court usable square feet (USF). This data helped investigate the area statistics in federal courthouses.

\subsubsection{Courthouse Projects}

Courthouse Retrospective book series: The National Center for State Courts (NCSC) publishes three volumes of a series that chronicles the major courthouse design trends of three decades 1980-1991 (Hardenbergh 1992), 1991-2001 (Hardenbergh and Phillips 2001), and 2001-2010 (Yeh et al. 2010a). Each volume is a collection of several courthouse projects featuring a full range of court jurisdictions, including federal, state, local, and international courts, and illustrates architectural innovations and solutions sought in addressing the evolving judicial needs of the decades. Collectively, there are 236 courthouse projects included in these volumes. Projects included in each publication were submitted by architectural design firms in response to call for entries by NCSC and selected by a jury composed of justice system professional and courts planning and design professionals. Yeh et al. (2010b) summarizes the evolving courthouse design issues documented in these volumes.

These publications provide an overview description and technical data for each project including the building square footage, number of courtrooms, typical court floor plans, photos of the inside and/or outside of the building, and a discussion on the overall design trend including the courtroom design, massing strategies, and architectural style reflected in the façade and use of materials.

Justice Facilities Review archive: The Justice Facilities Review (JFR) is an annual publication by the American Institute of Architects (AIA), which documents best practices in planning and design for Justice Architecture. Publications for the last 21 years (1997-2016) are available online (AIA 2017). Each publication includes up to 12 courthouse projects, submitted by architectural design firms and selected by 
a jury composed of justice system professional and courts planning and design professionals. Many projects included in these publications overlap with those included in the Courthouse Retrospective series.

Investment grade audit (IGA) documentation of federal courthouses ${ }^{4}$ : Under FEMP ESPCs, 31 awarded projects in 2010 included federal courthouses in four states including Arkansas, Louisiana, New Mexico, and Texas. The IGA documentation of these projects provides information on general building characteristics, construction, occupancy, detailed information on HVAC systems and controls, and energy and water use.

\subsubsection{Personal Communication}

Personal communication with architects, facility design, and planning experts specialized in courthouses helped the team identify useful resources; understand courthouse operations, space requirements, and occupancy characteristics; and develop area programming and floor plans.

\subsection{COURTHOUSE VERSUS OTHER BUILDINGS IN CBECS}

According to CBECS Building Type Definitions (EIA n.d., 2016), courthouse is a subcategory under the "Public Order and Safety" building type category; other sub-categories include police station/fire station and jail, reformatory, or penitentiary (i.e., detention or correctional facilities). To gauge courthouses' share of the existing US building stock and the energy used in the buildings, the 2012 CBECS data (EIA 2016) for courthouse is compared with other building types included in the Commercial Prototype Building Models suite (Building Energy Codes Program 2016) .

\subsubsection{Percent of Total Commercial Building Floor Space}

The 2012 CBECS data represents 6,278 courthouses in the United States. Courthouses occupy a total of 436 million sq $\mathrm{ft}$ of floor space or $0.5 \%$ of the total floor space in all commercial buildings in the United States, which is of the same order as fast food $(0.35 \%)$, grocery store or food market $(0.88 \%)$, and restaurant or cafeteria (1.2\%) building type sub-categories currently included in the Commercial Prototype Building Model suite (highlighted as red bars in Figure 1).

\footnotetext{
${ }^{4}$ IGA documentation under the FEMP ESPprogram contains findings that are deemed business sensitive by the project developers and therefore are not publicly available.

${ }^{5}$ See Appendix A for 2012 CBECS data tables listing all building activity subcategories (EIA 2016).
} 


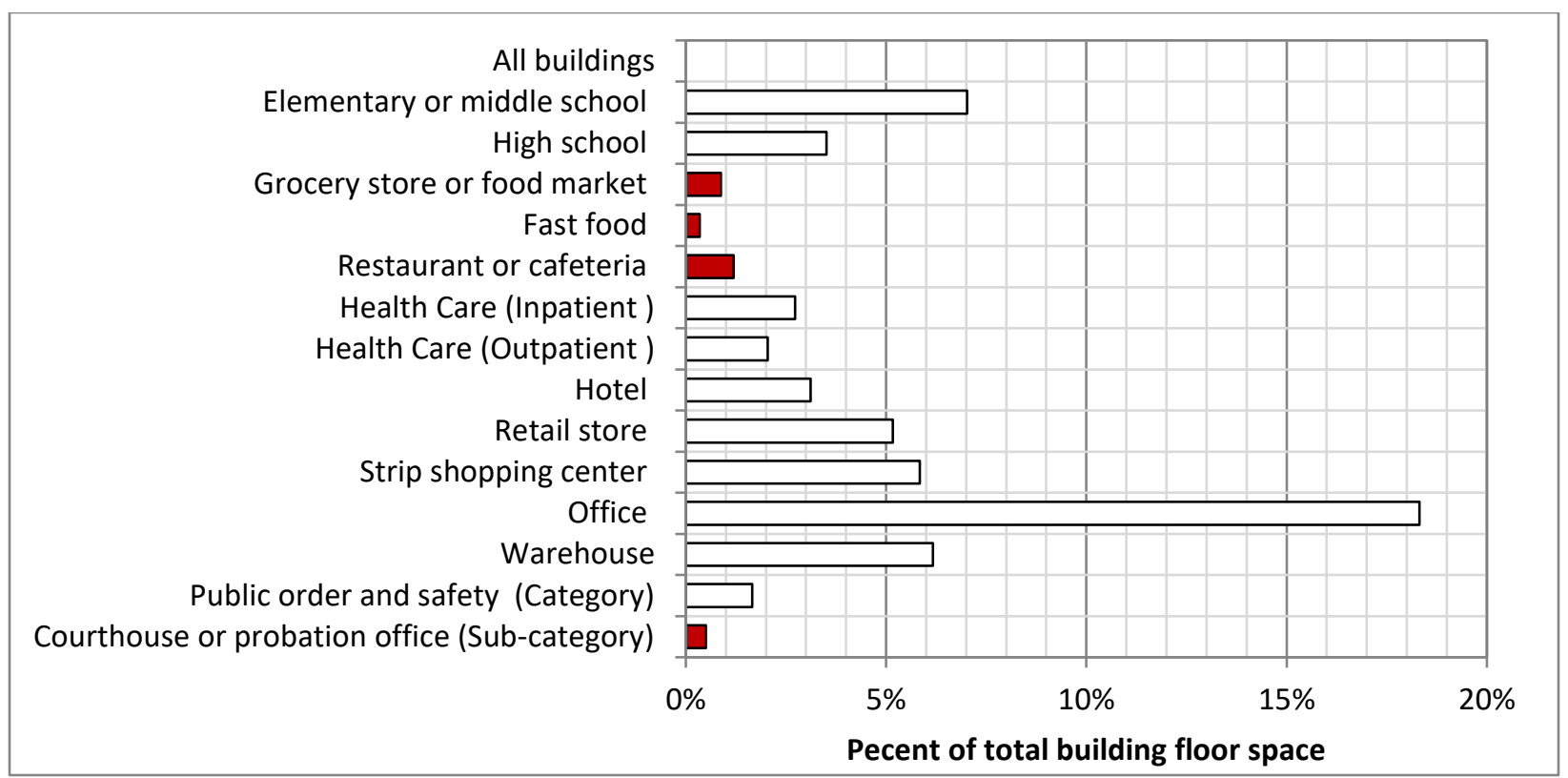

Figure 1. Percent of total building floor space for courthouses compared to other buildings currently in the Commercial Prototype Building Model suite. (Source: EIA 2015)

\subsubsection{Building Floor Area}

Courthouse is a large building type, similar to high schools and hotels with a mean floor area of 69,400 sq $\mathrm{ft}$ compared to 17,200 sq ft per building for the parent "Public Order and Safety" category, 15,800 for office, and 15,700 sq ft for all commercial buildings (all highlighted as red bars in Figure 2).

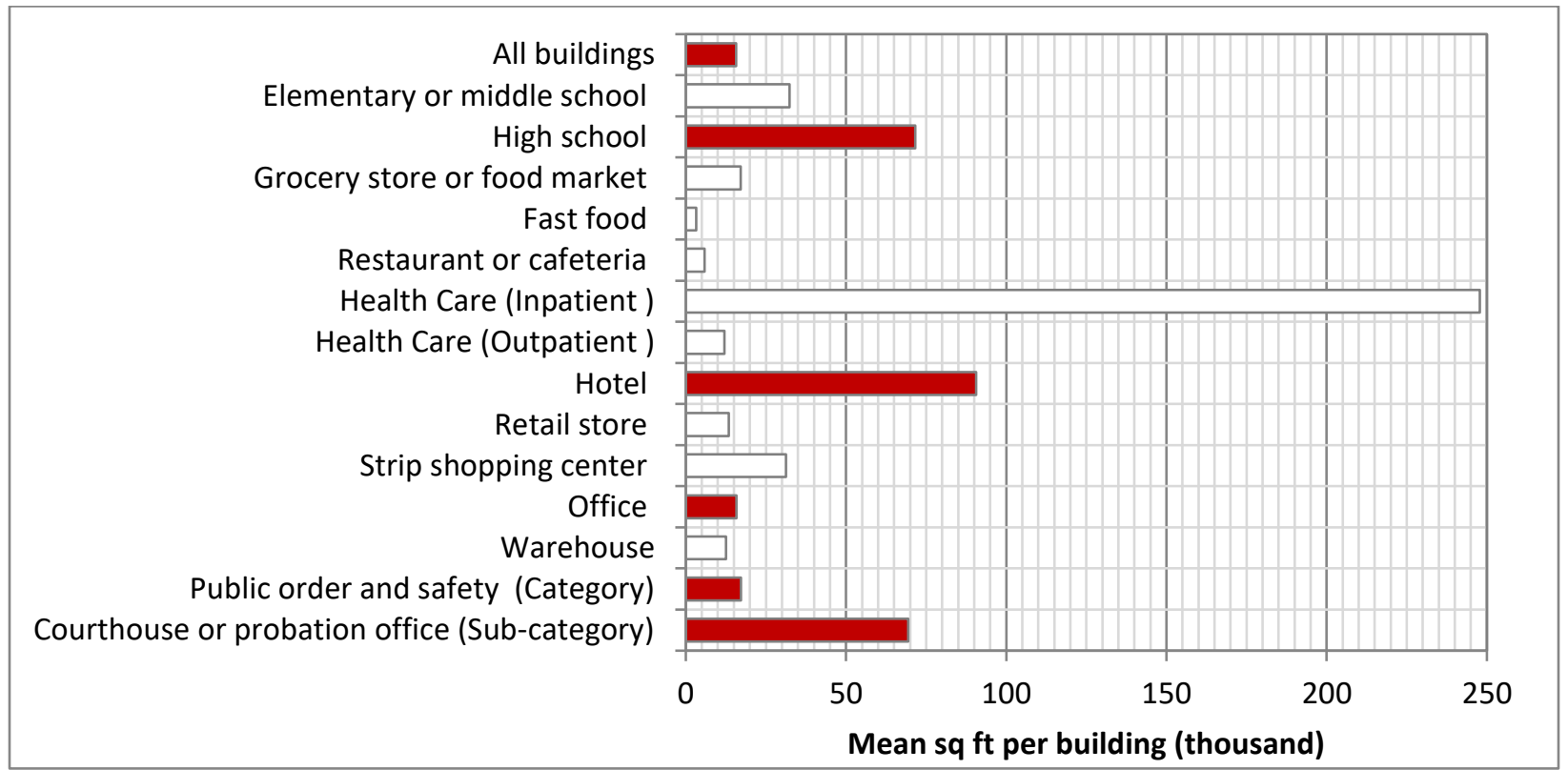

Figure 2. Building floor area for courthouse compared to other buildings. (Source: EIA 2015) 


\subsubsection{Fuel Consumption Intensity}

Courthouses are among the smaller fuel consumption intensity building types with a narrow range of variation and an average of $94.7 \mathrm{kBtu} / \mathrm{sq} \mathrm{ft}$, next to $77.8 \mathrm{kBtu} / \mathrm{sq} \mathrm{ft}$ for office and $80 \mathrm{kBtu} / \mathrm{sq} \mathrm{ft}$ for all buildings (Figure 3).

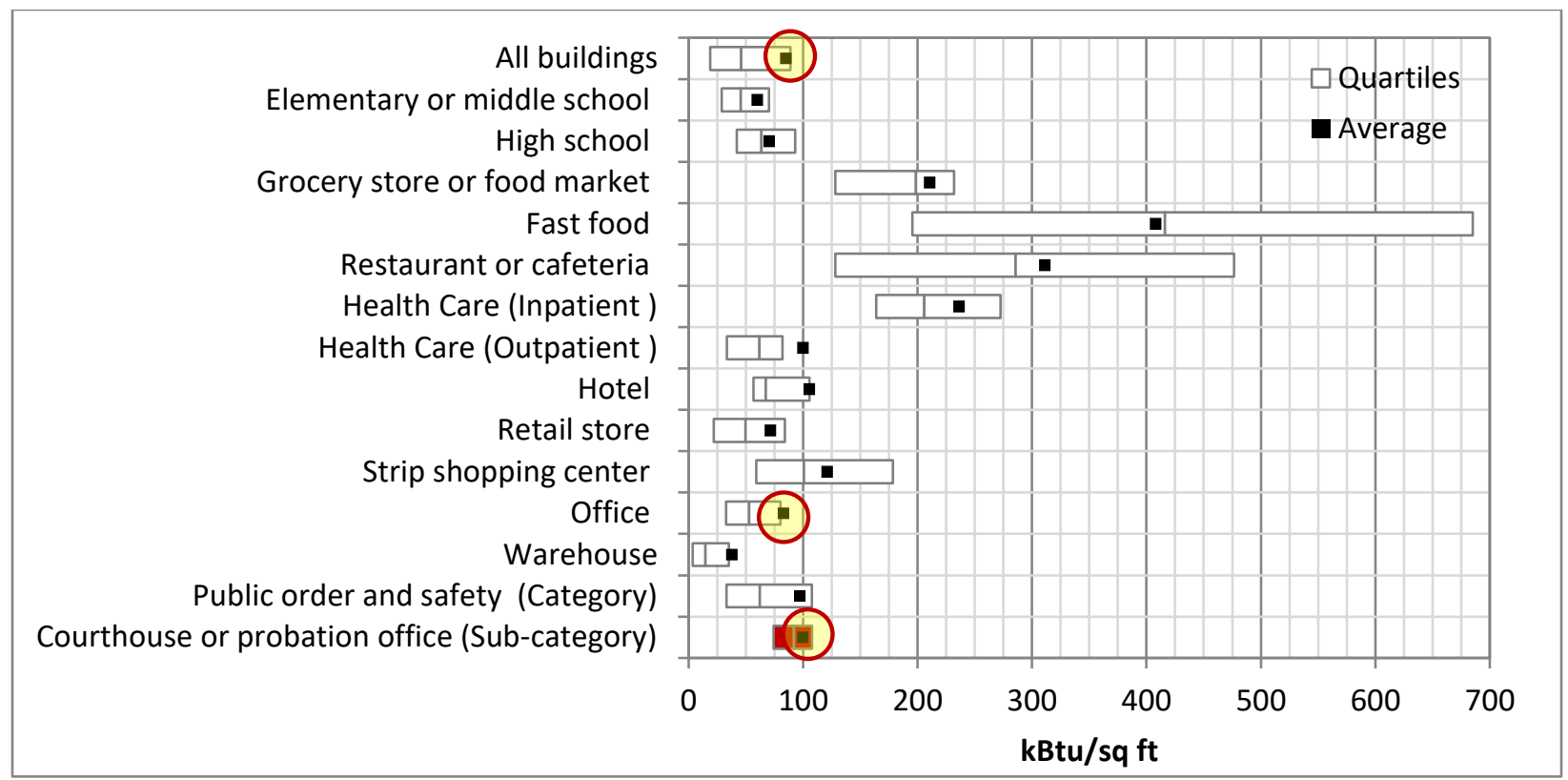

Figure 3. Fuel consumption intensity statistics for courthouse versus other buildings. (Source: EIA 2015)

Figure 4 plots the fuel consumption intensity versus mean floor area of courthouses and other buildings. The clusters indicate building types that are similar in terms of average size and energy use. Courthouses are dissimilar to most buildings.

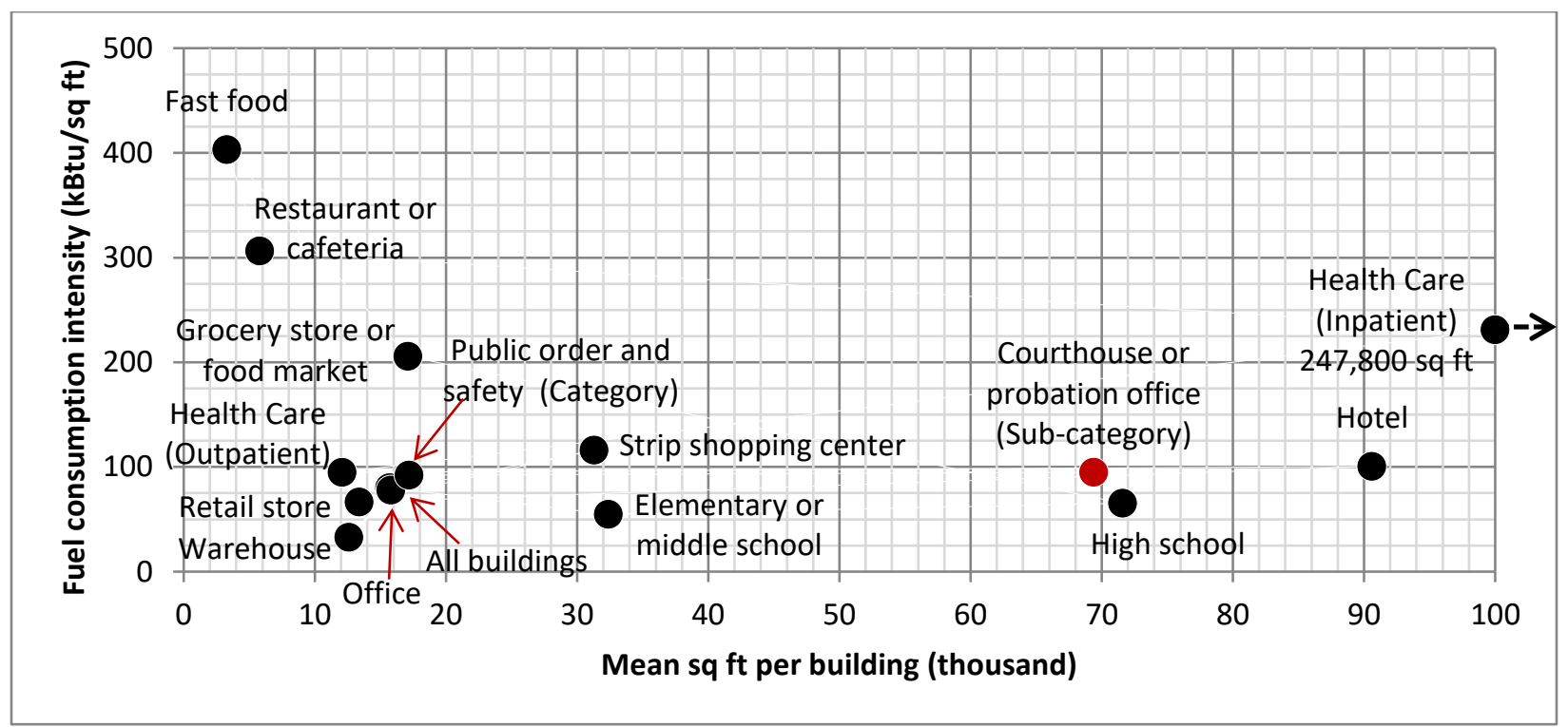

Figure 4. Fuel consumption intensity versus mean floor area for courthouse versus other buildings.

(Source: EIA 2015) 


\section{OVERVIEW OF COURTHOUSES IN THE UNITED STATES}

Characteristics of courthouses in the United States vary widely in terms of court type, operations, and size. Prior to researching the building and system characteristics for courthouses, it is important to recognize the types, operations and statistics of the courts that comprise the US court system. This can be used to prioritize and define a narrative for the prototype model in order to represent most, if not all, types of courts. Understanding court operations is important to accurately defining the space types, usage, occupancy characteristics, and schedule of use for those spaces.

\subsection{US COURT SYSTEM}

The US court system has many court systems: 50 state court systems, 3 territorial court systems, and a federal court system. Each state has at least two distinct court systems with its own multi-tiered structures and procedures. Legal cases begin in a lower court and can work their way up to a higher court. State and federal courts are generally divided into three layers: (i) trial courts, the lowest tier where case starts, (ii) intermediate (appellate) courts, where most appeals are first heard; and (iii) courts of last resort (usually called supreme courts), which hear further appeals and have final authority in the cases they hear. Some cases initiated in a state court system ultimately end up in the federal court system. (Figure 5)
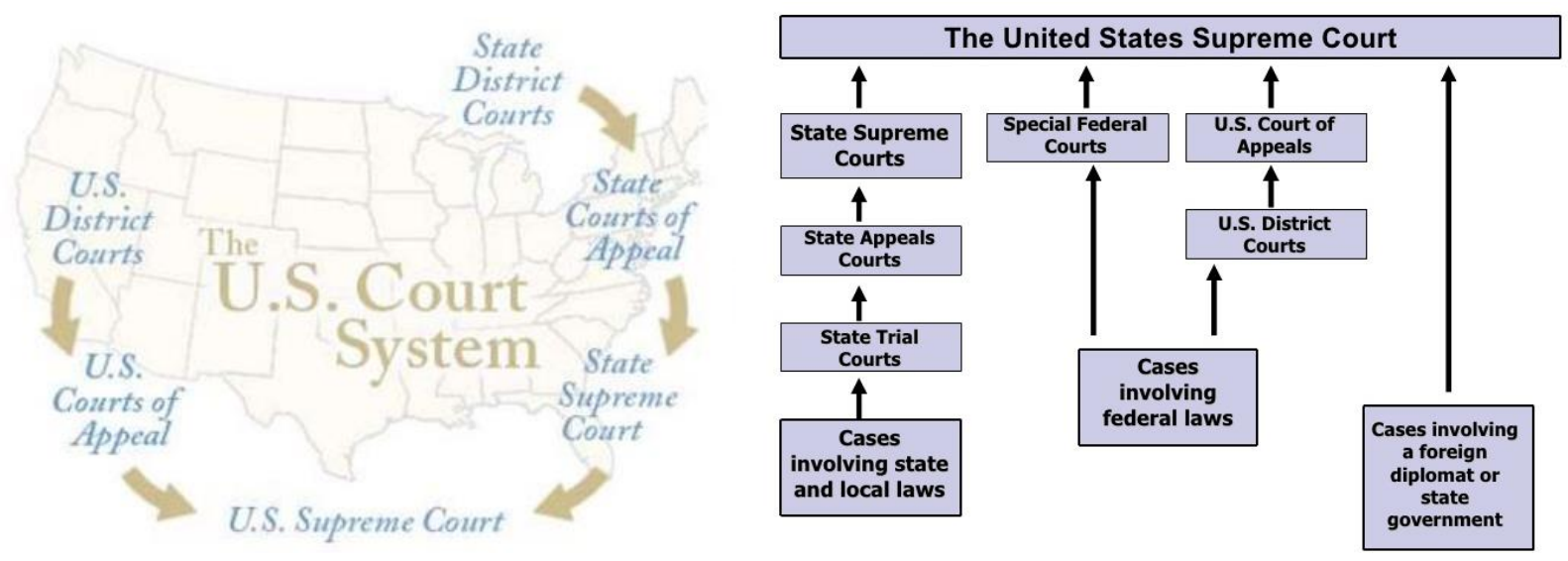

Figure 5. The US court system. (Source: SlideShare: Organization of US Court System)

\subsubsection{State Courts}

Most legal issues are resolved in state trial courts, the courts at the lowest tier in a state's court system. Depending on the specific structure of the state's court system, trial courts may be city or municipal courts, justice of the peace courts, county or circuit courts, or even regional trial courts. The next tier up in the typical state court system is the appellate courts. Every state has a court of last resort, generally called the supreme court. According to the State Court Organization (2017), there are 15,679 district courts (trial courts), 95 appellate courts (Court of Appeal), and 57 supreme courts in the United States. There are differences in the design and operations due to a variety of reasons including differences in court structure, case definitions and counting practices, court rules, statutes, or terminology (Courts Statistics Project 2013).

\subsubsection{Federal Courts}

Most of the federal court system is divided into districts and circuits which have three main levels: (i) district courts (the trial court), (ii) circuit courts which are the first level of appeal, and (iii) the Supreme Court of the United States, the final level of appeal in the federal system. There are 94 district courts, 13 
circuit courts, and one Supreme Court ${ }^{6}$ (US Courts 2017) (Figure 6). There are 456 meeting places for the 94 districts where Court for the District is held.

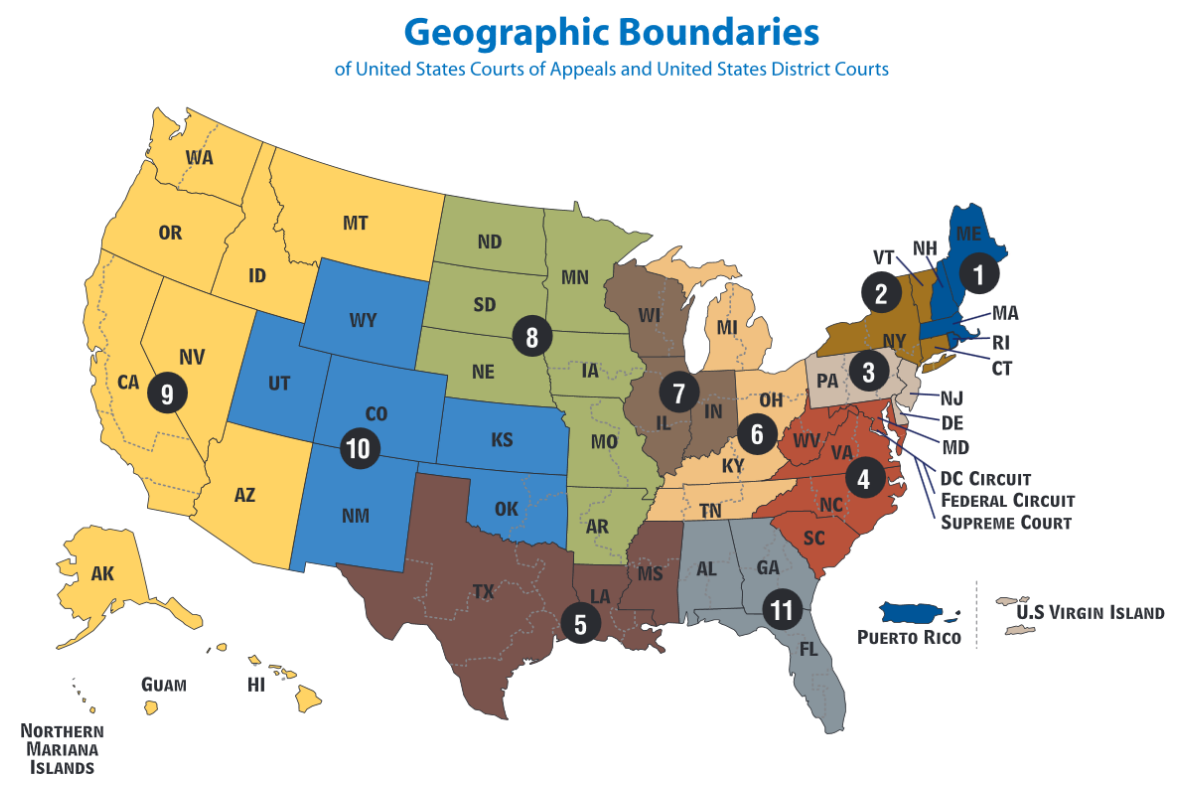

Figure 6. Geographic boundaries of federal courts (courts of appeal and district courts).

(Source: US Courts 2017)

\section{Difference between Federal and State Courts}

- State courts handle a wide range of case types ranging from traffic violations to criminal cases. There is a large number of very small state courthouses (less than 5,000 sq ft gross floor area). The minimum USF for a federal courthouse is 4,236 sq ft (GSA 2017b).

- The courtrooms, public spaces, and judges' chambers are larger in federal courthouses. Thus, the ratio of floor area to number of courtrooms is higher in federal courthouses.

- Federal courthouses, in most cases, are in multi-tenant buildings that may be occupied by an US post office and other federal offices. US Marshals Service occupies a significant part of federal courthouses.

\section{Difference between District Trial Courts and Court of Appeal}

Trial courts may involve a jury requiring larger courtrooms to accommodate space for the jury, a jury assembly room, multiple jury deliberation rooms, attorney client/witness waiting rooms, detention area, and secured circulation for in-custody defendants. The courts of appeal do not take trial cases, and therefore do not require these spaces.

\footnotetext{
${ }^{6}$ There are 94 federal districts (including 89 federal districts in the 50 states and one district each in Puerto Rico, the Virgin Islands, the District of Columbia, Guam, and the Northern Mariana Islands) and 13 circuits (including 11 circuits consisting of more than one district, a circuit for the District of Columbia, and a Federal Circuit).
} 


\subsection{FUNCTIONAL SPACES}

Courthouses are used by a variety of people including judges, attorneys, witnesses, victims, in-custody defendants, clerks, other employees, outside social agencies, the press, and the general public. The characteristic spaces in a courthouse include courtrooms, judge's suites, offices, lobby, waiting areas, and secured parking or garage (for judges, court officers, and others with high security clearance). Trial courthouses additionally require spaces for jury operation. The location, size, and occupancy of these spaces are based on the following requirements (Don Hardenbergh, February 15, 2017):

- Courtrooms: separate access from public circulation, private circulation and secured circulation

○ Court support: audio/visual (A/V) equipment room, evidence and exhibit storage rooms (in private circulation areas),

○ Courtroom waiting

- Attorney-client/witness waiting rooms: two per courtroom

- Sound lock vestibule: between courtroom and waiting area

- Judges suite: Courtroom floors or dedicated floor(s)

○ Judge's chamber with a toilet

- Conference room

- Staff

○ Support

- Court clerk

$\bigcirc \quad$ Open office: staff area, counters facing queuing area

- Clerk office (private)

- Court administration

- In-custody Defendant holding

○ Central: Basement or lower floor, entrance through sally port, a central control area, equipment loads, connection to secure elevators.

○ Distributed: on courtroom floors usually serving pairs of courtrooms.

- Jury spaces

$\circ$ Jury assembly area: first floor, seating facing A/V or podium, lounge, toilets

- Jury deliberation suite: located on courtroom floors, access from private circulation, with two toilets, sound lock vestibule

- Law library (optional)

- Court reporters

- Public support

○ Lobby: First floor, through a security screening area

$\circ$ Vending/snack bar

- Building support:

○ Mail room

- Maintenance area

○ Storage

- Mechanical/electrical room

- Building entrances:

$\circ \quad$ A shared staff and public entrance;

- A separate entrance for judges and bench officers (from secured parking)

$\circ$ A loading zone for delivery vehicles

- Circulation:

○ Public circulation: public stairs and elevators; corridors

- Private circulation: separate corridors for staff, judges, and jury; separate elevator and stairs for judges from secured parking to judge's chambers 
- Secured circulation: corridors wide enough to allow 3 people in one direction and one from the opposite direction; detention elevators

- Parking:

○ Secure parking: for judges, court officers, and others with high security clearance (adjacent to or within the courthouse)

○ General Parking: for all other courthouse users; 2-4 spaces per 1,000 BGSF

\subsection{KEY OPERATIONAL AND ORGANIZATIONAL CONCEPTS}

Courthouses have several unique characteristics which differentiate them from commercial office buildings and government administration buildings.

\subsubsection{Grossing and Efficiency Factors}

According to The Virtual Courthouse (n.d.), courthouses have relatively less space efficiency compared to typical commercial office buildings due to special volume, circulation and security needs.

- Net square feet (NSF) includes space required for a particular function, exclusive of interior wall or circulation space around the functional area. NSF for a courthouse is typically $57-65 \%$ compared to $66-70 \%$ in a typical commercial office building.

- Departmental gross square feet (DGSF) ${ }^{7}$ equals NSF plus circulation factor that includes space for interior walls and partitions, internal corridors, and circulation among functional components. DGSF for a courthouse should be 75-85\% (1.3-1.4 times NSF). DGSF for administrative purposes is similar to those in commercial offices or govt. administration buildings. DGSF of courtrooms and holding facilities typically require considerably more internal circulation.

- Building gross square feet (BGSF) includes basic core functions to link various functional departments and transport people among floors (corridors, public elevators and elevator lobbies, private and secure elevators, stairs, mechanical electrical and plumbing chases, public toilet facilities, and the exterior walls of the building). Main lobbies, bulk storage areas and major mechanical systems might be treated as net assignable spaces. Considering BGSF to be $100 \%$, in a typical courthouse (1.18-1.25 times DGSF).

Usable area typically accounts for 67\% of the total gross area of court facilities (USCDG 2007). California Trial Court Facilities Standards (2011) recommends BGSF of 9,000-14,000 per courtroom, NSF of $57-65 \%$ of BGSF, and CGSF (or DGSF) of 71-74\% of BGSF.

\subsubsection{Circulation}

According to The Virtual Courthouse (n.d.), the courthouse circulation system consists of three separate and distinct paths of movement for the public, court professionals (judiciary and staff), and in-custody accused persons (Figure 7 and Figure 8). In addition, there are interfaces between public and private circulation through screening or security, and secondary circulation for service staff.

- Public circulation provides access from main building entrances to the various functional areas of the building, such as the main lobby, corridors, public elevators and escalators, public restrooms, law library, waiting areas, snack bars, clerk of court counters, and reception areas.

\footnotetext{
${ }^{7}$ In GSA Portfolio Data, DGSF is equivalent to USF or usable square feet. In California Trial Court Facilities Standards (2011), DGSF is equivalent to CGSF or component square feet.
} 
Users of the public circulation include general public, attorneys, clients, witnesses, jurors (before sequestration), courthouse staff, prosecutors, lawyers, police officers, witnesses, reporters, accused persons who are not in custody, members of the public, persons with business at the clerks' offices, and courtroom spectators.

- Private circulation provides controlled access to particular courthouse users and is not easily or routinely used by the general public. It permits the movement of judges and other trial-related court personnel between chambers and courtrooms, and the movement of sequestered jurors between courtrooms and jury deliberation rooms, without uncontrolled interaction with other courthouse users.

- Secure circulation provides for the movement of defendants in custody. Access to the building through a secure vehicular or pedestrian sally port, a secure central holding and staging area before being escorted to individual courtrooms as needed. Small holding units directly adjacent to the court rooms, secure elevators for circulation from the central holding area to the individual courtrooms. The only quasi-public interface that might occur would involve meetings with defense attorneys in holding areas. This interface may be addressed by allowing attorneys to meet with clients at either the central holding areas or the individual holding facilities adjacent to the courtrooms. It must be physically separate from all non-secure spaces and circulation systems in the courthouse.

- Secondary Circulation: There is generally a secondary circulation zone for staff and building services, especially, in larger courthouses. This zone is largely contained within the space envelope of the staff areas of the building. The integrity of this zone relies on controlled access between public and private circulation. Included in the service zone are all those spaces that serve as building support areas for the courthouse, such as the receiving dock, program and building storage areas, building maintenance areas, and the mechanical spaces that are accessed in a secondary circulation zone. The entrances to the building through the receiving dock must be secure and access must be controlled. Entry from public circulation into these areas should be via a door with controlled access.

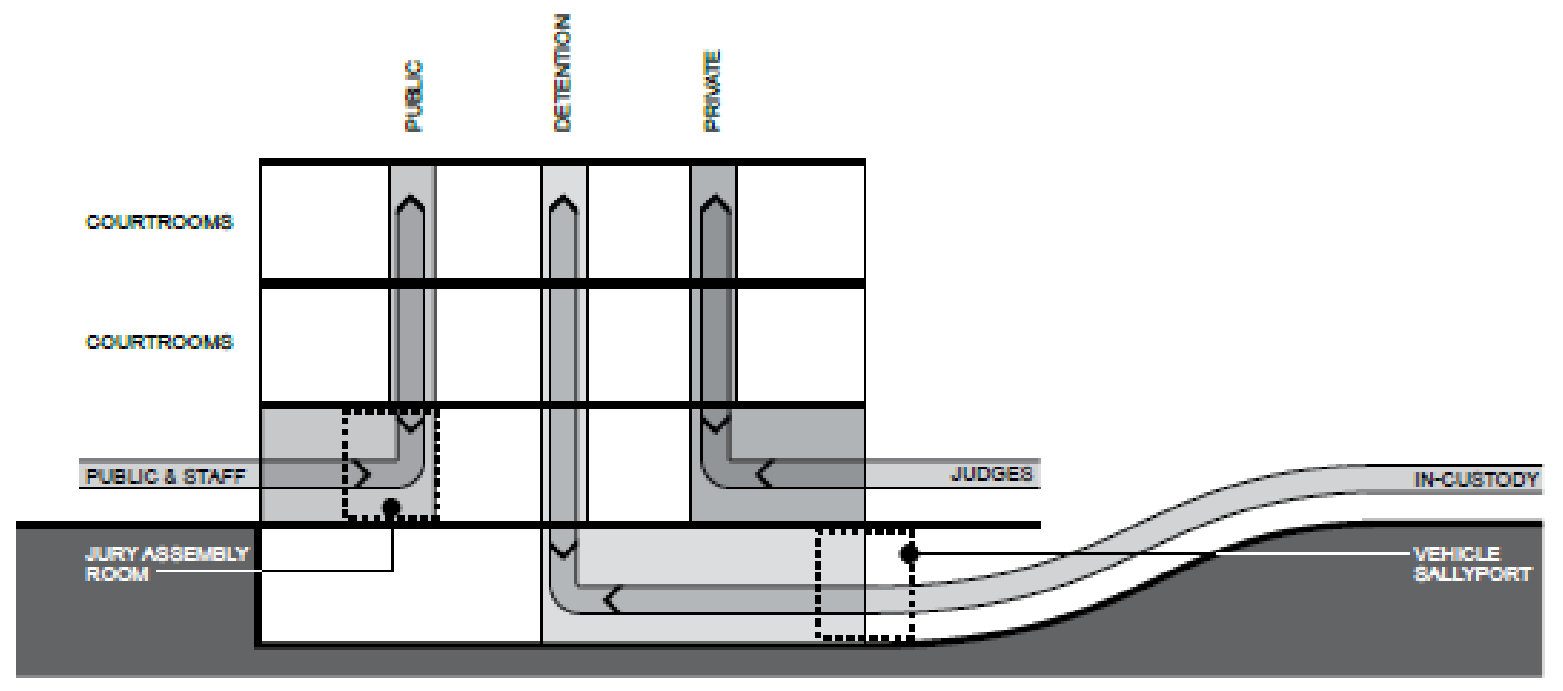

Figure 7. Section showing three part circulation system.

(Source: California Trial Court Facilities Standards 2011) 

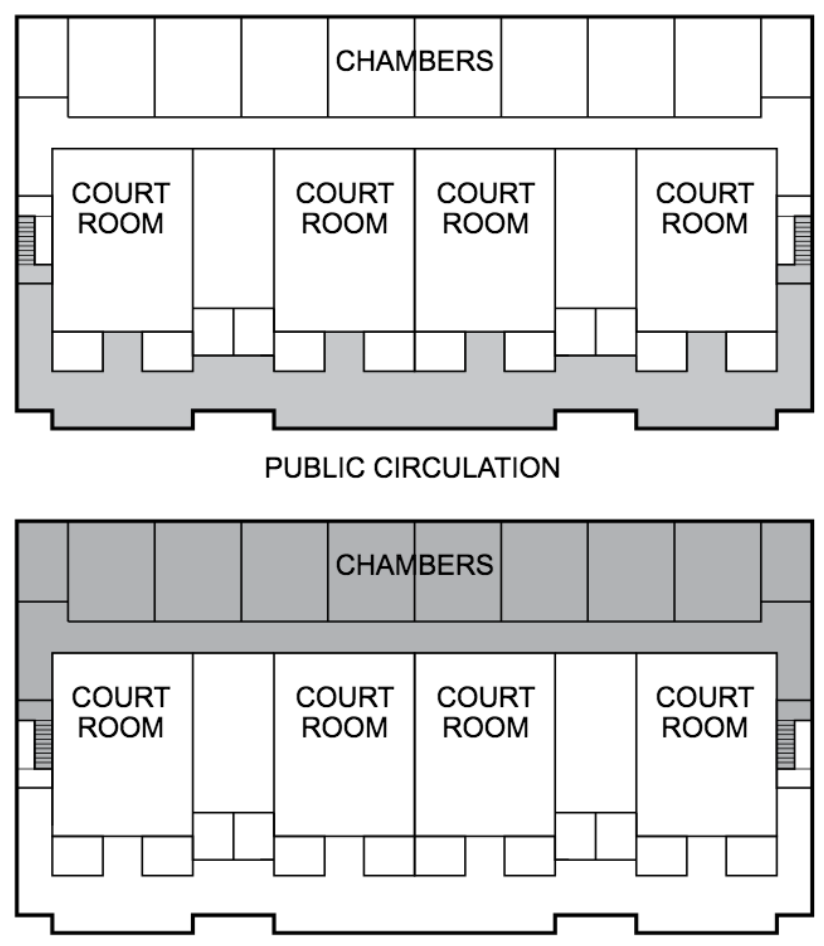

PRIVATE CIRCULATION

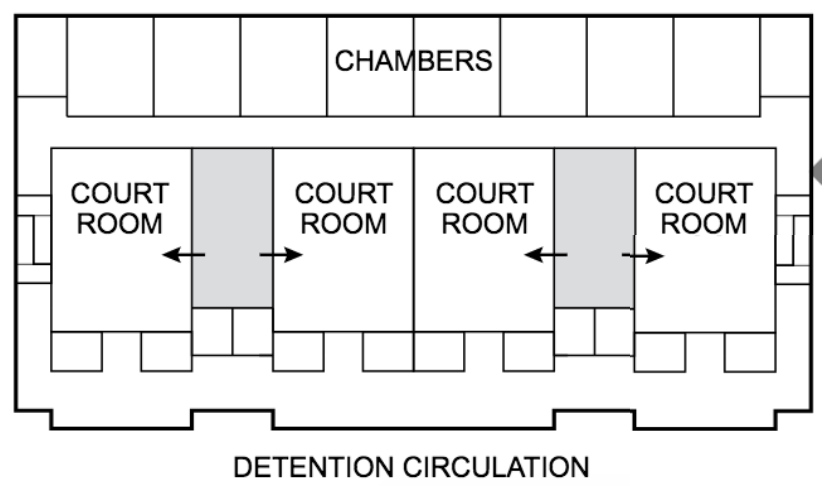

Figure 8. Court floor plan showing three-part circulation system.

(Source: California Trial Court Facilities Standards 2011)

\subsubsection{Adjacency, Stacking and Blocking}

Figure 9 shows the stacking scheme of different floors in a low-rise and a high-rise courthouse. In a courthouse, the layout is typically different on lower floors. High-volume functions are located on the lower floors and near the lobby. These include central court office areas (e.g. clerks and jury assembly). Functions that require after-hours access are typically located on the first floor where public entrance is through a screening area with a metal detector. Courtrooms are clustered on the higher floor(s), with shared support spaces. Judges' chambers and offices of judiciary staff are located on courtroom floors or clustered on a dedicated floor. In trial courthouses, a central detention area for in-custody defendants is located on the lower floor and accessed through a sally port. The in-custody defendants are brought to the courtrooms during a hearing through an intermediate detention area via secured elevators. 

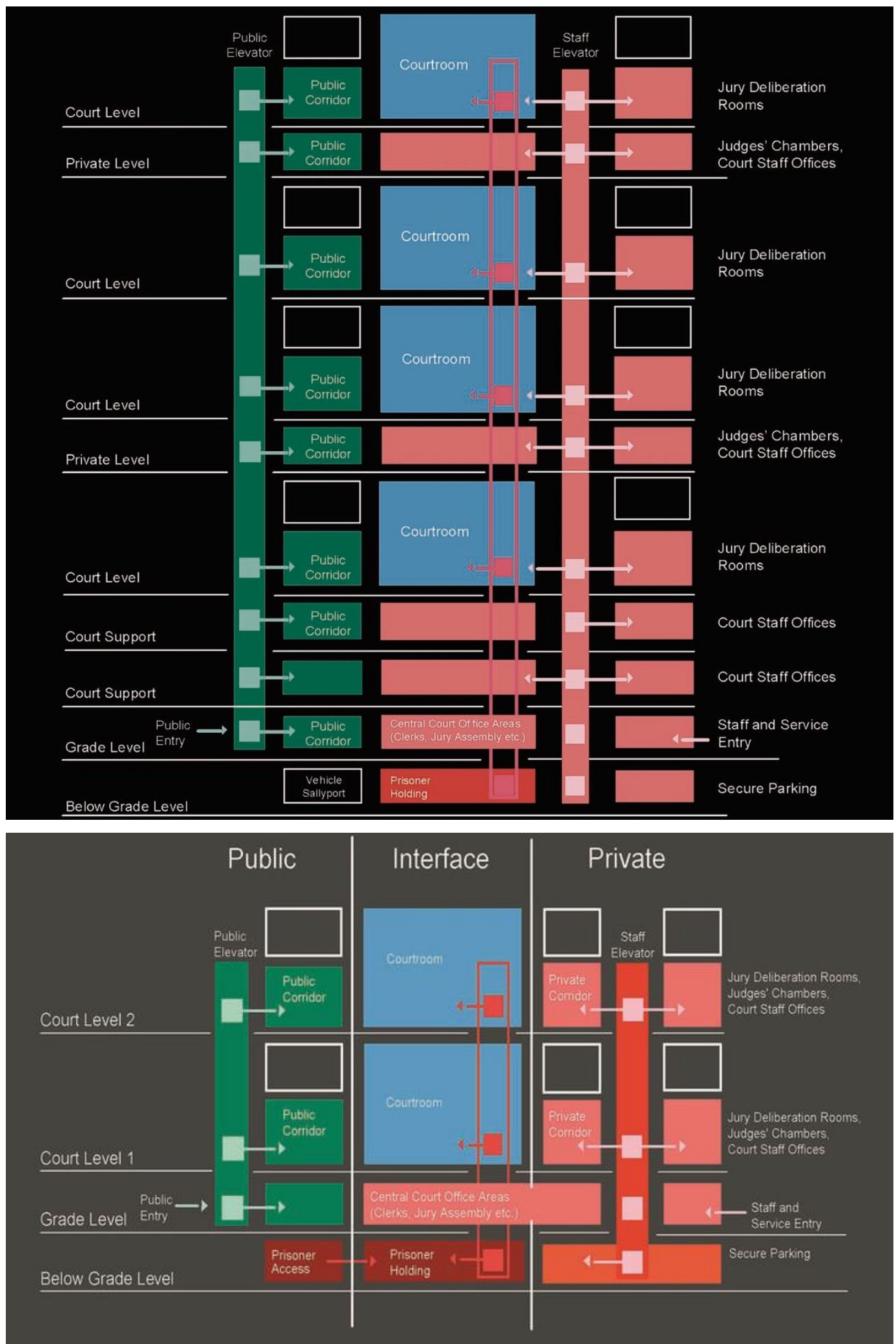

Figure 9. Stacking scheme in courthouse. (Source: The Virtual Courthouse, n.d., by HOK) 
Figure 10 shows the blocking scheme on the courtroom floor. Courtrooms are clustered in groups of two, four, six, or eight, with shared support spaces. Court-related functions are placed near courtrooms. These include witness rooms, A/V room, evidence room, and detention area. Jury deliberation rooms are located near trial courtrooms and accessed from private circulation. Judges' suites are located on the courtroom floor behind the courts or on dedicated floor(s). In a courthouse with 10 or less courtrooms, each judge is assigned a courtroom. In larger courthouses, courtrooms can be shared.

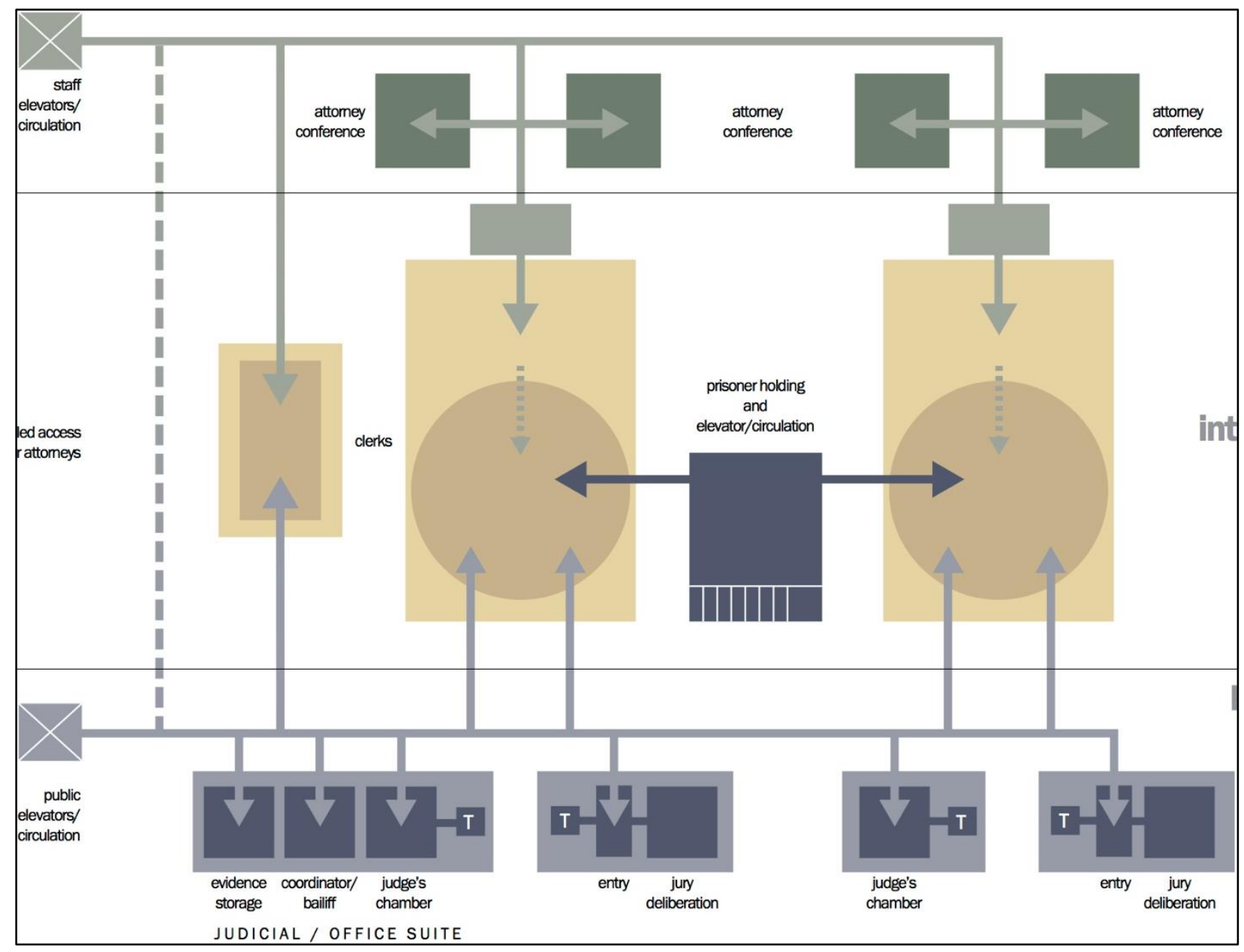

Figure 10. Blocking scheme in courtroom floor (public, private and interface zones). (Source: The Virtual Courthouse, n.d., by HOK) 


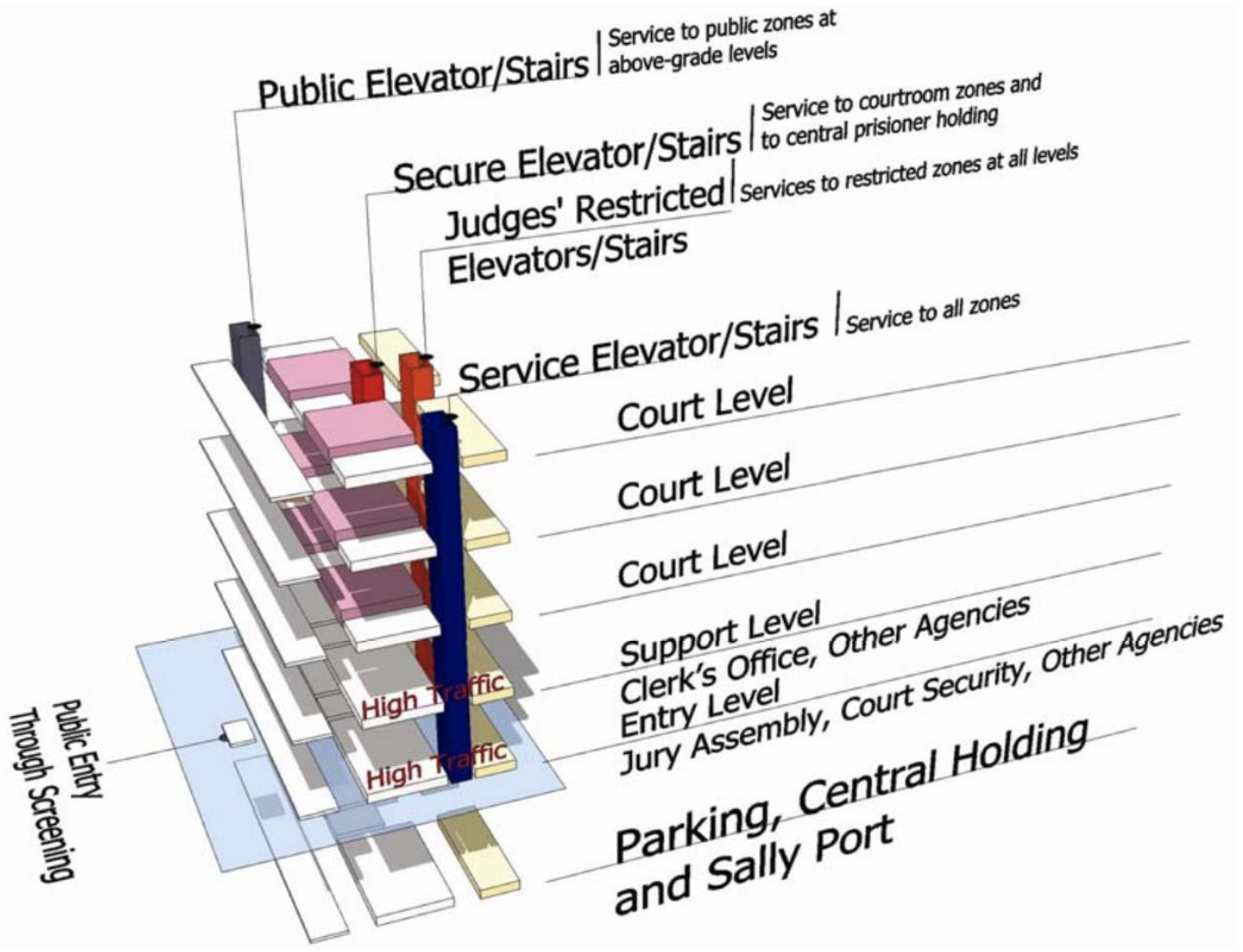

(a)

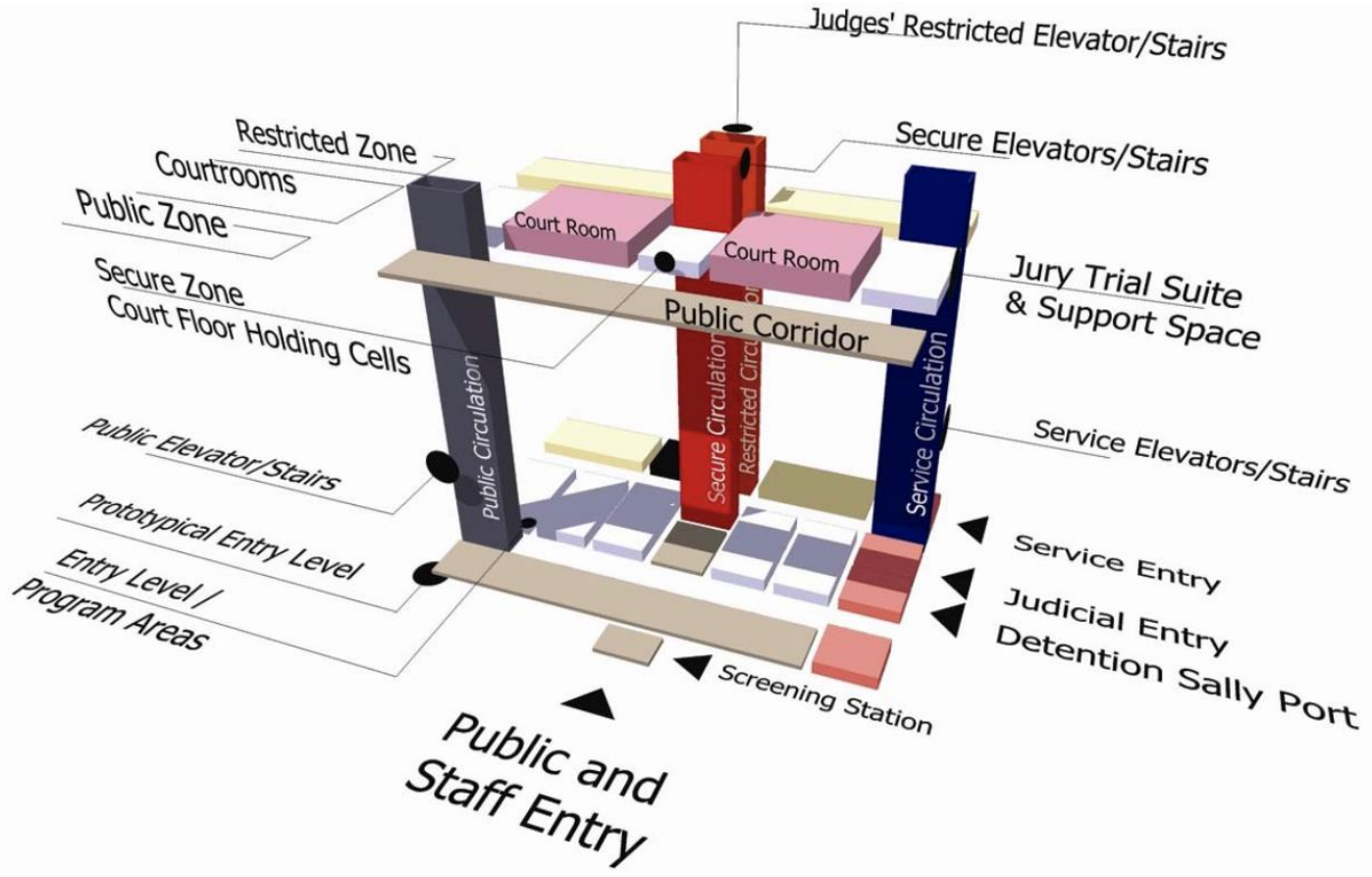

(b)

Figure 11. Typical space organization in a federal courthouse. (Source: USCDG 2007) 


\subsection{BUILDING SIZE AND SPACE REQUIREMENT DETERMINANTS}

According to Hardenbergh (2015), the number of courtrooms is the main determinant of the scale of a courthouse, and a primary indicator of size for courthouses. Additionally, the courtrooms are the major factor determining the number and size of the judicial, clerk, public, technical and other spaces throughout the building.

California Trial Court Facilities Standards (2011) recommends building GSF of 9,000-14,000 per courtroom. Hardenbergh (2015) reports a range of 12,000 to 17,000 BGSF per courtroom base on a national court project and recommends between 13,000 and 16,000 BGSF per courtroom for courthouses in Virginia.

USCDG (2007) categorizes courthouse based on the number of courtrooms, small for up to 5 courtrooms, medium for 6-12 courtrooms and large for more than 12 courtrooms. Based on the number of floors, it designates courthouses as low-rise (up to 4 floors above grade), mid-rise (5-9 floors above grade) and high-rise (10 or more floors above grade).

Ratio of Courtrooms to Judges: According to The Virtual Courthouse (n.d.), one courtroom per judge is typical. In less populated areas, one courtroom may be shared by several divisions of the same court, or by different courts. Some courts have adopted a ratio of one courtroom per judge until the court reaches about ten judges; above that number, the court may need only three courtrooms for every four judges. For courtroom sharing to work, all courtrooms should be identical in their capabilities. All should be capable of holding a criminal jury trial. It is to be noted that not every hearing or proceeding has to take place in a courtroom; many can be held in chambers or in a smaller hearing or conference room.

Ratio of Jury Deliberation Rooms to Courtrooms: According to The Virtual Courthouse (n.d.), the precise ratio of jury deliberation rooms to courtrooms depends on many factors, some experts use a rule of one jury deliberation room per courtroom until the court expands to more than four or five courtrooms, at which point a ratio of $75 \%$ is typically applied. Criminal courts may require a higher ratio of deliberation rooms per courtroom than civil, municipal, and traffic courts. Some courts have used a ratio of six or seven deliberation rooms per ten jury courtrooms, as long as deliberation rooms are accessible to all courtrooms.

Ratio of Jury to Non-Jury Courtrooms: The ratio of jury to non-jury courtrooms, likewise, depends upon several factors. The most flexible situation is for each courtroom to have a jury box or space for a jury box. As a general rule, unless jury trials are extremely rare, the court should plan to make most courtrooms jury-capable.

\subsection{SPACES-SPECIFIC REQUIREMENTS}

\subsubsection{Area}

Courthouse design guides provide guidance on floor area requirements for different spaces. GSA Unit Cost Study (GSA n.d.) provides example area program ( 
Table 1) and floor plans (Figure 12, Figure 13, and Figure 14) of low-, mid-, and high-rise federal courthouses. A comparison among these shows the commonalities and size-related variations in space area requirements to assist determinations for space sizes in the prototype model. 
Table 1. Area program for low-rise, mid-rise and high-rise federal courthouse to assist in development and potential modification of a Courthouse prototype building energy model.

\begin{tabular}{|c|c|c|c|c|c|c|}
\hline & \multicolumn{6}{|c|}{ Low-rise Mid-rise High-rise } \\
\hline Number of floors below grade & 1 & 1 & 2 & & & \\
\hline Number of floors above grade & 3 & 5 & 20 & & & \\
\hline Penthouse & 1 & - & 1 & & & \\
\hline Number of courtrooms & 5 & 10 & 20 & & & \\
\hline Footprint & 38,584 & 43296 & 24,000 & & & \\
\hline Building GSF & 136,600 & 262000 & 436,700 & & & \\
\hline Court USF & 86,620 & 174,030 & 276,306 & & & \\
\hline Efficiency & $63.4 \%$ & $66.4 \%$ & $63.3 \%$ & & & \\
\hline \multirow{2}{*}{ Court Component } & Low-rise & Mid-rise & High-rise & Low-rise & lid-rise & h-rise \\
\hline & \multicolumn{3}{|c|}{ USF } & \multicolumn{3}{|c|}{ Percent USF } \\
\hline District Judge Courtroom \& Associated Spaces & 2,591 & 5,074 & 10,450 & $3.0 \%$ & $2.9 \%$ & $3.8 \%$ \\
\hline Courtroom & 2,630 & 5,260 & 10,520 & $3.0 \%$ & $3.0 \%$ & $3.8 \%$ \\
\hline Detention & 315 & 630 & 1,260 & $0.4 \%$ & $0.4 \%$ & $0.5 \%$ \\
\hline District Judge Chambers Suites & 2,518 & 4,916 & 9,651 & $2.9 \%$ & $2.8 \%$ & $3.5 \%$ \\
\hline Senior District Judge Courtroom \& Associated Spaces & 2,591 & 5,074 & 10,148 & $3.0 \%$ & $2.9 \%$ & $3.7 \%$ \\
\hline Courtroom & 2,630 & 5,260 & 10,520 & $3.0 \%$ & $3.0 \%$ & $3.8 \%$ \\
\hline Detention & 315 & 630 & 1,260 & $0.4 \%$ & $0.4 \%$ & $0.5 \%$ \\
\hline Senior District Judge Chambers Suites & 2,217 & 4,434 & 8,867 & $2.6 \%$ & $2.5 \%$ & $3.2 \%$ \\
\hline Magistrate Judge Courtroom \& Associated Spaces & 2,248 & 8,774 & 17,548 & $2.6 \%$ & $5.0 \%$ & $6.4 \%$ \\
\hline Courtroom & 2,130 & 8,520 & 17,040 & $2.5 \%$ & $4.9 \%$ & $6.2 \%$ \\
\hline Detention & 315 & 1,260 & 2,520 & $0.4 \%$ & $0.7 \%$ & $0.9 \%$ \\
\hline Magistrate Judge Chambers Suites & 1,699 & 6,795 & 13,590 & $2.0 \%$ & $3.9 \%$ & $4.9 \%$ \\
\hline Judicial Restricted Elevators \& Stairs & 1,800 & 1,800 & 6,300 & $2.1 \%$ & $1.0 \%$ & $2.3 \%$ \\
\hline Juror Assembly & 1,359 & 2,926 & 5,278 & $1.6 \%$ & $1.7 \%$ & $1.9 \%$ \\
\hline Grand Jury Suites & 710 & 710 & 710 & $0.8 \%$ & $0.4 \%$ & $0.3 \%$ \\
\hline Grand Jury Room & 650 & 650 & 650 & $0.8 \%$ & $0.4 \%$ & $0.2 \%$ \\
\hline Joint Use Spaces \& ADR & 661 & 833 & 2,184 & $0.8 \%$ & $0.5 \%$ & $0.8 \%$ \\
\hline District Clerk & 8,153 & 9,807 & 16,927 & $9.4 \%$ & $5.6 \%$ & $6.1 \%$ \\
\hline Probation & 7,457 & 9,105 & 12,344 & $8.6 \%$ & $5.2 \%$ & $4.5 \%$ \\
\hline Pretrial Services & 2,937 & 4,330 & 6,265 & $3.4 \%$ & $2.5 \%$ & $2.3 \%$ \\
\hline Federal Public Defender & 3,901 & 3,988 & 6,722 & $4.5 \%$ & $2.3 \%$ & $2.4 \%$ \\
\hline Bankruptcy Clerk & 8,739 & 11,286 & 16,434 & $10.1 \%$ & $6.5 \%$ & $5.9 \%$ \\
\hline Bankruptcy Judge Courtroom \& Associated Spaces & 1,557 & 3,475 & 6,536 & $1.8 \%$ & $2.0 \%$ & $2.4 \%$ \\
\hline Courtroom & 2,130 & 4,260 & 8,520 & $2.5 \%$ & $2.4 \%$ & $3.1 \%$ \\
\hline Bankruptcy Judge Chambers Suites & 1,699 & 3,398 & 6,795 & $2.0 \%$ & $2.0 \%$ & $2.5 \%$ \\
\hline Shared Chambers Collection Circuit Satellite Library & - & 6,263 & 8,329 & & $3.6 \%$ & $3.0 \%$ \\
\hline US Attorney & 6,436 & 14,573 & 27,009 & $7.4 \%$ & $8.4 \%$ & $9.8 \%$ \\
\hline US Marshal & 4,700 & 5,184 & 8,200 & $5.4 \%$ & $3.0 \%$ & $3.0 \%$ \\
\hline Main Cell Block Holding \& Detention Elevators & 3,405 & 4,800 & 6,760 & $3.9 \%$ & $2.8 \%$ & $2.4 \%$ \\
\hline US Trustee & 835 & 1,575 & 2,815 & $1.0 \%$ & $0.9 \%$ & $1.0 \%$ \\
\hline GSA & 3,663 & 3,663 & 5,142 & $4.2 \%$ & $2.1 \%$ & $1.9 \%$ \\
\hline Joint Use Retail Other Agencies & 3,628 & 24,777 & 9,012 & $4.2 \%$ & $14.2 \%$ & $3.3 \%$ \\
\hline SUBTOTAL USF for Court and Related Agencies & 86,620 & 174,030 & 276,306 & & & \\
\hline Restricted Covered Parking Area & 11,000 & 15,000 & 20,000 & $11.3 \%$ & $7.9 \%$ & $6.7 \%$ \\
\hline TOTAL USF & 97,620 & 189,030 & 296,306 & & & \\
\hline
\end{tabular}




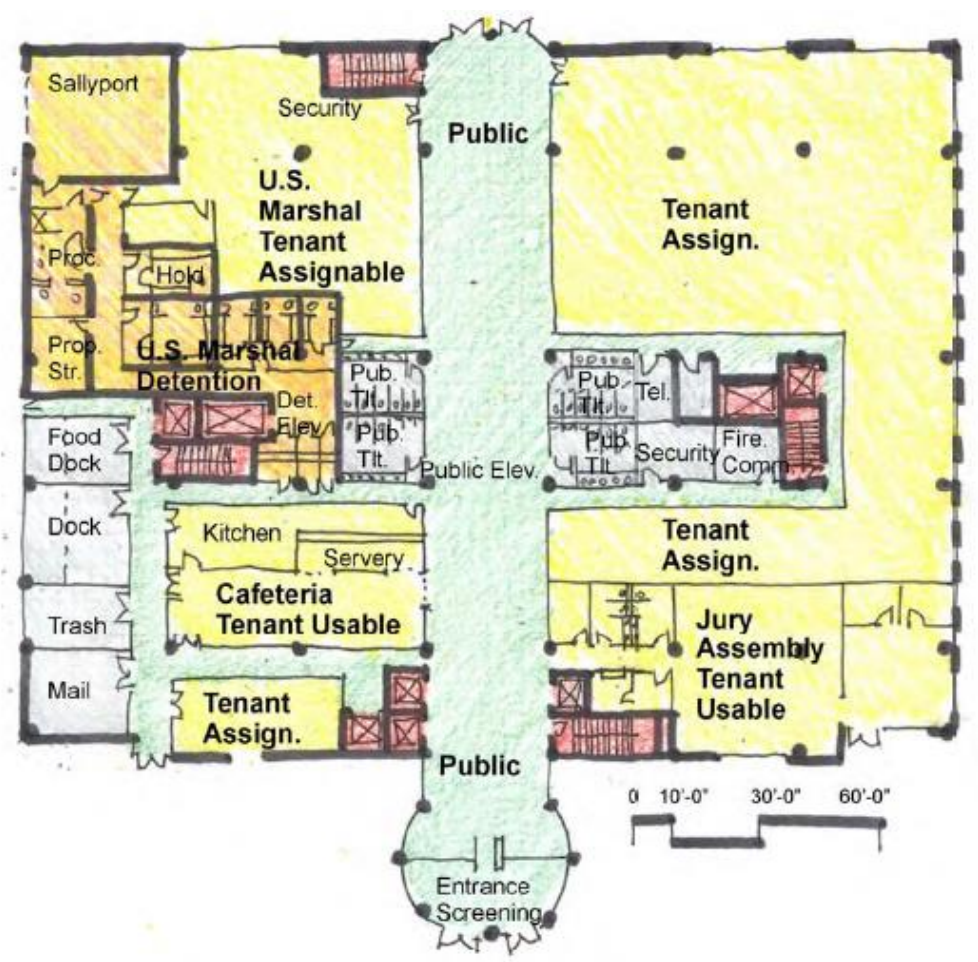

\section{Low Rise Courthouse - Ground Floor}

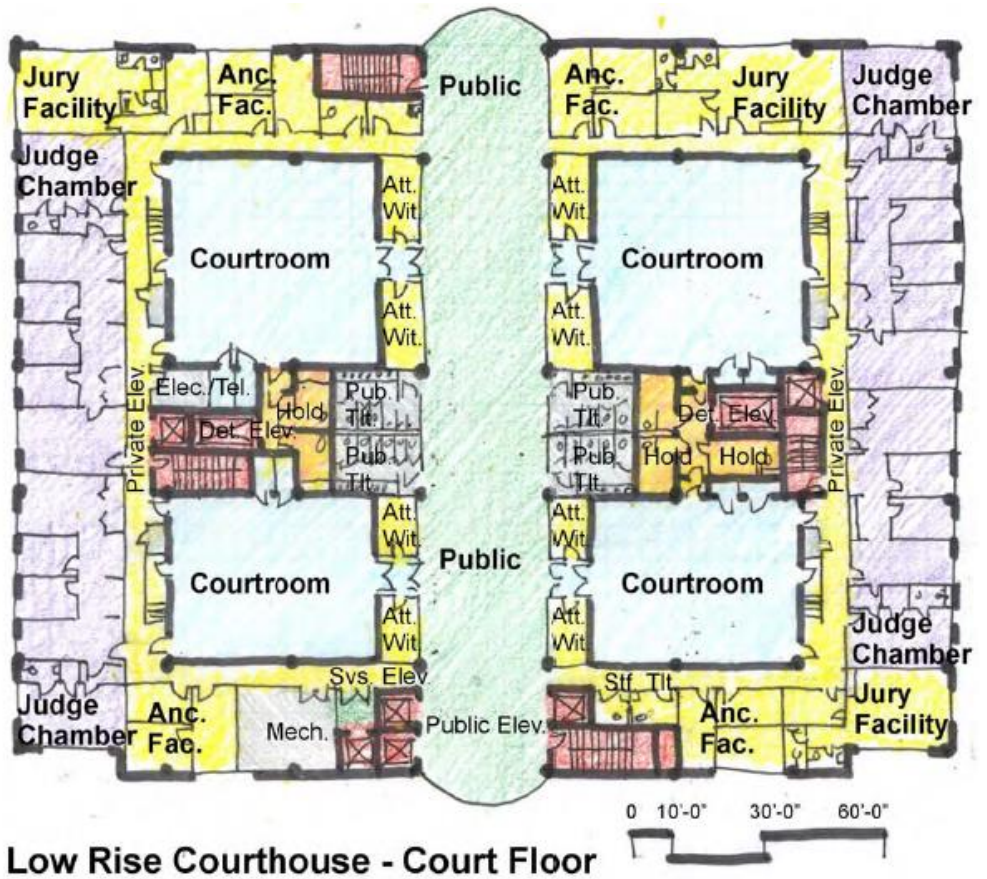

Figure 12. Example building plan for low-rise federal courthouse. Source: Shell \& Core: Courthouse (GSA, n.d.) 

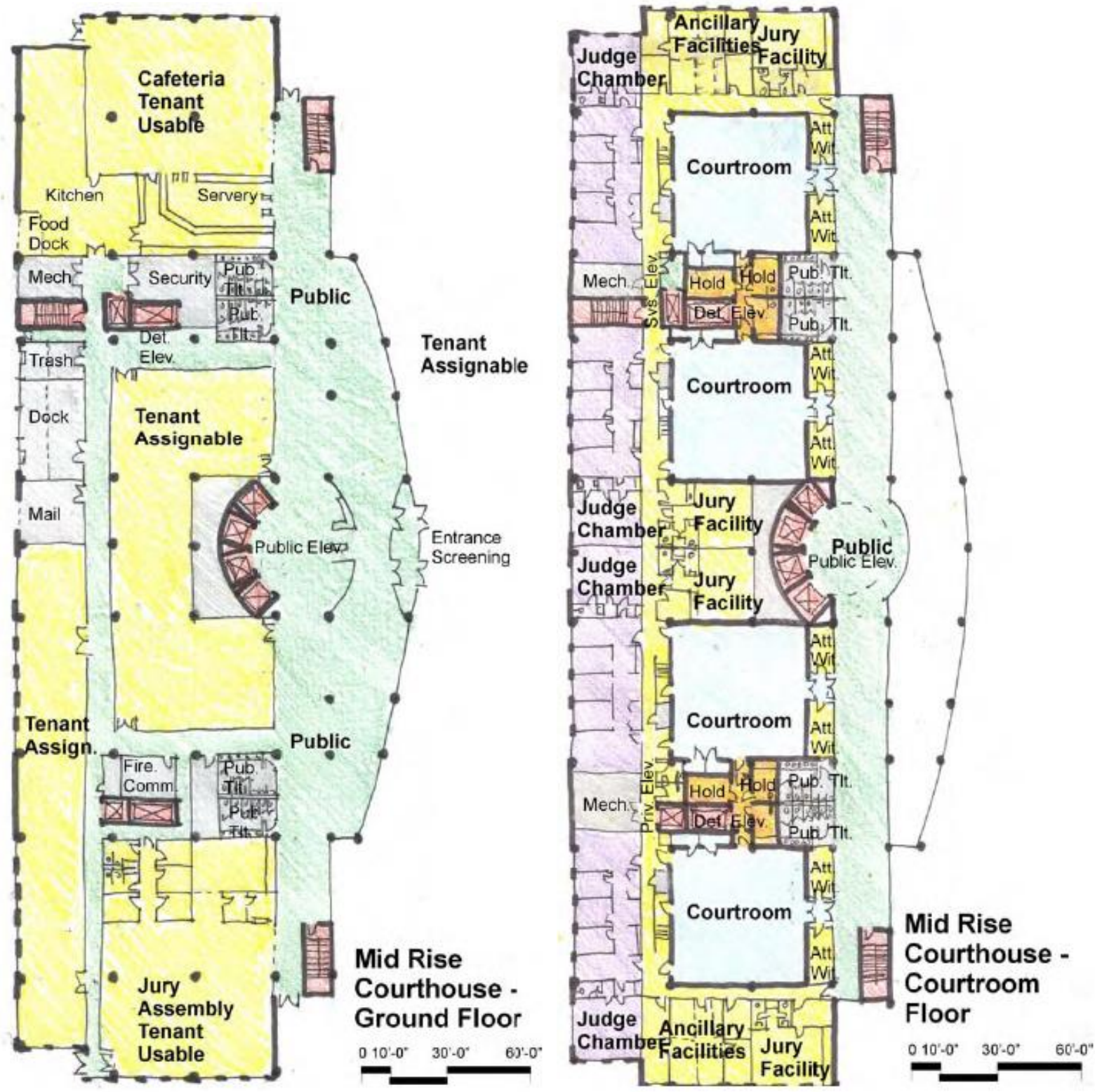

Figure 13. Example building plan for mid-rise federal courthouse.

Source: Shell \& Core: Courthouse (GSA, n.d.) 


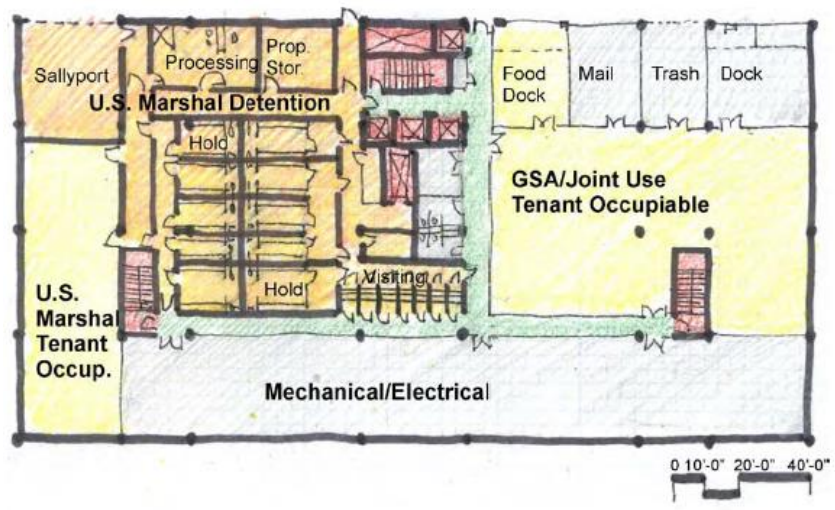

High Rise Courthouse - Basement

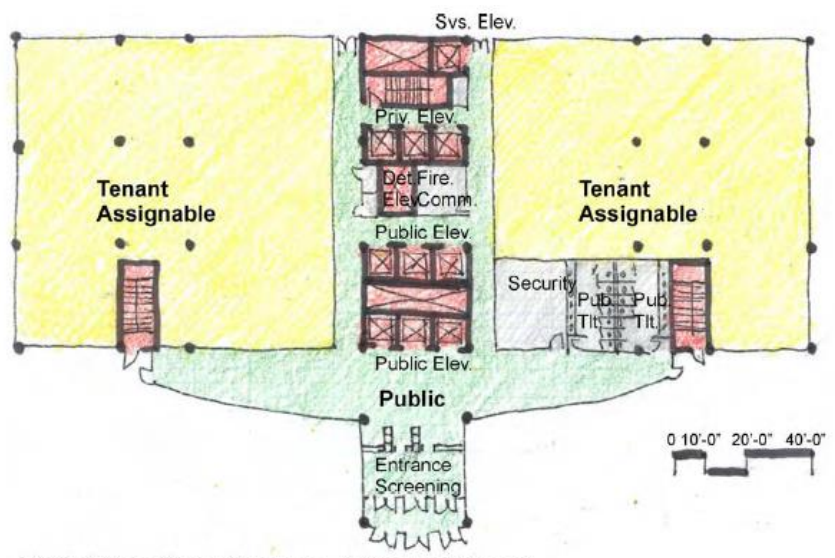

High Rise Courthouse - Ground Floor

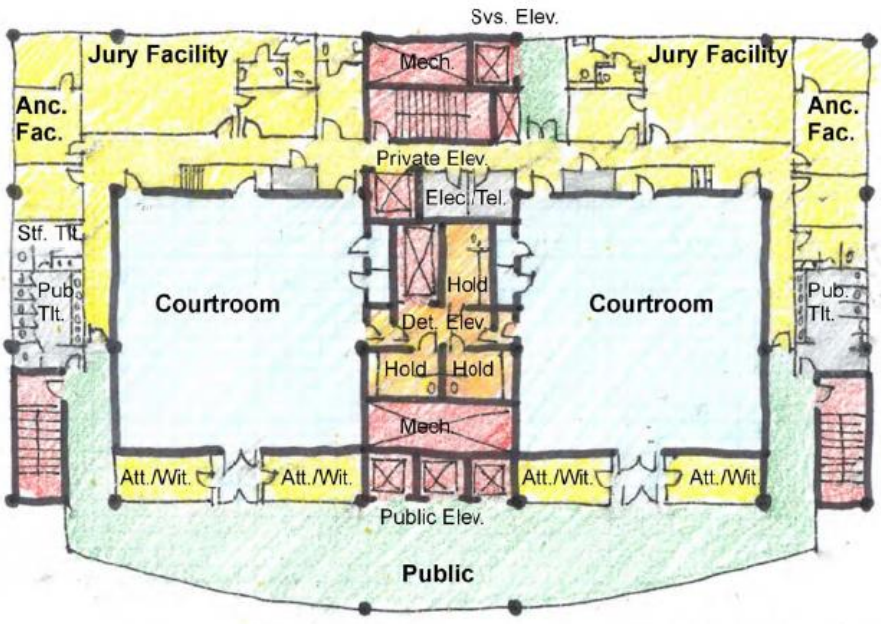

High Rise Courthouse - Court Floor

Figure 14. Example building plan for high-rise federal courthouse. Source: Shell \& Core: Courthouse (GSA, n.d.) 


\subsubsection{Ceiling Height}

The Virtual Courthouse (n.d.) recommends courtrooms be designed with 12-14 feet (14-18 feet for large courtrooms exceeding 1,700 sq ft) ceiling height at litigation area and 9-10 feet (10$12 \mathrm{ft}$ for large courtroom) at spectator area (Figure 15). For efficient planning, it recommends considering dedicating the entire floor(s) with higher floor-tofloor/ceiling height for courtrooms.

USCDG (2007) specifies maximum ceiling height of 16-18 feet for courtrooms, 12 feet for clerk's office and 10 feet for all other spaces for federal courthouses.

California Trial Court Facilities Standard (2011) provides space-specific typical ceiling heights, as shown in Figure 16.

GSA (2017a) specifies that for determining the floor-to-floor height, the height of the accessible floor system ${ }^{8}$ must be included. Floor-to-floor heights must provide adequate space under raised access floors (and above the ceiling assembly) to allow for all systems within the floor cavity (and ceiling cavity) to be placed without interference with each other and to have adequate access for maintenance.

\subsubsection{Occupancy and Internal Loads}

\section{Occupancy}

\begin{tabular}{lr} 
SPACE & HEIGHT \\
\hline Courtroom & $12-15^{\prime}$ \\
\hline Chambers & $8^{\prime}-10^{\prime}$ \\
\hline Public Lobby & Varies \\
\hline Open Plan & $9^{\prime}-10^{\prime}$ \\
\hline Private Offices & $9^{\prime}$ \\
\hline Clerk's Public Spaces & $9^{\prime}-10^{\prime}$ \\
\hline Jury Assembly Room & $10^{\prime}-12^{\prime}$ \\
\hline Jury Deliberation Room & $8^{\prime}-10^{\prime}$ \\
\hline Public Corridors & $9^{\prime}-12^{\prime}$ \\
\hline Restricted Corridors & $8^{\prime}-9^{\prime}$ \\
\hline Ancillary Spaces & $8^{\prime}-10^{\prime}$ \\
\hline
\end{tabular}

Figure 16. Typical ceiling heights.

Source: California Trial Court Facilities Standard (2011)

Courthouse buildings are used by a variety of people including judges, attorneys, witnesses, victims, in-custody defendants, clerks, other employees, outside social agencies, the press, and the public.

- Courtrooms: occupied all day ( 9 am to $5 \mathrm{pm}$ ), occupied by the judge, attorneys, jury members and alternates (if jury trial court), other staff, and 35 or more visitors; observes a lunch break.

$\circ \quad$ A/V room: only lighting and plug loads

\footnotetext{
${ }^{8}$ Accessible flooring systems can be defined as a suspended floor plane above the structural slab with relocatable modular components. Raised access floor systems for Federal facilities must use a minimum of $150 \mathrm{~mm}$ (6 in.) above the concrete deck to allow adequate space for wire management systems and the crossing of large conduits (GSA 2017a).
} 
○ Attorney-client/witness rooms: 2 per courtroom, up to 4 people

- Court room waiting: up to 20 people per courtroom (witnesses and visitors)

- Judges suite: One judge, up to 4 staff

- Clerk: open plan and private offices

- Jury assembly area: 20 people per courtroom

- Jury deliberation rooms: like conference rooms, 12-16 people, two toilets per room

- Prisoner holding: occupied only during the day; size and capacity vary by courtroom

- Secured corridor:

\section{Lighting systems}

- The use of indirect pendant-mounted fluorescent fixtures for general lighting in a courtroom, complemented with recessed concentrated light sources at the judge's bench, the witness box, and attorneys' tables.

- Remote electronic dimmers with preset lighting arrangements, for large courtrooms with high ceilings.

- Electronic ballasts for fluorescent lamps must not be used in areas that contain sensitive security devices or special equipment that is sensitive to electronic interference, such as assisted listening device (ALD) infrared emitters.

- New courthouses predominantly use LED lighting.

\section{Equipment and plug loads:}

- Computers in all offices/desks, clerks, courtrooms, holding areas

- $\mathrm{A} / \mathrm{V}$ equipment in courtrooms/support spaces, jury assembly area

- Plug loads and kitchenette in judge's chambers suite, jury assembly, and staff areas

- Elevators: public elevators, private elevators for judges, secure elevators for in-custody defendants, service elevators

- Sump pump, if basement is present

- Electric heating for outdoor walkways, garage ramp

- Courthouse-specific security devices

California Trial Court Facilities Standards (2011) specifies indoor design conditions for courthouse spaces, as shown in 
Table 2. 
Table 2. Indoor design conditions. Source: California Trial Court Facilities Standards (2011)

\begin{tabular}{|c|c|c|c|c|c|}
\hline \multirow{2}{*}{ ROOM TYPE } & \multirow{2}{*}{$\begin{array}{c}\begin{array}{c}\text { Occupant } \\
\text { density }\end{array} \\
\mathrm{ft}^{2} / \text { person } \\
\end{array}$} & \multirow{2}{*}{$\begin{array}{c}\begin{array}{c}\text { Lighting } \\
\text { density }\end{array} \\
\text { W/ft }{ }^{2} \\
\end{array}$} & \multirow{2}{*}{$\begin{array}{r}\begin{array}{r}\text { Power } \\
\text { density }\end{array} \\
W / \mathbf{f t}^{3}\end{array}$} & \multicolumn{2}{|c|}{ AIRFLOW } \\
\hline & & & & cfm/person & $\mathbf{c f m} / \mathbf{f t}^{2}$ \\
\hline Lobby & 33 & 1.9 & 0.5 & 5 & 0.06 \\
\hline Offices & 150 & 1.1 & 2.5 & 5 & 0.06 \\
\hline Jury Services & 32 & 1.4 & 1 & 5 & 0.06 \\
\hline Hearing Rooms & 26 & 1.1 & 0.5 & 5 & 0.06 \\
\hline Judicial Chambers & 150 & 1.1 & 0.5 & 5 & 0.06 \\
\hline Break Rooms & 20 & 1.1 & 1.1 & 5 & 0.06 \\
\hline IDF Rooms (server room) & 150 & 1.1 & & 5 & 0.06 \\
\hline Waiting Rooms & 33 & 1.4 & 0.5 & 5 & 0.06 \\
\hline Public Gallery/Passage & 50 & 1.1 & 0.5 & 5 & 0.06 \\
\hline Parking Garage & & & & & .75 exhaust \\
\hline Public Toilet Rooms & 200 & 1.1 & 1.1 & & $70 \mathrm{cfm} /$ fixture \\
\hline Mechanical Rooms & 200 & 1.1 & 1.1 & 5 & 0.06 \\
\hline Holding Cell with Toilet & 40 & 0.9 & & 5 & 0.06 \\
\hline \multicolumn{6}{|l|}{ Transformer/Switchgear Room } \\
\hline Telephone Equipment Room & 200 & & 50 & 5 & 0.06 \\
\hline Janitor Closets & 200 & & & 5 & 0.06 \\
\hline Basement Holding & 40 & 1.1 & & 5 & 0.12 \\
\hline Copy Rooms & 200 & 1.1 & 20 & & 1 exhaust \\
\hline Day Care & 40 & 1.1 & 1.5 & 5 & 0.18 \\
\hline Storage & 200 & 0.5 & 0.5 & 5 & 0.12 \\
\hline Standard Criminal Courtrooms & 18 & 1.6 & 0.5 & 5 & 0.06 \\
\hline Probate Courtrooms & 21 & 1.6 & 0.5 & 5 & 0.06 \\
\hline Family Courtrooms & 21 & 1.6 & 0.5 & 5 & 0.06 \\
\hline Double-Jury Criminal Courtrooms & 14 & 1.6 & 0.5 & 5 & 0.06 \\
\hline
\end{tabular}

\subsubsection{HVAC Design Conditions}

US Court facilities require a variety of space types, each with its own set of specific requirements. In addition, court functions require flexibility in the time of operation and control of dedicated HVAC systems. USCGD (2007) provides guidelines and procedures for the selection of the HVAC systems, equipment, and source of energy as below:

$\circ$ Indoor air in courtrooms: $75^{\circ}+/-2^{\circ} \mathrm{F}$ in summer and $72^{\circ}+/-2^{\circ} \mathrm{F}$ in winter.

- Maintain 45-50\% relative humidity for summer conditions and $25-35 \%$ relative humidity for winter conditions. The design must include winter humidification for areas in the building with custom millwork.

- HVAC systems must be designed to provide optimum flexibility in scheduling the use of courtrooms and chamber areas 
- The HVAC system must be designed to provide $74^{\circ} \mathrm{F}$ in judges' chambers, courtrooms, and trial jury suites on average. The courtroom HVAC system must be designed so that courtroom thermostats can be reset from the building automation system to precool the courtrooms to $70^{\circ} \mathrm{F}$ before scheduled occupancy.

- Trial jury suites (when located adjacent to a courtroom), judges' chamber suites (when located adjacent to a courtroom), attorney/witness rooms, attorney work room, and courtrooms must be placed on the same system with separate zones having related thermostats and the design must account for variation in occupancy load.

- Mechanical systems will provide a minimum of $20 \mathrm{cfm}$ per person in all occupied areas.

- To allow flexible and efficient use of the HVAC systems for hours of activity occurring at times other than standard building operations and to satisfy specific requirements in a US Court facility, the central plant equipment (e.g. chillers, boilers, cooling towers, pumps, air handling units) must be designed using redundant equipment of various sizes to satisfy the requirements of a differing number and sizes of zones with the goal of servicing no more than two courtrooms per air handling unit.

- The HVAC system design for the courtroom, judge's chamber suite, and the jury deliberation room, which compose a single "court set," must be designed to allow the HVAC system to operate after standard building operations hours in an efficient manner.

- Piping systems must allow arrangements to permit changing courtroom HVAC systems from primary to secondary chilled water for off hours.

- Mechanical systems must be designed to minimize noise in the courtroom.

\section{Courtroom and chambers:}

- Air Distribution: Three HVAC zones must be provided: one for the judge and attorney areas, a second for the jury areas, and a third for the spectator area.

○ The maximum percentage of recirculated air must not exceed $85 \%$.

- If the courtroom is served by a fan system dedicated to more than one courtroom, the return air from each courtroom and its associated areas must be ducted directly to the unit.

\section{Jury Facilities:}

- System Description and Control: Trial jury suites should be served from the same system as the associated courtrooms. A separate thermostat for each trial jury room is desirable.

- Air distribution systems in the jury facilities must provide separate temperature control and a high degree of acoustical isolation, particularly in the grand jury and trial jury rooms.

- Air Changes: In the jury assembly suites, trial jury suites, grand jury suites, and libraries, the system must provide 10 air changes per hour $(\mathrm{ACH})$ with $80-85 \%$ return. 


\section{Information Technology System Loads}

- Information technology systems are not the largest source of heat within the office spaces, but may be the largest sources in other areas. Information technology systems may be the most uncertain source of heat flows during design phases; therefore, the HVAC system must be planned with capacity and control to accommodate the need for constant temperature and humidity environments 24 hours a day, where systems hardware could be placed.

- The design of the HVAC systems must take into consideration provisions for separate units for critical areas such as computer rooms, control room, and elevator machine rooms which generate additional heat loads. The HVAC design for these areas must have redundancy and be connected to the emergency power system. Computer and audio-visual equipment should be collocated where possible to reduce the number of separate areas requiring 24-hour cooling.

Two additional sources for courthouse building controls are California Trial Court Facilities Standards (2011), and 2015 ASHRAE Handbook HVAC Applications (2015). The California Trial Court Facilities Standards defines the thermostat setpoint for heating and cooling should be $72^{\circ} \mathrm{F} \pm 2^{\circ} \mathrm{F}$, and $75^{\circ} \mathrm{F} \pm 2^{\circ} \mathrm{F}$, respectively. The relative humidity of the building should be maintained with $50 \% \pm 5 \%$. ASHRAE Handbook Chapter 9 provides some requirements of the HVAC systems in Courthouses. The handbook defines that the indoor air should be maintained $74^{\circ} \mathrm{F}$ and $50 \% \mathrm{RH}$ for summer conditions and occupancy, and $72^{\circ} \mathrm{F}$ and $20-35 \% \mathrm{RH}$ for winter. ${ }^{9}$

The California Trial Court Facilities Standards provide more requirements for temperature control zone as below.

- Interior control zone shall not exceed 1,500 gross sq. ft. for open areas, or a maximum of three enclosed offices.

- Perimeter zones shall not exceed 400 gross sq ft, or a maximum of two enclosed offices

- Corner offices shall be independent zones.

- Provide independent zones for each courtroom, chambers suite, jury deliberation room, entrance lobby, mailroom, staff lounge, conference room, atrium, child waiting area, and equipment rooms.

ASHRAE Handbook - HVAC Applications (ASHRAE 2015) provides HVAC requirements by space types in Courthouse. Table 3 provides the space type and corresponding requirements.

\footnotetext{
${ }^{9}$ Architectural features in courtrooms are generally above standard conventional design, and often include wood and ornate ceilings, which require both temperature and humidity control (ASHRAE 2013).
} 
Table 3. HVAC requirements by space type

\begin{tabular}{|c|c|}
\hline Space Type & Requirements \\
\hline Courtrooms/Chambers & $\begin{array}{l}\text { - Temperature: } 74^{\circ} \mathrm{F} \text { for occupancy. } 70^{\circ} \mathrm{F} \text { precool before scheduled occupancy } \\
\text { - } \mathrm{RH}: 20 \% \text { for winter, and } 50 \% \text { for summer } \\
\text { - Ventilation: Provide } 6 \mathrm{ACH} \text { (up to } 15 \mathrm{ft} \text { ceiling height), or } 8 \mathrm{ACH} \text { (higher } \\
\text { ceiling height) }\end{array}$ \\
\hline Jury facility & $\begin{array}{l}\text { - Same system with the courtrooms } \\
\text { - Ventilation: } 10 \mathrm{ACH} \text { with } 80-85 \% \text { return and exhaust (in case of jury } \\
\text { assembly room, deliberation room, and associated toilet) }\end{array}$ \\
\hline $\begin{array}{l}\text { Jail Cells and US Marshal } \\
\text { Spaces }\end{array}$ & $\begin{array}{l}\text { - A separate air handling system which can be operated independently after } \\
\text { hours. } \\
\text { - A separate } 100 \% \text { fresh and exhaust air system for jail cells } \\
\text { - US Marshal spaces should be treated as normal office areas. }\end{array}$ \\
\hline
\end{tabular}




\section{BUILDING DATA}

This chapter presents findings from building databases and documented courthouse projects.

\subsection{BUILDING AREA}

Building area is reviewed from GSA Portfolio Data for federal courthouses (GSA 2017b), 2012 CBECS data for courthouses (EIA 2015), and courthouse projects included in the Retrospective book series (Hardenbergh 1992, Hardenbergh and Phillips 2001, and Yeh et al. 2010a).

\section{GSA Portfolio Data}

The GSA Portfolio Data (GSA 2017b) lists 158 federal courthouses. Federal courthouses are usually occupied by the US post office and other federal offices. Excluding non-court functions, covered parking, common spaces (lobbies, corridors, mechanical and electrical service areas, toilet, janitorial, loading docks), and vertical penetrations, courthouses comprise 17.23 million sq ft of court USF. Figure 17 shows court USF, non-court USF, common areas, and parking (which add up to the building GSF).

- $\quad$ BGSF ranged between 13,509 and 1,465,484 sq ft with an average of 219,284 sq ft. Court USF was $19-75 \%$ of BGSF with an average of $49 \%$. Parking occupied $0-32 \%$ of BGSF, with an average of $4.5 \%$. Common areas comprised $10-46 \%$ of BGSF with an average of $26 \%$.

- Court USF ranged between 4,236 sq ft and 787,841 sq ft, with an average of 109,044 sq ft and median of $54,778 \mathrm{sq} \mathrm{ft}$.
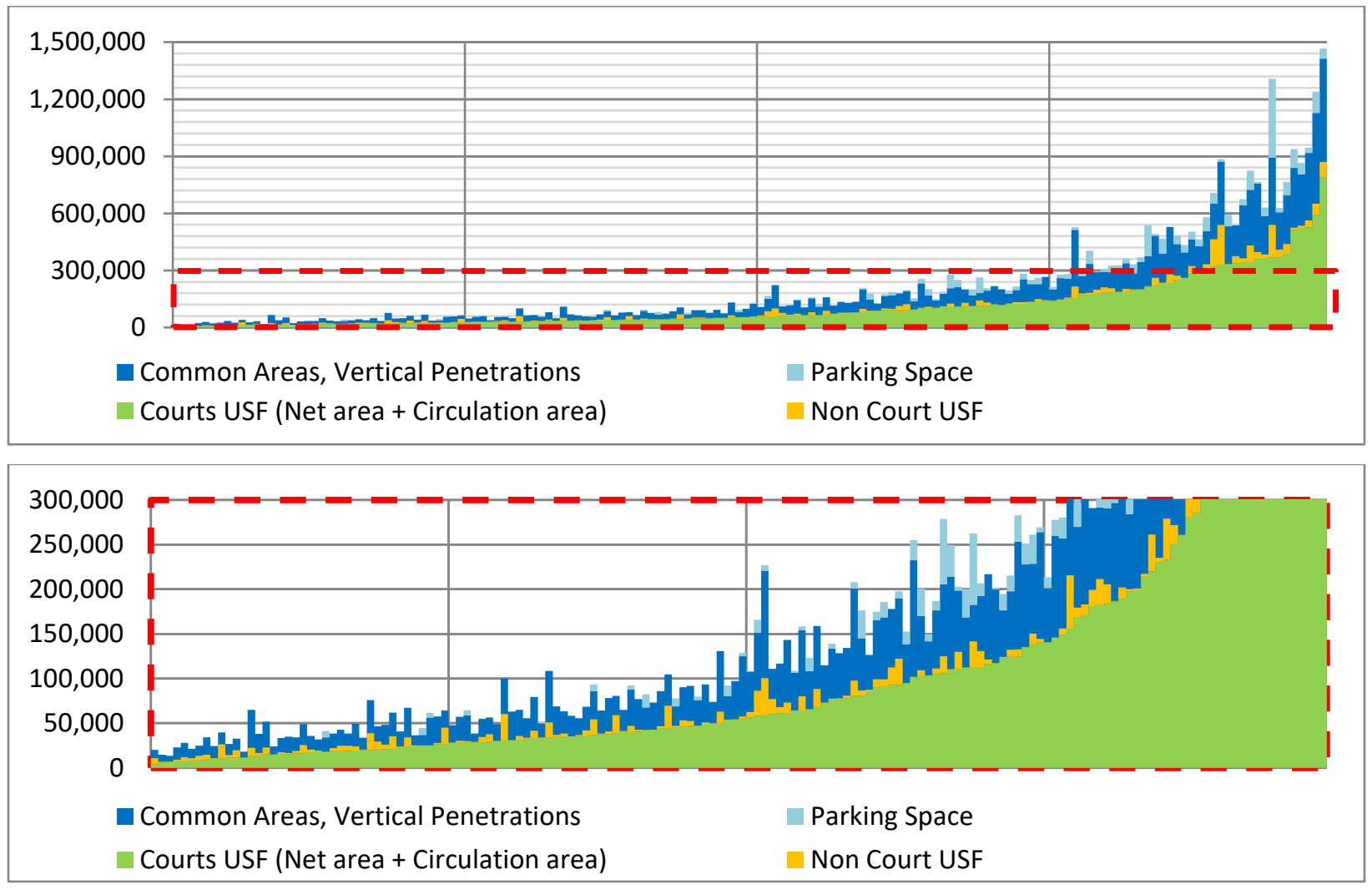

Figure 17. Area in Federal Courthouses. (Source: GSA 2017b) 
Figure 18 shows the percent buildings and percent floor space occupied by courthouses of different sizes. Cumulative percent is also plotted along the secondary y-axis. Since federal courthouse buildings are also occupied by the US post office and other federal offices, court USF is plotted in this figure. The following observations can be made in Figure 18:

- Court USF of 10,000-50,000 sq ft represents $43 \%$ of all courthouses, but they comprise only $11 \%$ of the total court USF.

- Most court USF is in the bins of 18,000-19,000 sq ft, 330,000-370,000 sq ft and 520,000-530,000 sq $\mathrm{ft}$, but together they represent only $9.5 \%$ of the buildings.

- Building with court USF less than or equal to average court USF (109,044 sq ft) represents $68 \%$ of buildings but comprise only $25 \%$ of total court USF.

- Building with court USF less than or equal to median court USF (i.e., 55,778 sq ft, representing $50 \%$ of buildings) comprise only $13 \%$ of total court USF.

- Five buildings with largest court USF comprise $17 \%$ of the total court USF.

- Buildings with a court USF of $135,000 \mathrm{sq} \mathrm{ft}$ or less comprise $75 \%$ buildings by number of buildings but only $33 \%$ of total floor space.

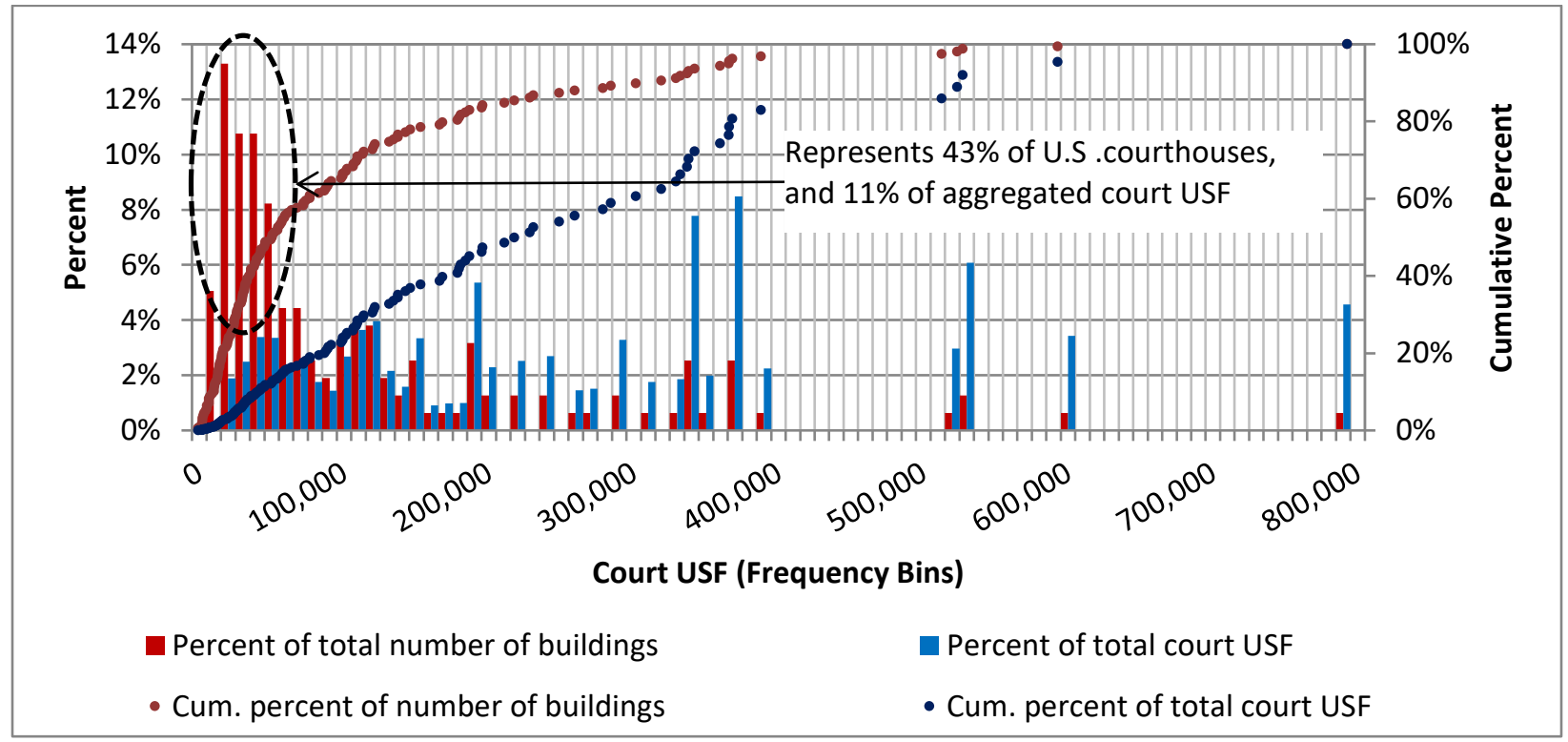

Figure 18. Percentage frequency and cumulative percentage frequency of federal courthouses by court USF (equal court USF bins). (Source: GSA 2017b)

Figure 19 shows percent frequency of court USF bins in federal courthouse. The bin size of court USF is varied (i.e., increasing bin size) to match and compare with those available in 2012 CBECS microdata (Figure 20). In federal courthouses, the court USF distribution is relatively uniform between $10,000 \mathrm{sq} f t$ and 500,000 sq ft. However, courthouses with 100,000-500,000 sq ft court USF comprise $60 \%$ of the total court USF. 


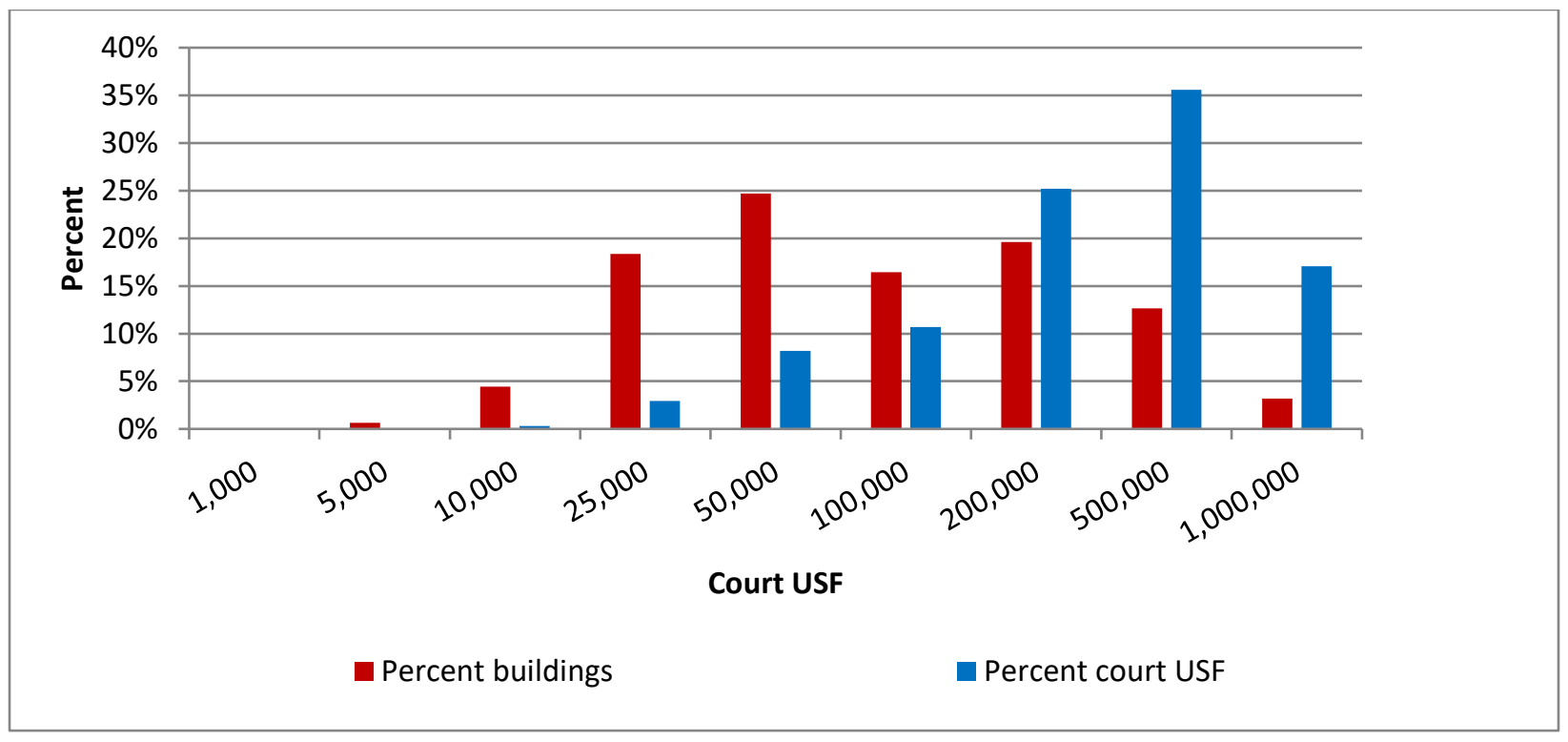

Figure 19. Percentage frequency of federal courthouse court USF (increasing bin size). (Source: GSA 2017b)

\section{CBECS Data}

The 2012 CBECS microdata (EIA 2015) indicates an average floor area of $69,400 \mathrm{sq} f \mathrm{ft}$ for courthouse. It is to be noted that the CBECS includes buildings greater than 1,000 square feet that devote more than half of their floor space to activity that is neither residential, manufacturing, industrial, nor agricultural. ${ }^{10}$ Further, the building type/subtype row category in the CBECS data tables presents a classification of the commercial activity that occupies the most floor space in the building.

Several courthouses are part of the buildings where other functions are performed. Several federal courthouses are part of the building, where other tenants include the US Postal Service, the US Marshals Service, Correctional Facilities, and Juvenile Facilities. Similarly, state courts may be in a municipality building or another state/county office building. A few state courts occupying part of mixed-use buildings may occupy less than $1,000 \mathrm{sq} \mathrm{ft}$.

Figure 20 and Figure 21 show percent frequency of courthouse square footage by bin categories and for sample building areas from 2012 CBECS data. In the 2012 CBECS, the area of sample courthouses range from 1,300-800,000 sq ft. The sample building weight is highest for 1,300 sq ft building (29.5\%), followed by $11,000 \mathrm{sq} \mathrm{ft}(18 \%)$. Approximately $50 \%$ of courthouses are very small buildings and yet they comprise a very small portion of the total building area of courthouse type. A majority of courthouse floor area is in buildings with areas above $250,000 \mathrm{sq} \mathrm{ft}$.

\footnotetext{
${ }^{10}$ Source: 2012 CBECS Preliminary Results. https://www.eia.gov/consumption/commercial/reports/2012/preliminary/
} 


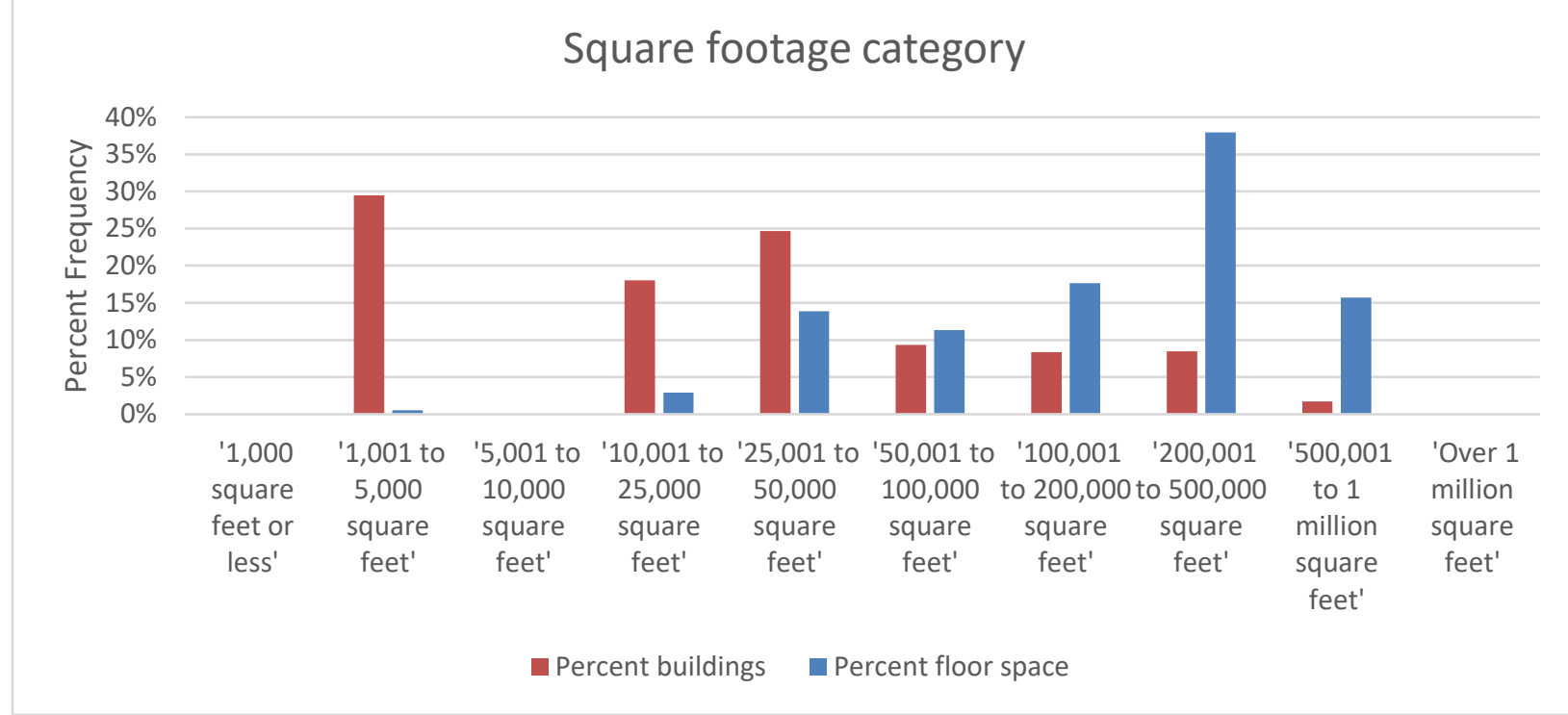

Figure 20. Percentage frequency of courthouse square footage categories (increasing bin size). (Source: EIA 2015)

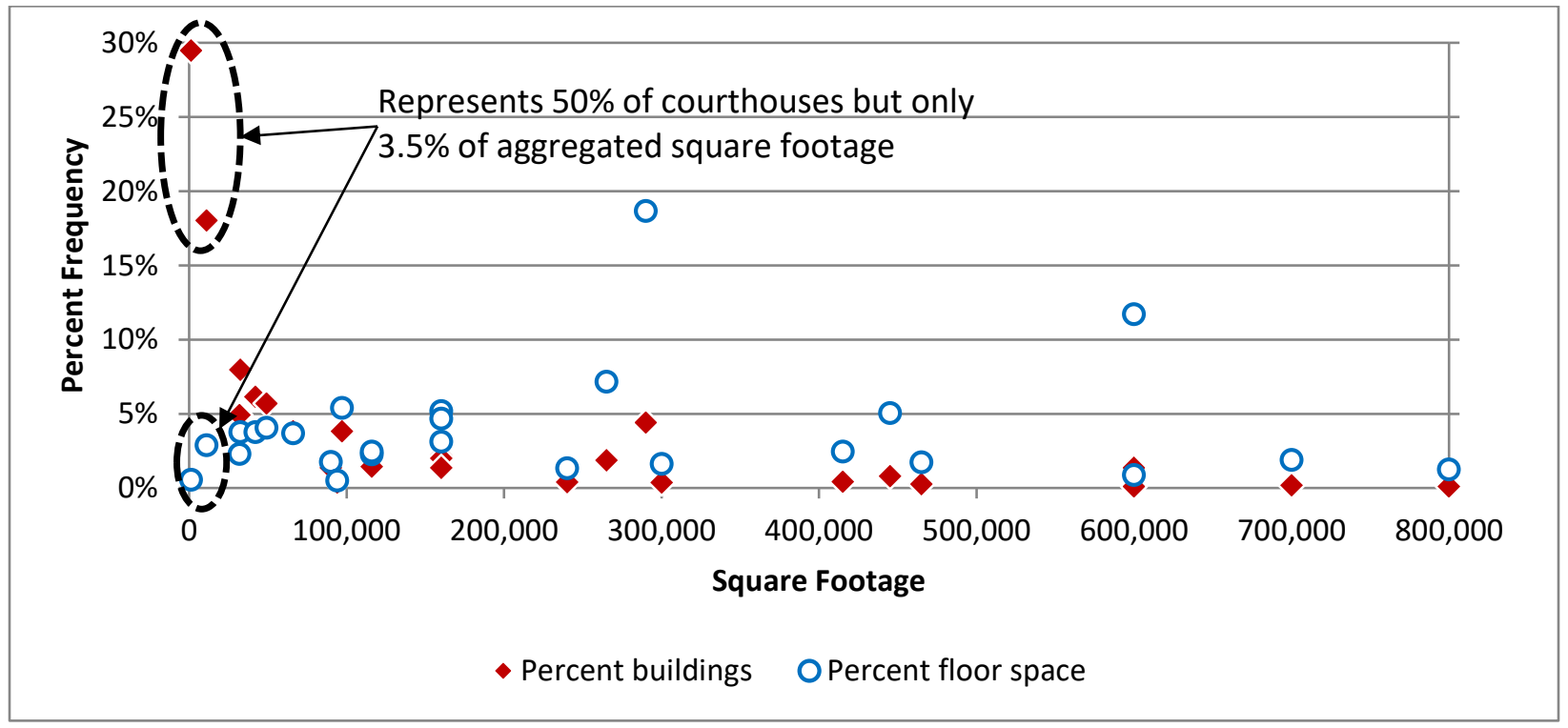

Figure 21. Percentage frequency of 2012 CBECS sample courthouse square footage. (Source: EIA 2015)

Figure 22 compares building floor area of commercial building prototype models and average floor area in 2006 and 2012 CBECS. It is worth noting that while the commercial building prototype energy models (black bars) represent an average CBECS building (blue and red bars) for many building types (e.g. fast food, restaurant, cafeteria, hospital, and warehouse), they have significantly large floor area for many other building types (middle school, high school, outpatient, large hotel, small hotel, and retail). 


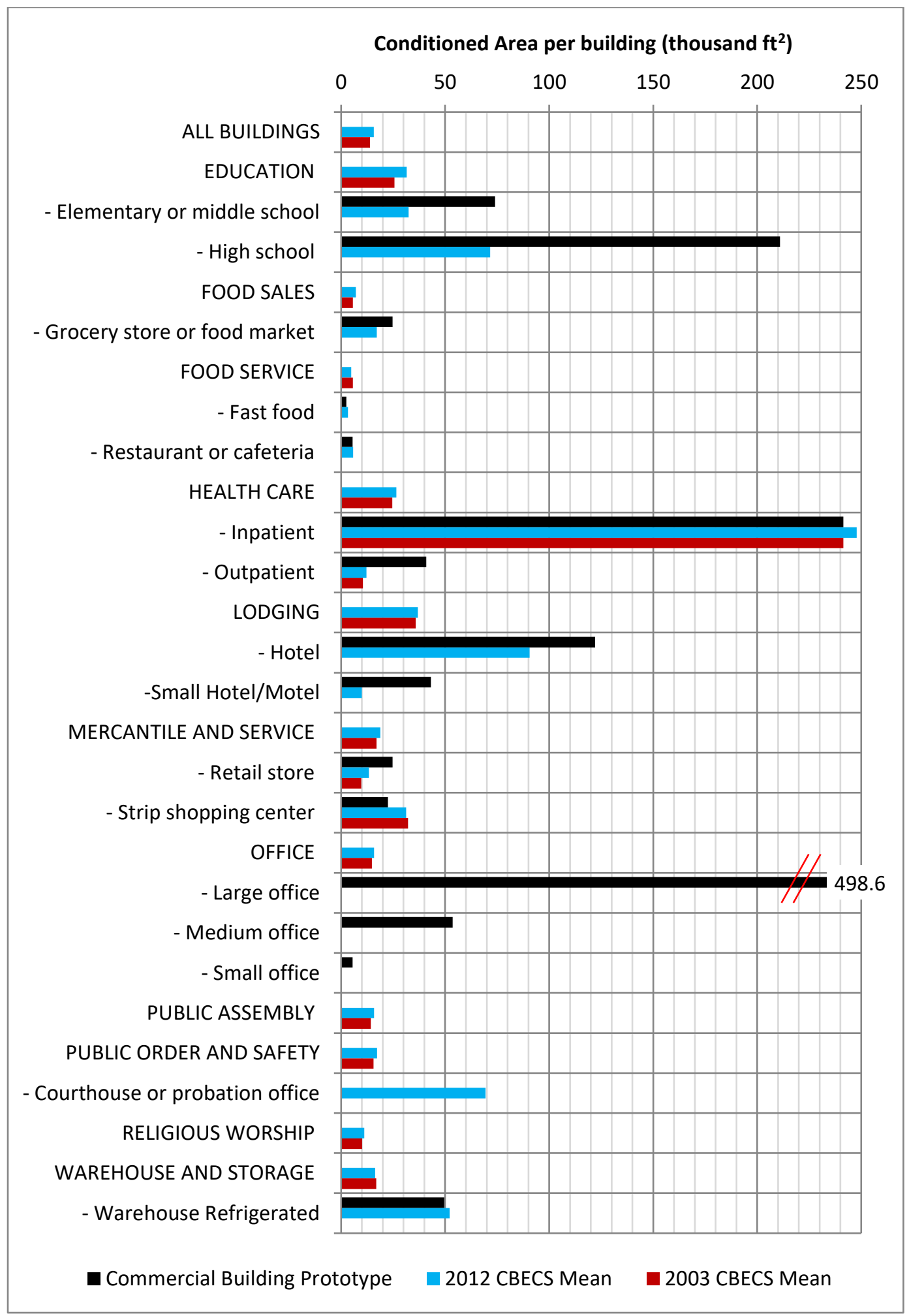

Figure 22. Building floor area for commercial building prototype models compared to 2003 and 2012 CBECS averages.

(Source: Building Energy Codes Program 2016. EIA 2008, EIA 2015) 


\section{Retrospective book series}

Courthouse projects included in the Retrospective book series (Hardenbergh 1992, Hardenbergh and Phillips 2001, and Yeh et al. 2010a) range from 3,000-1.3 million sq ft building floor area, and up to 74 courtrooms in a courthouse. Figure 23 and Figure 24 show the percent frequency of federal and state courthouses included in these publications by building gross square feet bins and by number of courtrooms, respectively. Figure 23 shows that over $38 \%$ of the document federal courthouses were from $200,000-500,000 \mathrm{sq} \mathrm{ft}$ bin and 15-20\% of courthouse were from each of the 50,000-100,000 sq ft, $100,000-200,000 \mathrm{sq} \mathrm{ft}$ and 500,000-1 million sq ft bins. Among the state courthouse, $30 \%$ were from the $100,000-200,000 \mathrm{sq} \mathrm{ft}$ bin and 30\% from the 500,000-1 million sq ft bins. On the other hand, Figure 24 shows that the documented courthouses represented courthouses of all sizes by number of courtrooms.

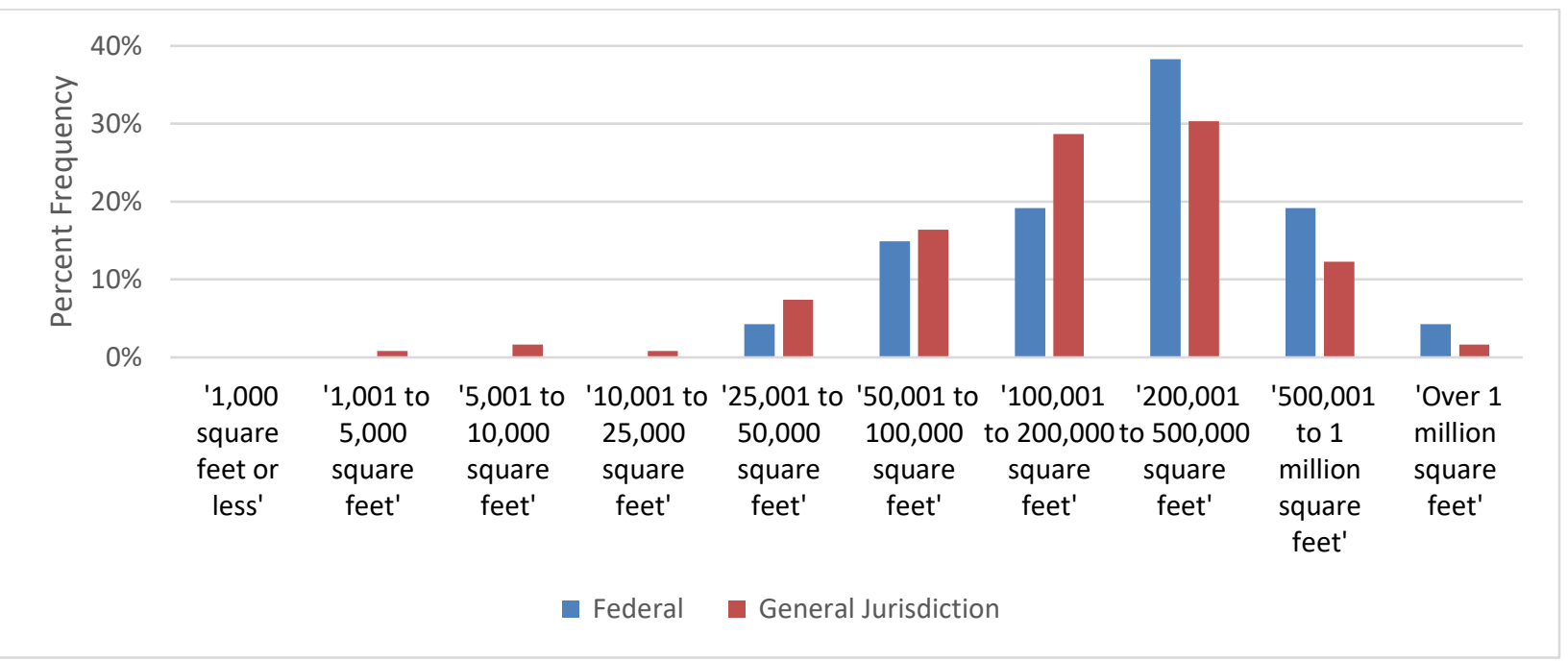

Figure 23. Percentage frequency of building gross square feet (increasing bin size).

(Source: Hardenbergh 1992, Hardenbergh and Phillips 2001, and Yeh et al. 2010a)

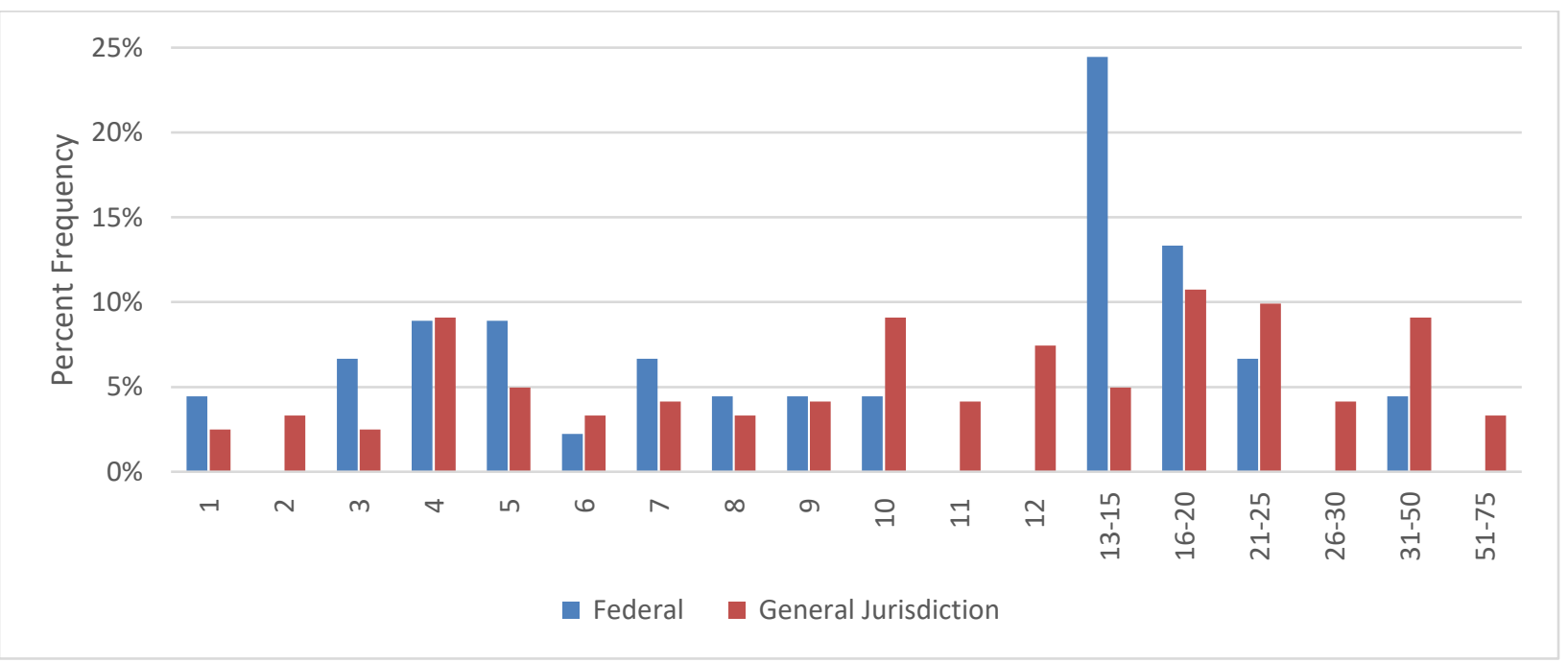

Figure 24. Percentage frequency of number of courtrooms.

(Source: Hardenbergh 1992, Hardenbergh and Phillips 2001, and Yeh et al. 2010a) 
While we use the project technical data to understand courthouse properties for building energy modeling, it should be noted that these projects were competitively selected, and not sampled, so derived statistics may not be representative of federal and state courthouse populations. Figure 25 shows a scatter plot of gross floor area versus number of courtrooms for 45 federal and 121 state courthouses, and indicates $15,900 \mathrm{sq} \mathrm{ft}$ per courtroom for general jurisdiction state courthouse and 27,500 sq ft per courtroom for federal courthouse.

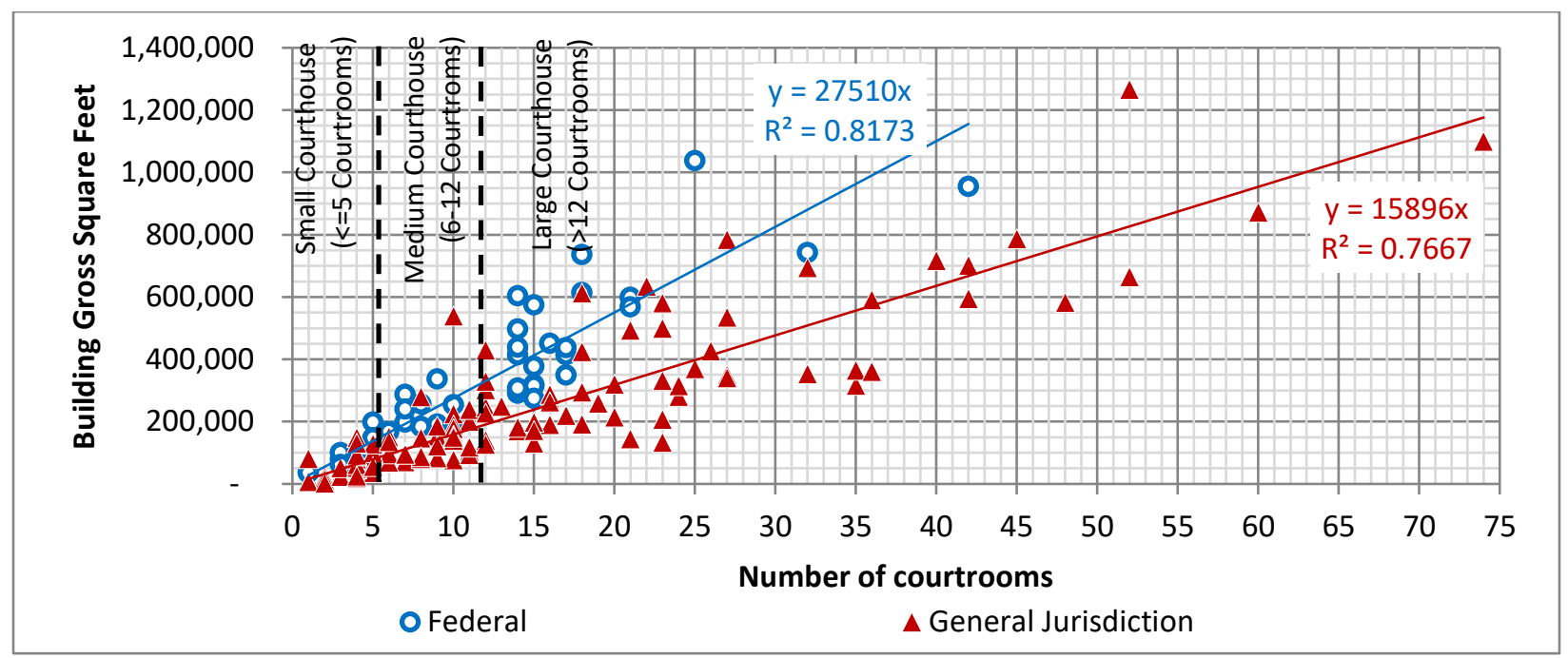

Figure 25. Correlation between number of courtrooms and building gross square feet.

(Source: Hardenbergh 1992, Hardenbergh and Phillips 2001, and Yeh et al. 2010a)

\subsection{BUILDING SHAPE}

According to 2012 CBECS microdata (EIA 2015), wide rectangle is the predominant building shape for courthouse. As shown in Figure 26, 66\% of courthouses have wide rectangle footprint, which cover 59\% of total courthouse floor area in the United States.

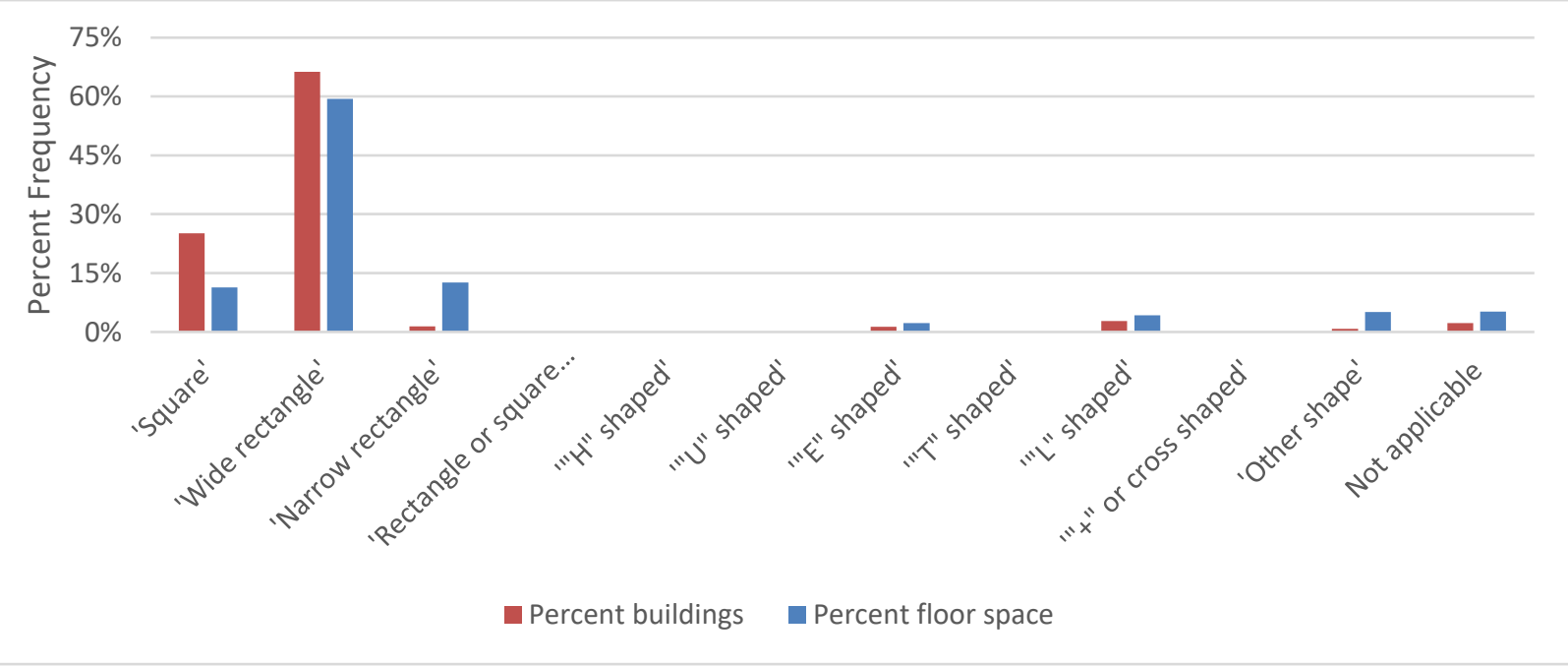

Figure 26. Percentage frequency of courthouse building shape. (Source: EIA 2015) 
For more specific data about the building length and width to determine the building aspect ratio, we use 1992 CBECS microdata (EIA 1996). Out of 83 sample buildings listed under the public order and safety category ${ }^{11}$ representing 60,000, 57 samples representing 44,224 buildings are rectangular buildings with floor area ranging of 1,000-1 million sq ft. Figure 27 shows the bin-average aspect ratio (black ' $x$ ' markers) of rectangular buildings in different floor area bins. The bin percent frequency by number of buildings and by floor area are also plotted. It shows that $65 \%$ of buildings ( $70 \%$ of total building area in that category) have an aspect ratio between 2:1 to 2.4:1. Buildings less than 5,000 sq ft or more than 1 million sq ft have a smaller aspect ratio (i.e., 1.65: 1 and 1.4:1).

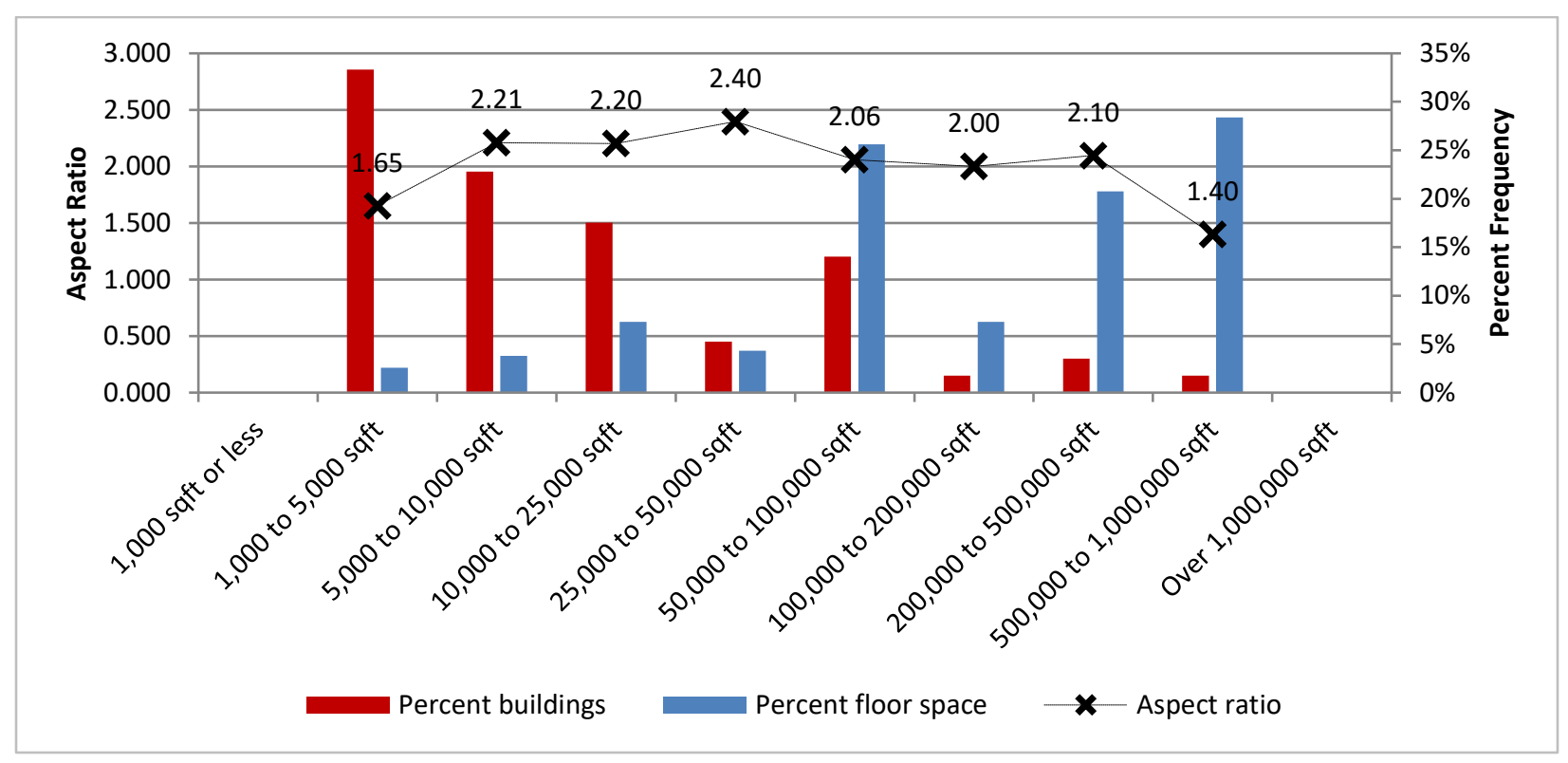

Figure 27. Aspect ratio of buildings under the Public Order and Safety category. (Source: EIA 1996)

\subsection{NUMBER OF FLOORS}

According to 2012 CBECS microdata (EIA 2015), $47 \%$ of courthouses in the United States are one-story, as shown in Figure 28. However, they represent only 3\% of total courthouse floor area in the United States. The next most common buildings are three and four-story courthouses; together they represent $31 \%$ of all courthouses and $22 \%$ of total courthouse floor area.

\footnotetext{
${ }^{11}$ It is to be noted that in 1992 CBECS data, buildings are categorized only by the principal building activity (such as, Public Order and Safety), and not by subcategory (such as, courthouse).
} 


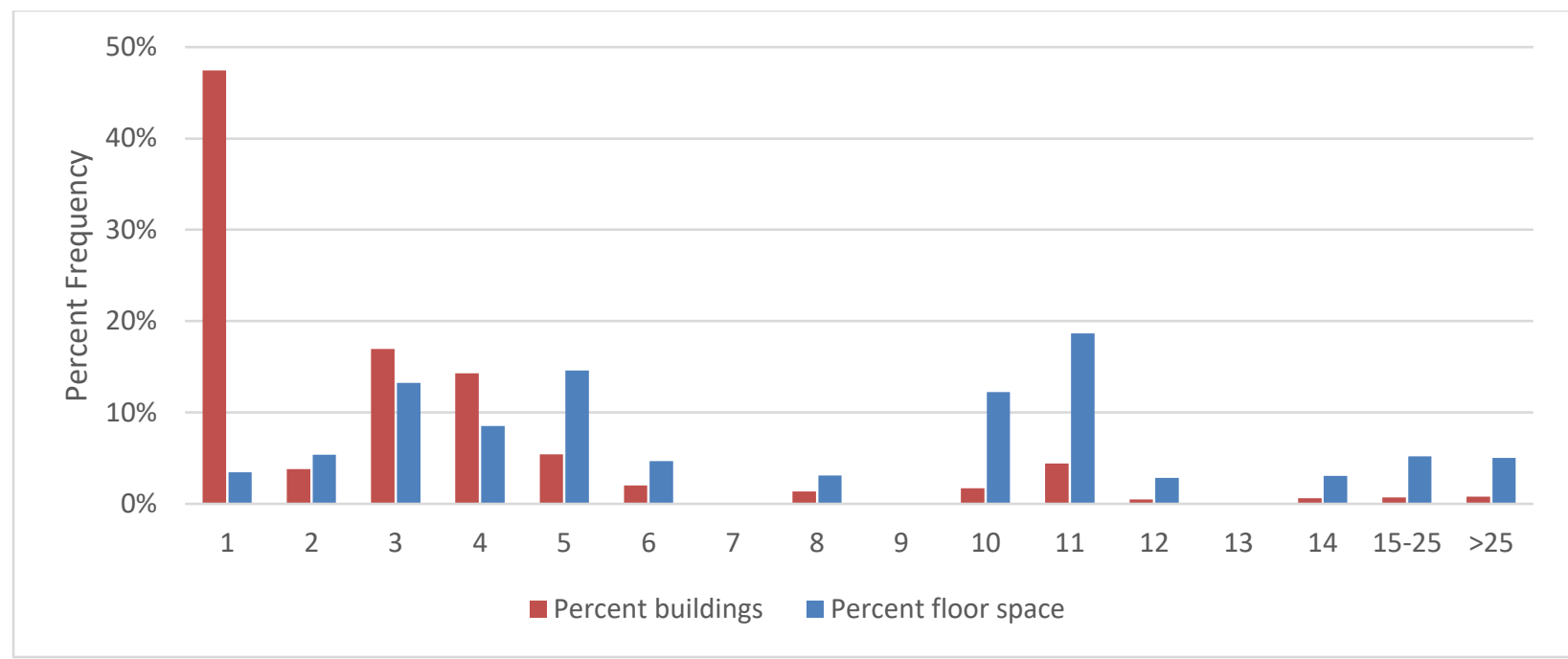

Figure 28. Percentage frequency of courthouse number of floors. (Source: EIA 2015)

\subsection{WINDOWS}

The available resources provide limited information about exterior window area in courthouse buildings. According to the 2012 CBECS microdata, the 11-25\% category for exterior glass percent is the most common (i.e., in $73 \%$ courthouse), as shown in Figure 29.

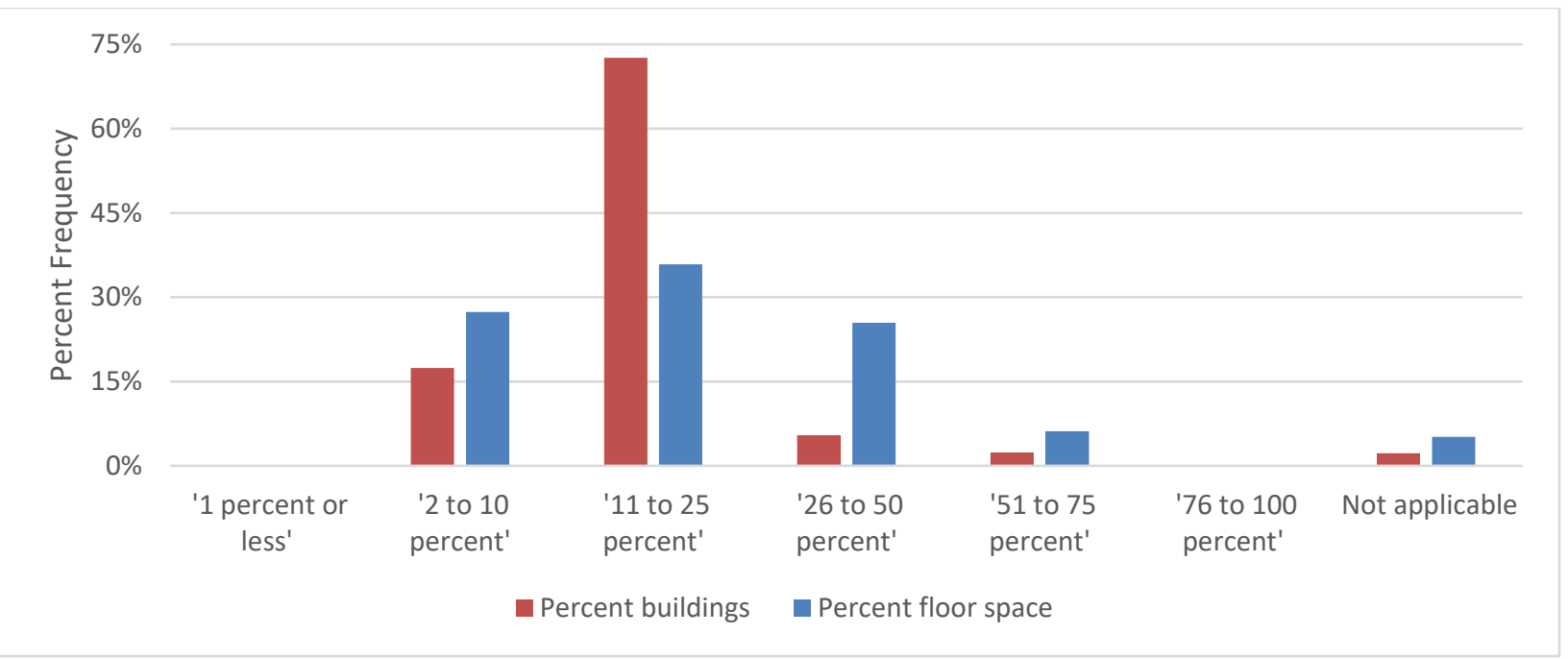

Figure 29. Percentage frequency of percent exterior glass in courthouse. (Source: EIA 2015)

The GSA Unit Cost Study (GSA n.d.) used 40\% glazing for the fenestration system for federal courthouse.

The retrospective book series indicates a recent design trend of allowing more natural light in all spaces including courtrooms, as opposed to that in older courthouse buildings with less window area and courtrooms with no windows. As discussed in NCSC (2010), "Meanwhile, the courtroom modules tended to be entombed spaces removed inboard from the building perimeter by private circulation routes and concerns about security." 
"The projects in [NCSC (2010)] demonstrate a clear evolution beyond those earlier priorities suggesting that the courtroom design challenges that surfaced in the 1990's have now been worked out and the emergence of a new priority that involves the introduction of natural light. There were examples of modern courtrooms with natural light in [Hardenbergh et al. (1991) and Hardenbergh and Phillips (2001)], but the emphasis upon light has become more widespread as a primary goal. A variety of techniques for bringing light into the courtroom directly or on a borrowed basis are illustrated in the projects and reflect appreciation for the virtues of natural light in often stressful settings."

Further,

"Similar advances are being made with the design of public space that reflects greater awareness of the need for safe, easily comprehensible corridors and light-filled waiting areas."

Yeh et al. (2010a) also emphasizes on the recent trend towards designing courthouses with more glass, even in the courtrooms, Affirming Transparency and Openness, "Rejecting the Architecture of Fear."

For determining the placement of windows in different spaces in the courthouse (e.g., presence, size, sill height), one relevant consideration is found in California Trial Courts Facilities Standards (2011), which specifies that for courtrooms, chambers and jury assembly rooms, windows with direct line of sight from public areas, circulation zones, and parking garages, should be minimized to prevent observation of activities, threat exposure, or communication with courthouse occupants.

\subsection{NUMBER OF ELEVATORS}

The 2012 CBECS microdata (EIA 2015) lists number of elevators in the building. Figure 30 plots the number of elevators versus (a) building square footage and (b) number of floors. The number of floors for each data point is marked in Figure 30(a). The plot shows that, in general, the number of elevators is roughly correlated with the building square footage with a maximum of 12 elevators. For medium and large courthouses, such dependence is less discernable. Likewise, Figure 30(b) shows that the number of elevators is roughly correlated with number of floors, with a few outlying data points. 


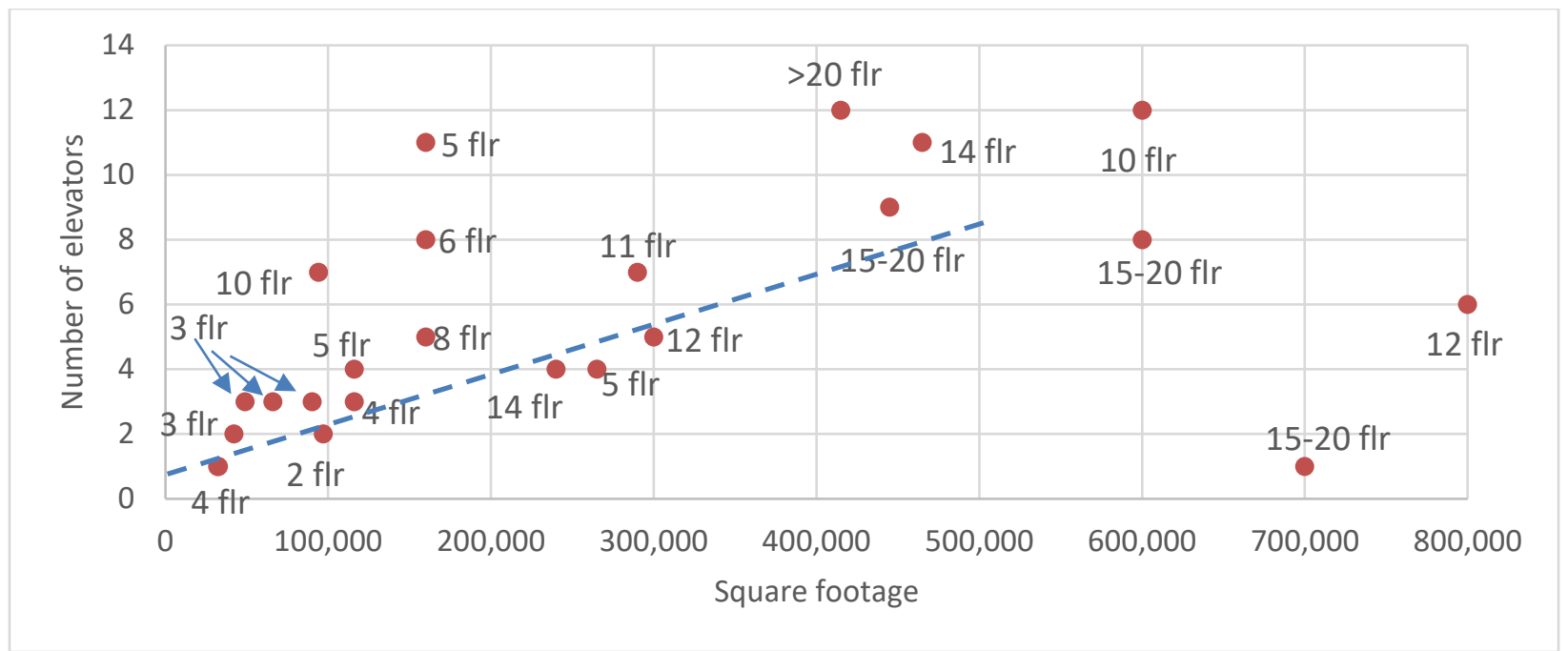

(a)

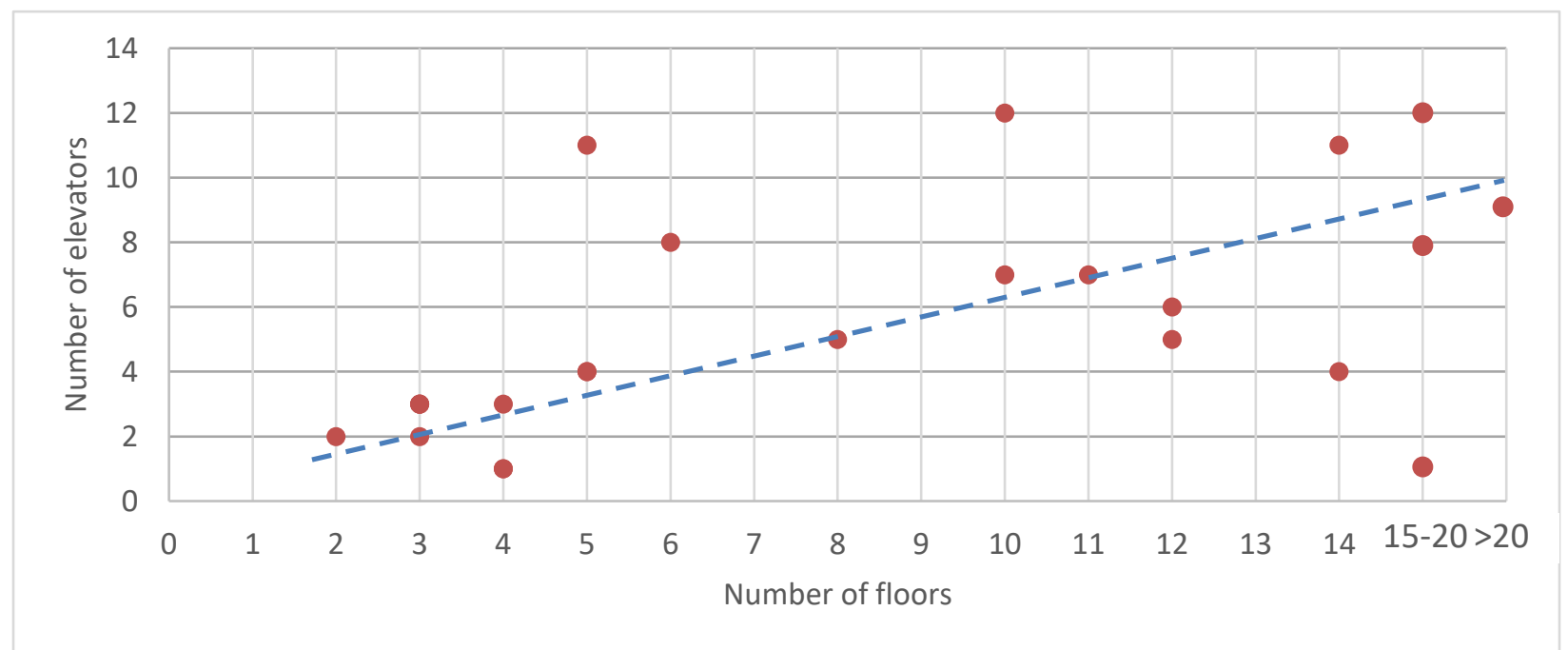

(b)

Figure 30. Number of elevators versus (a) building square footage, (b) number of floors. (Source: EIA 2015)

\subsection{CONSTRUCTION}

GSA (2017a) specifies the following requirements for courthouse

- Building enclosure system: The baseline standard of exterior envelope materials for US Court facilities is precast concrete with limited stone, brick, or other durable materials.

- Interior wall system: Most interior wall partitions will be composed of gypsum board on metal studs, with the exception of detention spaces; Concrete masonry for elevators and plumbing shafts when stacked systematically floor upon floor.

In 2012 CBECS data (EIA 2015), predominant building envelope characteristics for courthouse are as follows: 
- Exterior wall finish: brick, stone, or stucco

- Roofing: Asphalt, fiberglass, or other shingles

- Flat or shallow pitch roof

- Glazing: Single and multilayer glass

GSA Unit Cost Study (GSA n.d.) used the following construction specifications:

- Exterior wall system: precast concrete panels with stucco on the outside

- Exterior basement walls: 12" poured in-place concrete

- Interior walls: two layers of 5/8" gypsum wall board (GWB) on interior face of metal furring; $1 / 2$ " GWB on metal furring over concrete or CMU walls for interior basement walls and all vertical shafts including elevators and stairwells

- Floor and roof construction: composite concrete on 20-gauge steel floor deck

- Roofing: flat roof with built-up roofing; closed cell polystyrene rigid insulation

- Windows: Aluminum frame punched window system

\subsection{FLOOR LAYOUT}

Several floor configurations were found in the courthouse projects documented in the Retrospective book series.

- Single loaded vs double loaded public corridor

- Judges suites on the courtroom floors vs all on a dedicated floor

- Courtroom sharing vs one courtroom per judge

- Location of courtrooms in the center versus on the perimeter

\subsection{SCHEDULE OF BUILDING USE}

According to ASHRAE (2013), courtrooms generally do not have a clear schedule of operation; however, they generally operate between 9 a.m. until approximately noon. Support staff generally work between 8 a.m. and 5 p.m., except in constant occupancy spaces such as marshal areas, jail cells, and other administration areas. Jury areas are generally 9 a.m. to 5 p.m. but may be occupied much longer, depending on the type of trial. According to USCDG (2007), courtrooms may be used during extended hours. However, judges' chambers are routinely in use during evenings and weekends. Audio/visual rooms and server rooms require 24-hour climate control. Clerks' offices operate on flextime and probation offices can have early morning and late evening hours. Other areas that routinely require offhours operation are the trial jury suite and grand jury suite. According to Hardenbergh (2015), there is often a need for after-hours access to some parts of the building. The Commonwealth's Attorney's Office often needs to work after-hours and on weekends. If Juvenile Court Services and Community Corrections are in the courthouse, after-hours access may be required to meet with clients and provide special programs. The Magistrates, if in the courthouse, require 24-hour access seven days a week. Therefore, 
courthouses should be designed to suit operational hours and fluctuating visitors and staff occupancies for maximum energy conservation and optimum controls.

IGA documentation of 31 federal courthouses ${ }^{12}$ provides information regarding occupancy schedules. A number of federal courthouse buildings are open also on Saturdays. This is possibly due to the US Postal Service being one of the tenants of the building. The schedule of operation of these buildings on weekdays is plotted in Figure 31. For five courthouses, the actual time of operation was not provided. Majority of federal courthouse operate from 7 am through $6 \mathrm{pm}$ during weekdays. The average duration of courthouse operation across these courthouses is 11 hours per day.

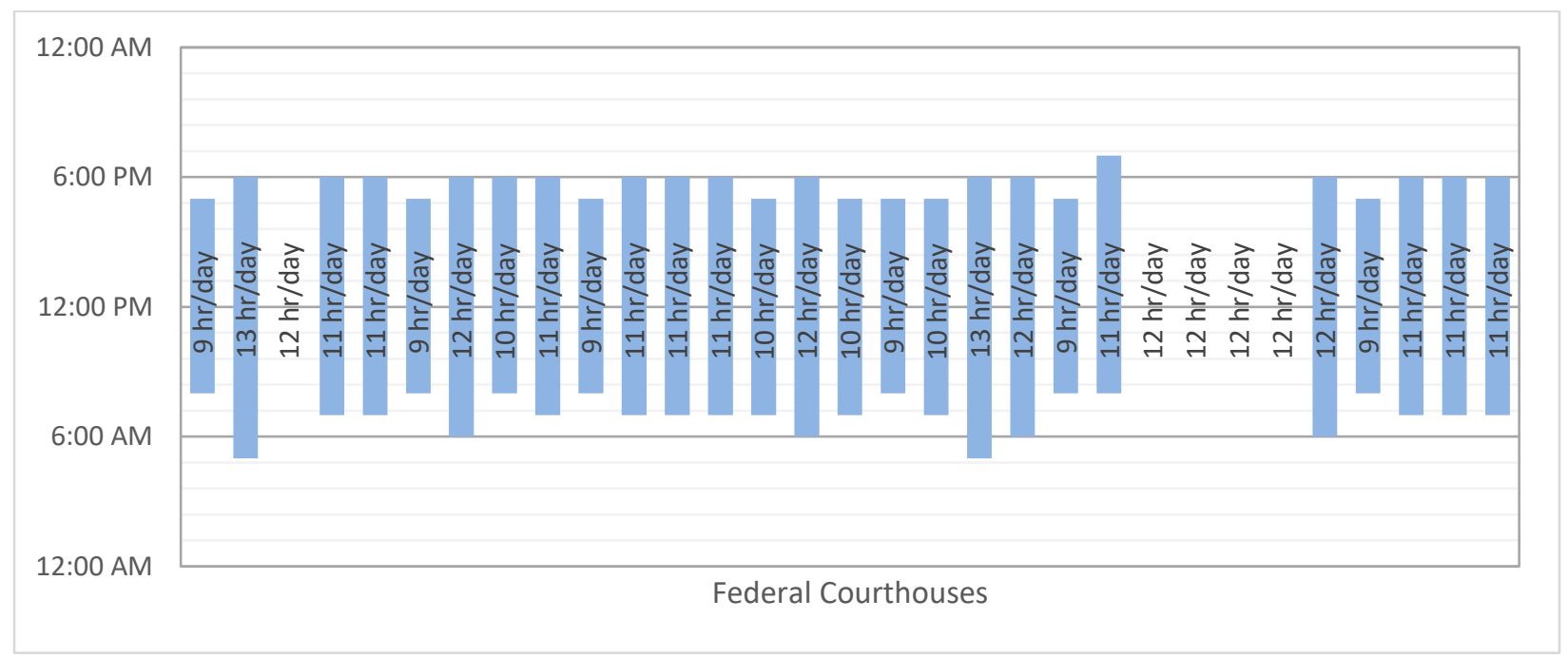

Figure 31. Schedule of operation on weekdays in 31 federal courthouses.

(Source: IGA documentation of federal courthouses)

Figure 32 shows the total hours open per week in the 26 sample courthouses included in 2012 CBECS data along with their percent weight. Two outlier courthouses are listed as operating 168 hours per week (i.e., 24 hours per day). Accounting for the sample weights, average hours open per week is 53.2 hours per week (i.e., 10.6 hours per day).

\footnotetext{
${ }^{12}$ IGA documentation under the FEMP ESPC program contains findings that are deemed business sensitive by the
} project developers and therefore are not publicly available. 


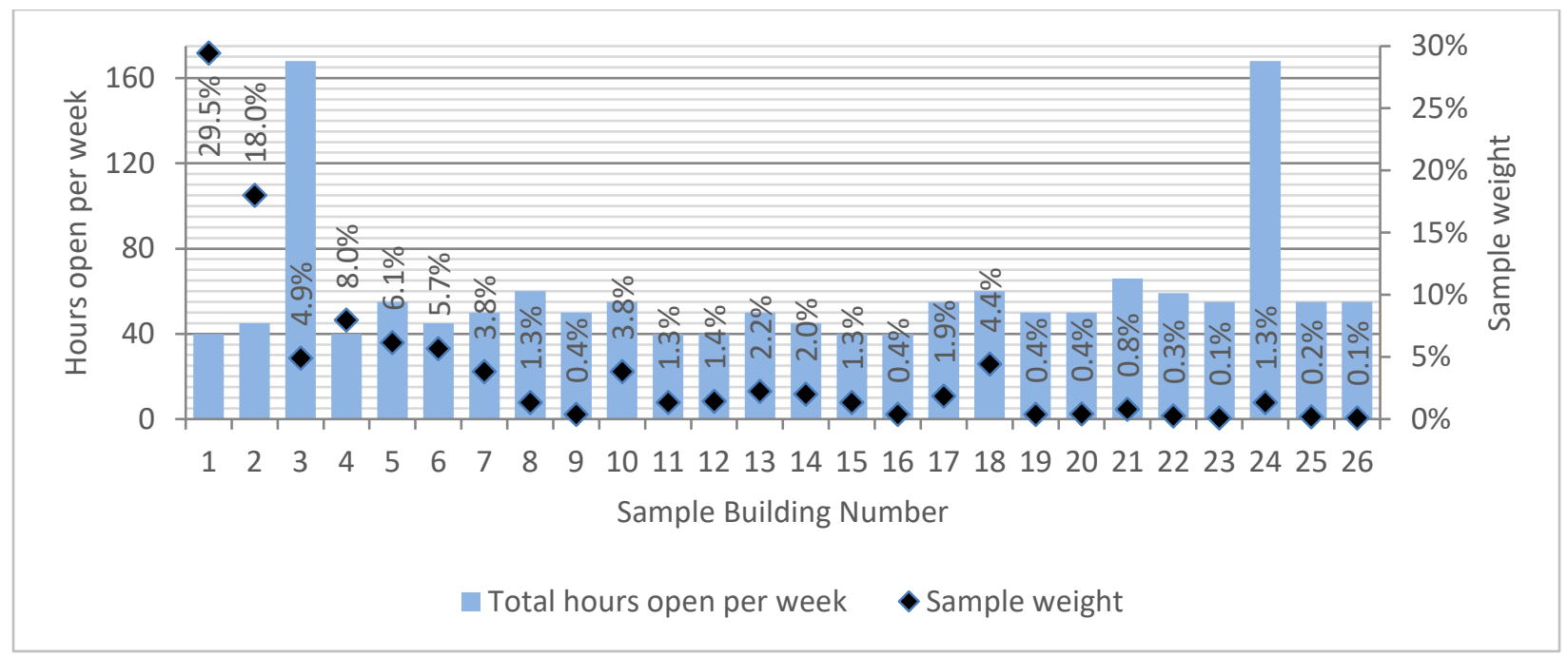

Figure 32. Total hours open per week in courthouses. (Source: EIA 2015)

\subsection{HVAC SYSTEM}

Several data sources for the courthouse HVAC system characteristics were found. The first one is US EIA's 2012 Commercial Building Energy Consumption Survey (CBECS). The micro data set includes 26 representative courthouse buildings, and the data provides main heating and cooling equipment types, heating source, chiller type, ventilation systems, etc.

The other source is the IGA findings for 31 federal courthouses under US DOE FEMP ESPC awards ${ }^{13}$, which includes 31 federal courthouse buildings from 4 states (AR, LA, NM, and TX). Each IGA report contains the existing condition and characteristics of the building including HVAC systems and control, energy use baseline, and proposed ECMs.

Lastly, the ASHRAE Handbook HVAC Application also provides several requirements for HVAC system applications for courthouses. The Chapter 9 of the Handbook presents the HVAC design criteria, system requirements and additional requirements by space type.

\subsubsection{Main heating source and heating equipment}

According to 2012 CBECS microdata (EIA 2015), natural gas (81\%) is the dominant heating source, followed by electricity (7\%) (Figure 33). The district heating (8\%) is slightly higher than the electricity when it combines district steam and hot water system. IGA documentation of 31 federal courthouses also confirms that most buildings use natural gas for main heating source, while one building uses district hot water.

The 2012 CBECS data also shows 52\% of courthouse buildings use boilers as the main heating system, followed by packaged central unit (30\%) (Figure 34). IGA documentation of 31 federal courthouses also shows that all 31 buildings are equipped with natural gas fired boilers.

\footnotetext{
${ }^{13}$ IGA documentation under the FEMP ESPC program contains findings that are deemed business sensitive by the project developers and therefore are not publicly available.
} 


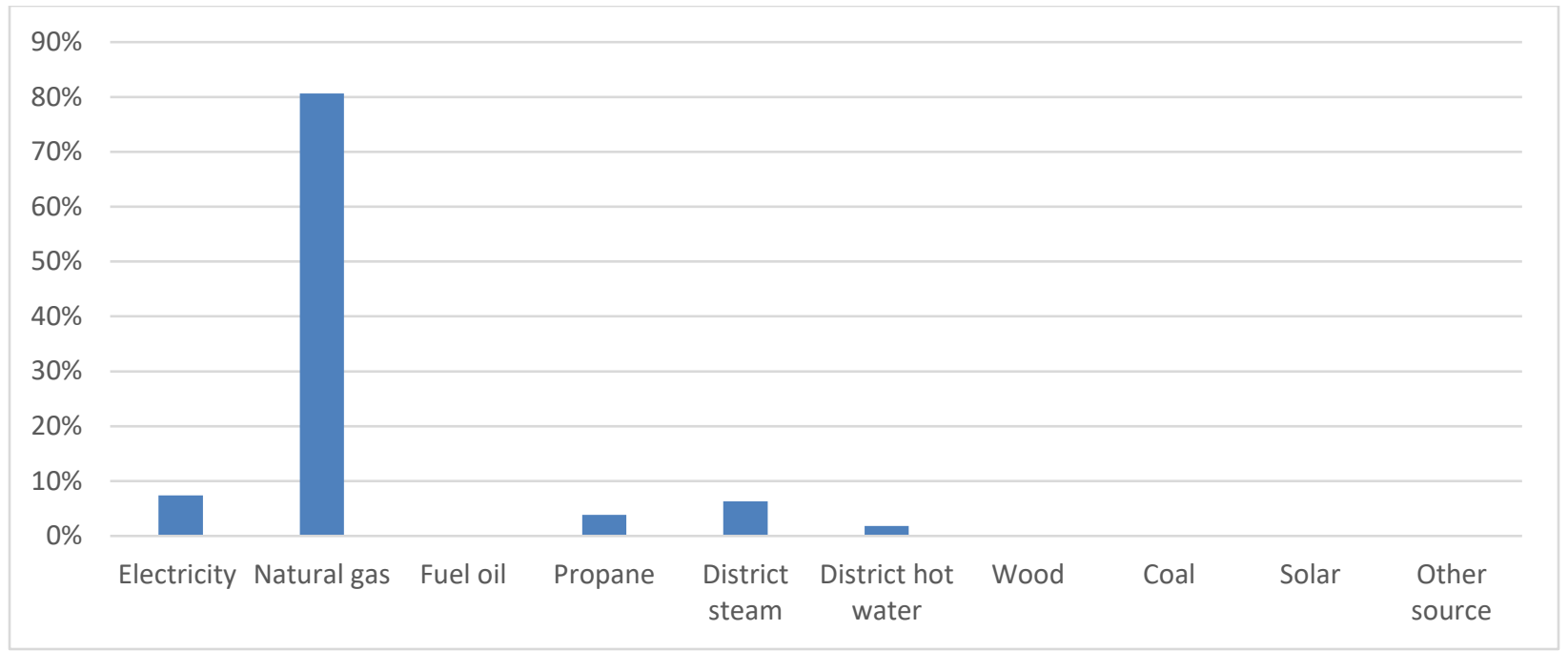

Figure 33. Percent main heating source. (Source: EIA 2015)

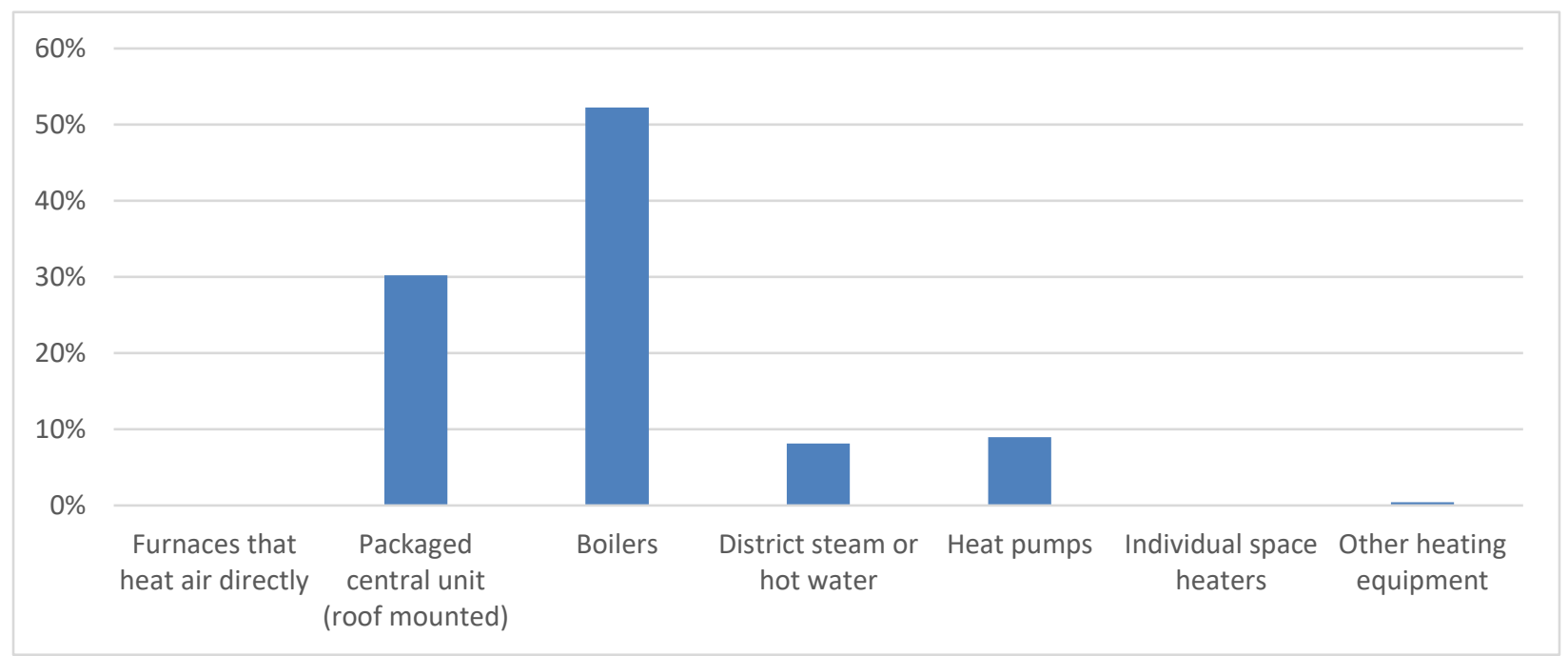

Figure 34. Percent main heating equipment. (Source: EIA 2015)

\subsubsection{Main cooling system type}

According to the 2012 CBECS, the main cooling system type for the courthouse is central chillers (55\%) followed by heat pump cooling (20\%) which can be found in packaged DX cooling unit (Figure 35) followed by residential type central air conditioners (11\%). The same source also specifies $95 \%$ of the chillers are water cooled. IGA documentation of 31 federal courthouses also confirms that the main cooling system is central chillers, while a smaller portion of individual rooms are provided with packaged terminal unit or residential type air conditioners. 


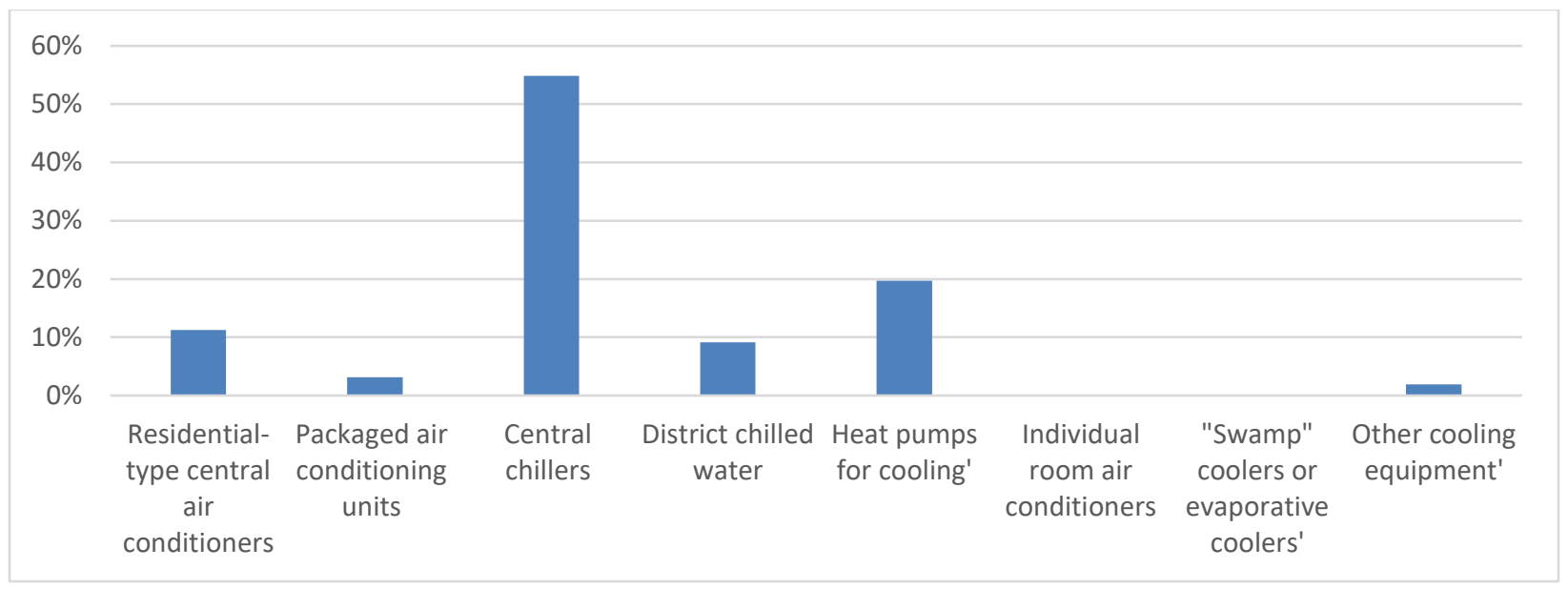

Figure 35. Percentage main cooling system. (Source: EIA 2015)

\subsubsection{Air Handling Unit Type}

Typical air handling unit (AHU) type for courthouse can be inferred from the cooling and heating ventilation system type defined in 2012 CBECS. The major cooling ventilation type for courthouse buildings are constant air volume (CAV) and variable air volume (VAV) systems (Figure 36). The percent VAV system type (44\%) is slightly higher than the one for CAV system type (42\%). IGA documentation of 31 federal courthouses also show that there are many buildings with CAV and VAV systems. In many cases, the building's heating and cooling is provided with both CAV and VAV systems.

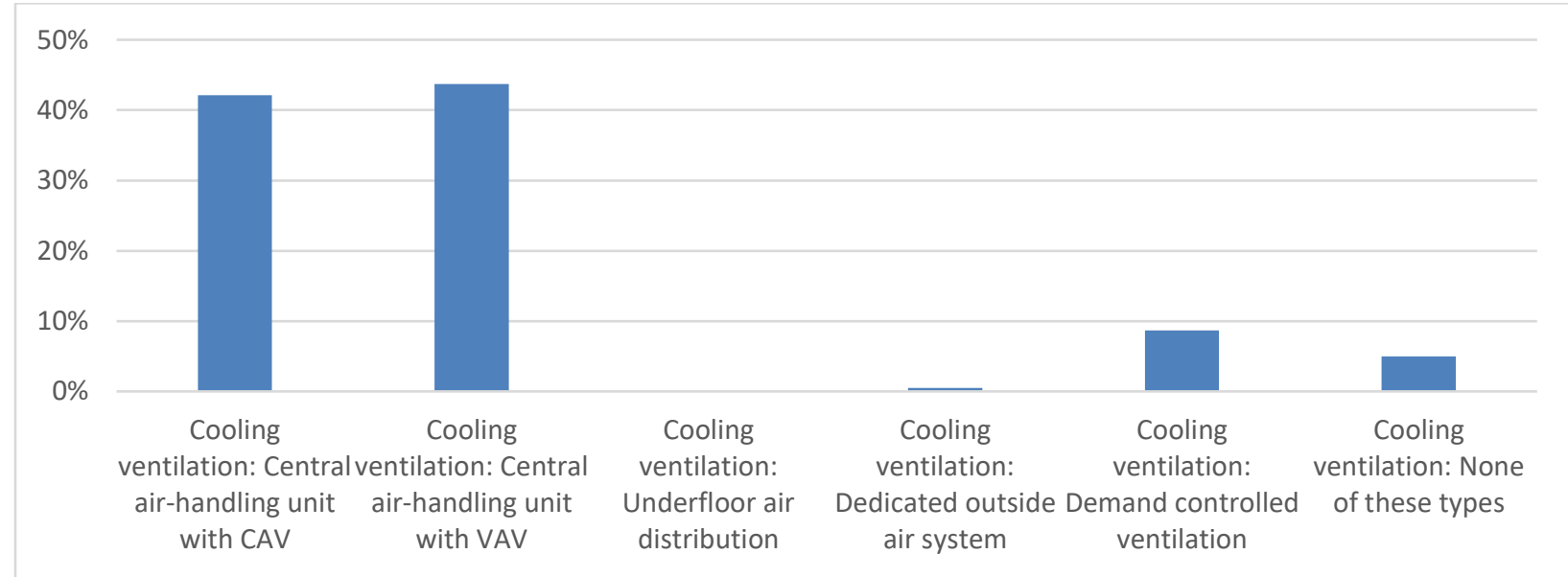

Figure 36. Percentage cooling ventilation system. (Source: EIA 2015) 


\section{PROTOTYPE MODELING CHARACTERISTICS}

This chapter presents recommendations for the building and system characteristics required to develop the prototype courthouse energy model. Overall, we propose a general jurisdiction trial courthouse (one of the state district court types) for the prototype courthouse model. The spaces include courtrooms, judges' chamber suites, clerks, court administration offices, jury areas, detention areas, court security, and prosecutor's office.

\subsection{BUILDING FORM}

\subsubsection{Floor Area, Number of Floors, and Building Shape}

Based on Section 3.1, we recommend the prototype courthouse to be a 3-story, 4-courtroom building. We developed the area programming for a 4-courtroom courthouse to target a 69,400 sq ft floor area (i.e., the average area in 2012 CBECS, as discussed in Sections 1.3.2).

We developed the floor layout considering the width, floor area, and adjacency requirements for different spaces (such as courtrooms and supporting spaces, judges' chambers, deliberation rooms, court-floor in custody holding area, and public and private corridors), aiming for 2.08:1 aspect ratio (i.e., the binaverage aspect ratio for 50,000-100,000 sq ft courthouse, as discussed in Section 3.2,).

Considering equal areas on all three floors, the total floor area of the building resulted in $69,324 \mathrm{sq} \mathrm{ft}$ with a footprint of $218 \mathrm{ft} \times 106 \mathrm{ft}$.

\subsubsection{Window Fraction and Window Locations}

Based on Section 3.4, we recommend 15-18\% window-to-wall area ratio (i.e., the average of 11-25\% binrange, which is associated with maximum percent frequency, according to 2012 CBECS data). We recommend punched window system with no exterior shading and sill height varying between 30 " and 48 " depending on the design guidelines to avoid direct sightline in certain spaces (as discussed in Section 3.4). The distribution of windows on different orientations will be determined after placement of windows for different spaces.

\subsubsection{Floor Height}

Based on Section 2.5.2, we recommend floor to floor height be 14 feet for basement and first floor, and 20 feet for the courtroom floor, which includes a 4 foot ceiling plenum on each floor.

\subsubsection{Layout of Spaces}

With the building shape and area and functional space requirements in view, the floor layout was developed in consultation with courthouse design experts (personal communication with Michael Griebel, Henry Pittner, Don Hardenburgh, and Bob Schwartz). Figure 37, Figure 38 and Figure 39 show the space layout of basement, first floor and second floor.

The building is planned with a typical courtroom floor housing courtrooms and supporting spaces, judges' chambers and court floor holding areas; first floor with a public entrance/lobby, clerk's office, court administration office, prosecuting attorney's offices, jury assembly area, and law library with a basement for secured parking for judges, central holding area, building management, and support areas. 


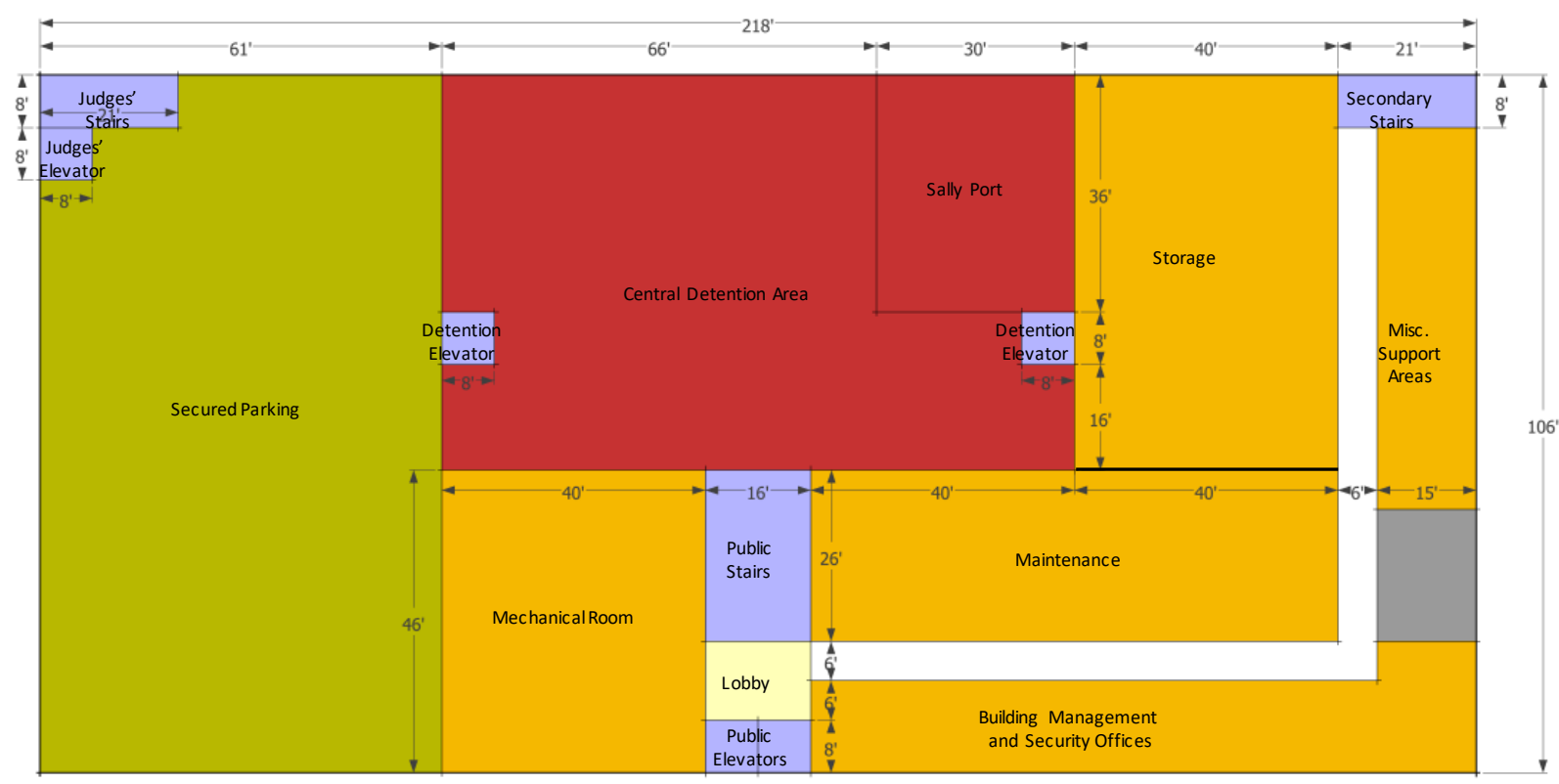

Figure 37. Prototype courthouse: basement floor layout.

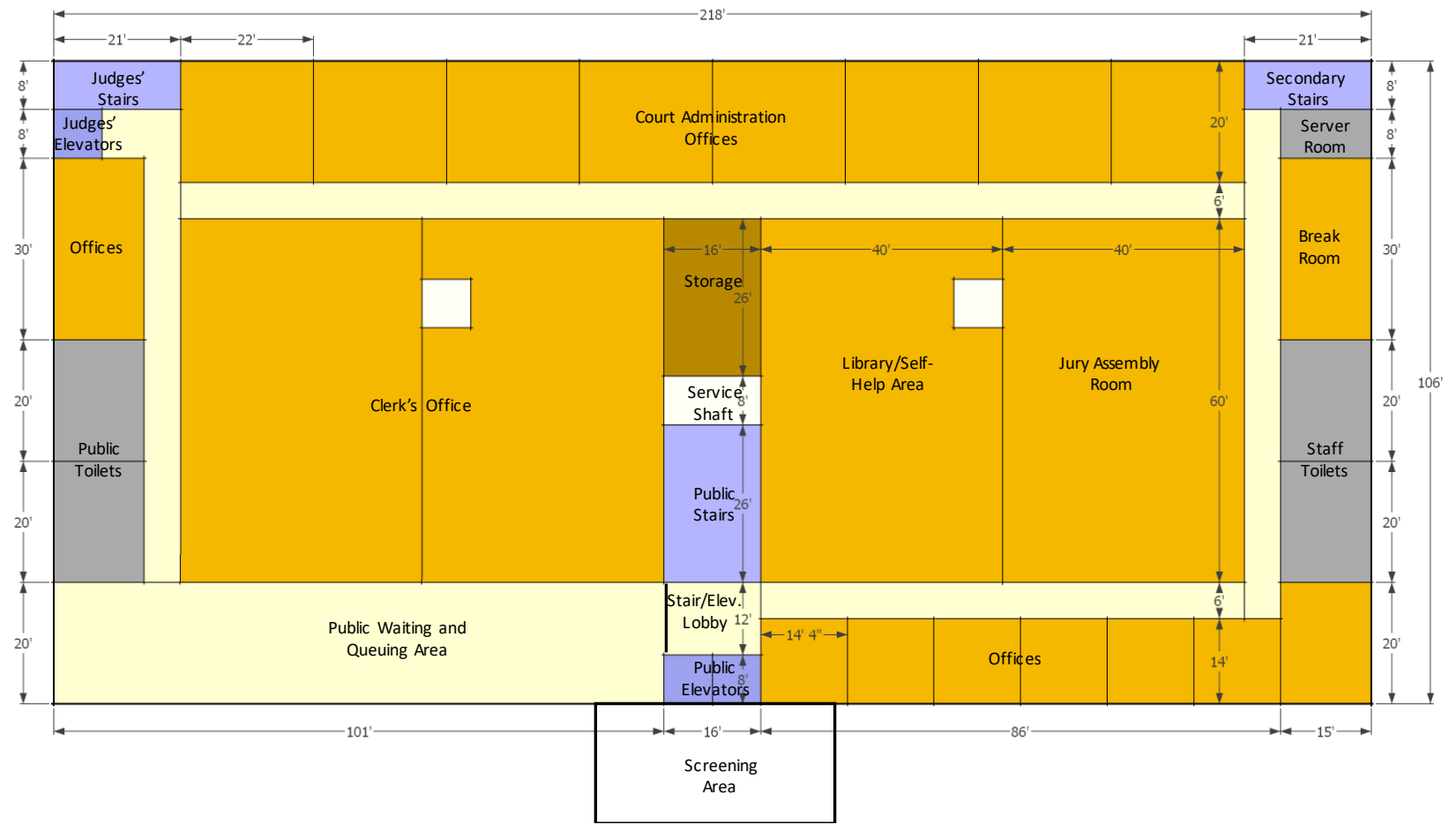

Figure 38. Prototype courthouse: first floor layout. 


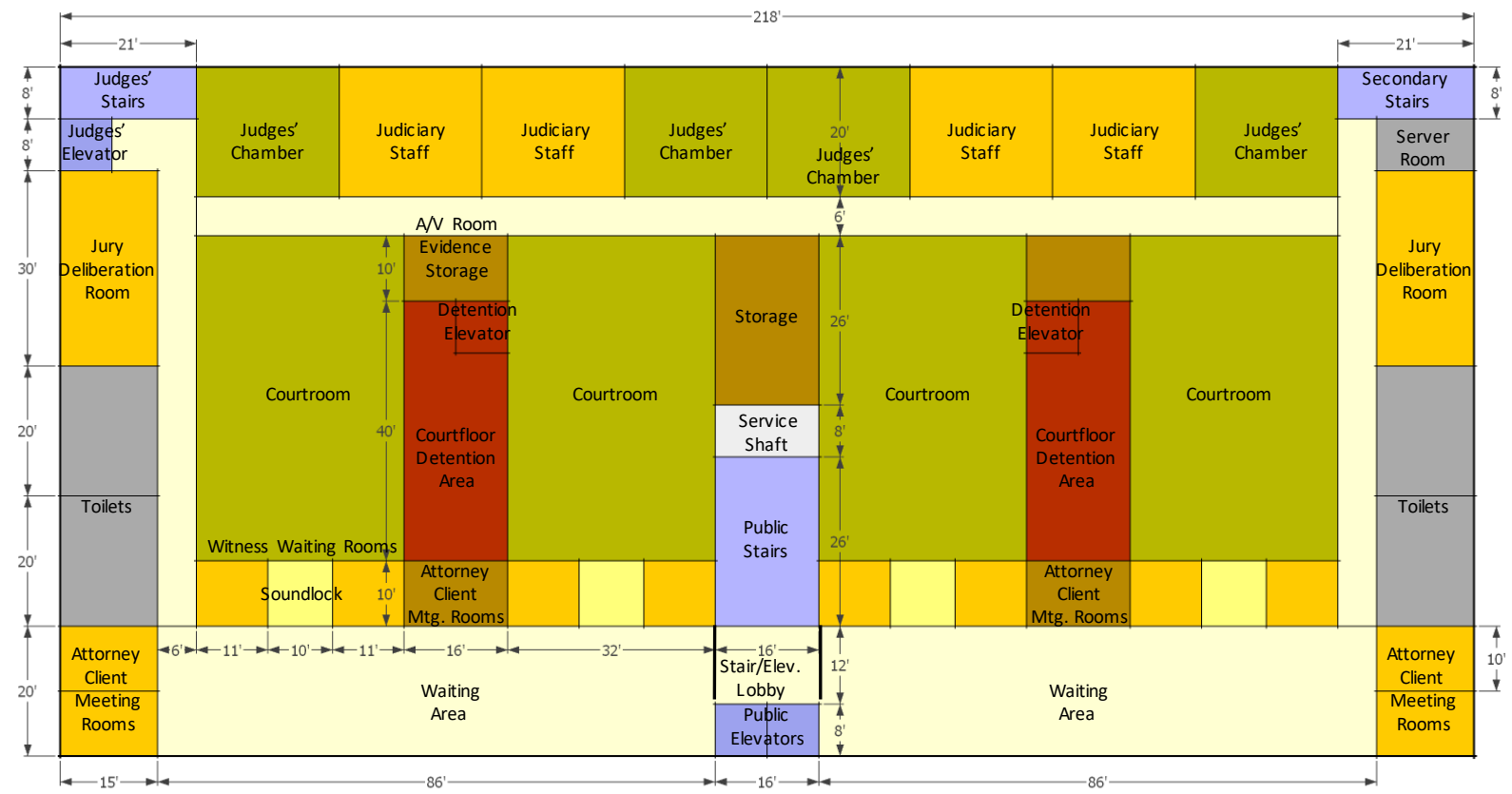

Figure 39. Prototype courthouse: second floor layout.

Table 4 shows the area program for the proposed prototype courthouse, which can be summarized as below:

- 4 courtrooms, $69,324 \mathrm{sq} \mathrm{ft}(17,331 \mathrm{sq} \mathrm{ft} /$ courtroom)

- 2 floors plus basement (23,108 sq ft/floor)

Table 4. Prototype courthouse area program.

\begin{tabular}{|l|c|r|r|}
\hline \multicolumn{1}{|c|}{ Space categories } & No. & Space Area (sq ft) & Total Area (sq ft) \\
\hline Mechanical Room & 1 & 1,840 & 1,840 \\
\hline Maintenance & 1 & 2,080 & 2,080 \\
\hline Storage & 1 & 2,400 & 2,400 \\
\hline Building Management and Security Offices & 1 & 1,204 & 1,204 \\
\hline Miscellaneous Support Spaces & 1 & 1,470 & 1,470 \\
\hline Central Holding + Sally Port & 1 & 5,632 & 5,632 \\
\hline Secured Parking & 1 & 6,234 & 6,234 \\
\hline Lobby & 1 & 192 & 192 \\
\hline Corridor & 1 & 984 & 984 \\
\hline Judges' Stairs & 1 & 168 & 168 \\
\hline Secondary Stairs & 1 & 168 & 168 \\
\hline Public Stairs & 1 & 416 & 416 \\
\hline Public elevator & 2 & 64 & 128 \\
\hline Judges' Elevator & 1 & 64 & 64 \\
\hline Detention Elevators & 2 & 64 & 128 \\
\hline Basement total & & & $\mathbf{2 3 , 1 0 8}$ \\
\hline Public Waiting and Queuing Area & 1 & 2,020 & 2,020 \\
\hline Clerk's Office & 1 & 4,736 & 4,736 \\
\hline
\end{tabular}


Table 4. Prototype Courthouse Area Program (continued).

\begin{tabular}{|c|c|c|c|}
\hline Space categories & No. & Space Area (sq ft) & Total Area (sq ft) \\
\hline Jury assembly area & 1 & 2,400 & 2,400 \\
\hline Library & 1 & 2,336 & 2,336 \\
\hline Offices (other agencies) & 1 & 1,204 & 1,204 \\
\hline Offices (other agencies) & 1 & 300 & 300 \\
\hline Break room & 1 & 450 & 450 \\
\hline Offices (other agencies) & 1 & 450 & 450 \\
\hline Court Administration & 1 & 3,520 & 3,520 \\
\hline Record storage & 1 & 416 & 416 \\
\hline Toilets & 2 & 600 & 1,200 \\
\hline Server Room & 1 & 120 & 120 \\
\hline Service Shaft & 1 & 128 & 128 \\
\hline Lobby & 1 & 192 & 192 \\
\hline Corridor & 1 & 2,564 & 2,564 \\
\hline Judges' Stairs & 1 & 168 & 168 \\
\hline Secondary Stairs & 1 & 168 & 168 \\
\hline Public Stairs & 1 & 416 & 416 \\
\hline Public elevator & 2 & 64 & 128 \\
\hline Judges' Elevator & 1 & 64 & 64 \\
\hline Detention Elevators & 2 & 64 & 128 \\
\hline First floor total & & & 23,108 \\
\hline Courtrooms & 4 & 1,600 & 6,400 \\
\hline Sound lock, attorney client/witness waiting rooms & 4 & 320 & 1,280 \\
\hline $\mathrm{A} / \mathrm{V}$ and evidence storage room & 2 & 160 & 320 \\
\hline Courtroom waiting area & 2 & 1,720 & 3,440 \\
\hline Attorney client conference rooms & 4 & 150 & 600 \\
\hline Attorney client conference rooms & 2 & 160 & 320 \\
\hline Courtfloor Detention Area & 2 & 576 & 1,152 \\
\hline Jury deliberation rooms & 2 & 450 & 900 \\
\hline Judges' Suite & 4 & 880 & 3,520 \\
\hline Storage & 1 & 416 & 416 \\
\hline Toilets & 2 & 600 & 1,200 \\
\hline Server Room & 1 & 120 & 120 \\
\hline Service Shaft & 1 & 128 & 128 \\
\hline Lobby & 1 & 192 & 192 \\
\hline Corridor & 1 & 2,048 & 2,048 \\
\hline Judges' Stairs & 1 & 168 & 168 \\
\hline Secondary Stairs & 1 & 168 & 168 \\
\hline Public Stairs & 1 & 416 & 416 \\
\hline Public elevator & 2 & 64 & 128 \\
\hline Judges' Elevator & 1 & 64 & 64 \\
\hline Detention Elevators & 2 & 64 & 128 \\
\hline Second floor total & & & 23,108 \\
\hline Calculated BGSF & & & 67,324 \\
\hline
\end{tabular}




\subsection{STRUCTURE}

Based on Section 3.6, we recommend the following construction characteristics for the prototype model:

- Exterior walls: Mass walls (precast concrete panels) with wall insulation, stucco on the outside, gypsum wall board on metal furring on the inside;

- Basement walls: Mass walls (12" poured-in-place concrete) with insulation; gypsum wall board on metal furring on the inside;

- Roof: Horizontal, built-up roof with roof membrane, insulation and metal decking

- Floors: Concrete on metal deck

- Interior partition walls: Metal stud walls with acoustic insulation filling and 5/8" gypsum wall board; concrete walls for vertical shafts including stairwells with gypsum wall board on metal furring;

- Windows: Hypothetical window with weighted U-factor and SHGC

- Thermal properties of all envelope systems: based on ASHRAE Standard 90.1.

\subsection{HVAC SYSTEM AND CONTROL}

\section{System Type}

Based on the data described in Section 3.9, the prototype HVAC system is defined as following:

- Heating type: gas fired boiler

- Cooling type: air-cooled chiller

- Distribution and terminal units: VAV terminal box with damper and hot-water reheating coil

- System sizes (chiller, boiler, zone reheating, airflow) will be auto sized.

- Economizers, Demand control ventilation, Energy recovery: Those will be determined per requirements in ASHRAE Standard 90.1

- Pump type: Primary chilled water (CHW) pumps: constant speed; secondary CHW pump: variable speed; cooling tower pump: variable speed; service water heating $(\mathrm{SWH})$ : constant speed; hot water (HW) pump: variable speed

- Rated pump head and pump power assumptions as specified in ASHRAE Standard 90.1, Appendix G

\section{Control}

- Thermostat setpoint: $74^{\circ} \mathrm{F}$ Cooling $/ 72^{\circ} \mathrm{F}$ Heating 
- Thermostat setback: $85^{\circ} \mathrm{F}$ Cooling $/ 60^{\circ} \mathrm{F}$ Heating

- Humidifier will be used to maintain the RH to be 20 to $35 \%$ during winter season

- Supply air temperature: Maximum $104^{\circ} \mathrm{F}$, Minimum $55^{\circ} \mathrm{F}$

- Chilled water supply temperature: $44^{\circ} \mathrm{F}$

- Hot water supply temperature: $180^{\circ} \mathrm{F}$

\section{Air Distribution}

Based on size and complexity of the building, we recommend air distribution systems to be semi-custom air-handling units (AHU) or custom-designed, built-up central air-handling systems. Blow-through type AHUs are preferred.

\subsection{INTERNAL LOADS AND MISCELLANEOUS LOADS}

- Occupancy, lighting loads, and plug loads: Based on thermal zone-specific requirements in codes and standards, supplemented by specifications in design guidelines (as discussed in Section 2.5.3)

- Elevators: five hydraulic elevators including two public elevators, two detention elevators, one judges' elevator;

- Exterior lighting: peak power based on design assumptions for façade, parking lot, entrance, etc. and requirements in codes or standards 


\section{BIBLIOGRAPHY}

ASHRAE. 2015. 2015 ASHRAE Handbook - HVAC Applications. Atlanta, GA: ASHRAE.

Building Energy Codes Program. 2016. Commercial Prototype Building Models. US Department of Energy, Energy Efficiency and Renewable Energy. https://www.energycodes.gov/development/commercial/prototype models

EIA. n.d. CBECS Building Type Definitions. US Energy Information Administration. https://www.eia.gov/consumption/commercial/building-type-definitions.php

EIA. 2016. 2012 CBECS Building Activity Subcategory Examples and Definitions. US Energy Information Administration. https://www.eia.gov/consumption/commercial/data/2012/bc/pdf/pbaplus\%20examples\%20and\%20de finitions.pdf

GSA. 2016. State of the Portfolio FY16 Snapshot. US General Services Administration. https://www.gsa.gov/portal/category/22180.

Deru, M., K. Field, D. Studer, K. Benne, B. Griffith, P. Torcellini, B. Liu, M. Halverson, D. Winiarski, M. Rosenberg, M. Yazdanian, J. Huang, and D. Crawley. 2011. US Department of Energy Commercial Reference Building Models of the National Building Stock. NREL/TP-5500-46861. Golden, CO: National Renewable Energy Laboratory.

\section{$\underline{\text { Courthouse Design Guides }}$}

Phillips, T.S. and M.A. Griebel. 2003. Building Type Basics for Justice Facilities. Indianapolis, IN: Wiley.

Hardenbergh, D., R. Tobin, and C.M. Yeh. 1991. The Courthouse: A Planning and Design Guide for Court Facilities. Williamsburg, VA: National Center for State Courts. https://ncsc.contentdm.oclc.org/digital/collection/facilities/id/74/

The Virtual Courthouse: A Guide to Planning and Design [electronic]. n.d. National Center for State Courts. http://courthouseplanning.ncsc.wikispaces.net

Wong, F.M. (ed.). 2001. Judicial Administration and Space Management: A Guide for Architects, Court Administrators, and Planners. Gainesville, FL: University Press of Florida.

The American Courthouse: Planning and Design for the Judicial Process. 1973. Ann Arbor, MI: Institute of Continuing Legal Education.

U.S. Courts Design Guide (USCDG). 2007. Washington, D.C.: Judicial Conference of the United States.

GSA. 2017a. Facilities Standards for the Public Buildings Service, PBS-P100. Chapter 8 Design

Standards for U.S. Court Facilities. US General Services Administration. https://www.gsa.gov/realestate/design-construction/architecture-engineering/facilities-standards-p100-overview alt: https://www.wbdg.org/ffc/gsa/criteria/pbs-p100

GSA. n.d. GSA Construction Criteria for Courtroom. From GSA Unit Cost Study. pp.20.1-9. https://www.wbdg.org/FFC/GSA/gsa_constr_criteria_courtroom.pdf 
GSA. n.d. Shell and Core: Courthouse. From GSA Unit Cost Study. pp.C1-C35. US General Services Administration. https://www.wbdg.org/files/pdfs/gsa usc shell courthouse.pdf alt: https://www.wbdg.org/FFC/GSA/gsa_usc_shell_courthouse.pdf

Whole Building Design Guide (WBDG). 2016a. Design Recommendation, Space Types, Courthouse: Courtroom. National Institute of Building Sciences. Available at: https://www.wbdg.org/spacetypes/courthouse-courtroom

Whole Building Design Guide (WBDG). 2016b. Design Recommendation, Space Types, Courthouse: Enhanced Office. National Institute of Building Sciences. Available at https://www.wbdg.org/spacetypes/courthouse-enhanced-office

Whole Building Design Guide (WBDG). 2016c. Design Recommendation, Space Types, Courthouse: Judicial Chamber. National Institute of Building Sciences. Available at https://www.wbdg.org/spacetypes/courthouse-judicial-chamber

Thacker, G. 2017. Federal Courthouse. Design Recommendations: Building Types. National Institute of Building Sciences. Available at: https://www.wbdg.org/building-types/federal-courthouse-1

\section{Supplementary Design Guides}

Griebel, M. and T.S. Phillips. 2001. Architectural Design for Security in Courthouse Facilities. The Annals of the American Academy of Political and Social Science 576(1):118-131.

GSA. 2012. Circulation: Defining and Planning. Washington, DC: US General Services Administration, Public Building Services.

Kimme \& Associates, Inc. 1998. Jail Design Guide, A Resource for Small and Medium-Sized Jails. US Department of Justice, National Institute of Corrections.

Green Courthouse Design Concepts. 1997. Washington, DC: Public Buildings Service, US General Services Administration. Available at: https://www.wbdg.org/FFC/GSA/green2.pdf

National Association for Court Management (NACM). Achieving and Sustaining the Green Court: 2009 Mini Guide.

State-specific Courthouse Design Guides

California Trial Court Facilities Standards 2011(draft). 2014. San Francisco, CA: Judicial Council of California, Administrative Office of the Courts. http://www.courts.ca.gov/documents/ctcfs2011.pdf

Guidelines for New York State Court Facilities. 2009. New York State Unified Court System. PART 34, Administrative Rules of the Unified Court System \& Uniform Rules of the Trial Courts. https://www.nycourts.gov/rules/chiefjudge/34.shtml

Hardenbergh, D. 2015. Virginia Courthouse Facility Guidelines. Richmond, VA: Office of the Executive Secretary, Supreme Court of Virginia.

Kentucky Court Facilities Criteria. 2007. Project Development Guide Section II, Kentucky Court of Justice: Court Facilities Criteria. Frankfort, KY: Kentucky Administrative Office of the Court. http://courts.ky.gov/courtprograms/judicialconstruction/Documents/ProjectDevelopmentGuideSectio nII.pdf

Kentucky Court Facilities Design Guide. 2007. Project Development Guide Section III, Kentucky Court Facilities: Design and Construction. Frankfort, KY: Kentucky Administrative Office of the Court. 
http://courts.ky.gov/courtprograms/judicialconstruction/Documents/ProjectDevelopmentGuideSectio nIII.pdf

Minimum Courtroom Standards in the State of Illinois. 2011. Supreme Court of Illinois. www.illinoiscourts.gov/SupremeCourt/Policies/Pdf/Courtroom_Standards.pdf

The Michigan Courthouse: A Planning and Design Guide for Trial Court Facilities. 2000. Lansing, MI: Michigan Court Facilities Standards Project Advisory Committee. http://courts.mi.gov/Administration/SCAO/Resources/Documents/standards/FacilityStandards.pdf

Nebraska Courts Facility Planning: Guidelines and Standards. 1999. Supreme Court of Nebraska. http://nlc1.nlc.state.ne.us/epubs/S3200/B002-1999.pdf

Utah Judicial Facility Design Standards. 2016. State of Utah Judicial Branch. https://www.utcourts.gov/admin/facilities/docs/Utah_Judicial_Facility_Design_Standards.pdf

Evolution of Courthouse Over the Years

American Bar Association (ABA). 1993. Twenty Years of Courthouse Design Revisited - Supplement to The American Courthouse. Chicago, IL: American Bar Association Judicial Administration Division, National Center for State Courts, State Justice Institute. https://ncsc.contentdm.oclc.org/digital/collection/facilities/id/67/rec/1

Dixon, H.B. (Hon.). 2011. The Evolution of a High-Technology Courtroom. Future Trends in State Courts 2011: 28-32. Williamsburg, VA: National Center for State Courts.

Hall, N. 2009. Green Courthouse Planning and Design. Future Trends in State Courts 2009: 2731. Williamsburg, VA: National Center for State Courts.

Hall, N. 2010. Implementing Collegial Chambers as a Means for Courtroom Sharing. Future Trends in State Courts 2010: 85-89. Williamsburg, VA: National Center for State Courts.

Hardenbergh, D. 2004. Trends in Courthouse Design. Future Trends in State Courts 2004: 119-122. Williamsburg, VA: National Center for State Courts.

Yeh, C.M., D. Hardenbergh, T. Phillips. 2010b.Thirty Years of Courthouse Design, The Retrospectives: 1980-2010. National Center for State Courts. Presented at the 7th International Conference on Justice Design, Boston, MA, November 2010.

$\underline{\text { Courthouse Operation }}$

American Bar Association (ABA). 2017. How Courts Work. https://www.americanbar.org/groups/public_education/resources/law_related_education_network/ho w_courts_work.html

Offices of the United States Attorneys. 2017. Introduction to the Federal Court System. Washington, D.C.: US Department of Justice. https://www.justice.gov/usao/justice-101/federal-courts

Administrative Office of the US Courts. 2016. The Federal Court System in the United States: An Introduction for Judges and Judicial Administrators in Other Countries. Washington, D.C.: United States Courts. http://www.uscourts.gov/sites/default/files/federalcourtssystemintheus.pdf

US Courts. 2017. About Federal Courts: Court Role and Structure. Washington, D.C.: United States Courts. http://www.uscourts.gov/about-federal-courts/court-role-and-structure 
Courts Statistics Project. 2013. State Court Structure Charts. Williamsburg, VA: National Center for State Courts. http://www.courtstatistics.org/Other-Pages/State_Court_Structure_Charts.aspx

\section{$\underline{\text { Database }}$}

Schauffler, R., R. LaFountain, S. Strickland, K. Holt, and K. Genthon, eds. 2017. Court Statistics Project DataViewer. Williamsburg, VA: National Center for State Courts. http://www.courtstatistics.org/.

Strickland, S., R. Schauffler, R. LaFountain \& K. Holt, eds. 2017. Interactive State Court Organization App. Williamsburg, VA: National Center for State Courts. http://www.ncsc.org/sco.

EIA. 2015. 2012 CBECS Public Use Microdata File. US Energy Information Administration https://www.eia.gov/consumption/commercial/data/2012/index.php?view=microdata

EIA. 2008. 2003 CBECS Public Use Microdata File. US Energy Information Administration https://www.eia.gov/consumption/commercial/data/2003/index.php?view=microdata

EIA. 1996. 1992 CBECS Public Use Microdata File. US Energy Information Administration https://www.eia.gov/consumption/commercial/data/1992/index.php?view=microdata

GSA. 2017b. The Portfolio Data on Courthouses. US General Services Administration.

\section{$\underline{\text { Documented Courthouse Projects }}$}

Hardenbergh, D. (ed.). 1992. Retrospective of Courthouse Design 1980-1991.Williamsburg, VA: National Center for State Courts.

Hardenbergh, D., and T. S. Phillips (eds.). 2001. Retrospective of Courthouse Design, 19912001. Williamsburg, VA: National Center for State Courts.

Yeh, C.M., D. Hardenbergh, T. Phillips (eds.). 2010a. Retrospective of Courthouse Design 2001-2010. Williamsburg, VA: National Center for State Courts.

AIA. 2017. Justice Facilities Review (JFR) 1997-2016 Archive. The American Institute of Architects. https://network.aia.org/academyofarchitectureforjustice/viewdocument/justice-facilities-r 
APPENDIX A. 2012 CBECS DATA

\section{NUMBER OF BUILDINGS AND FLOOR SPACE BY BUILDING ACTIVITY SUBCATEGORIES}

\begin{tabular}{|c|c|c|c|c|}
\hline & $\begin{array}{c}\text { Number of } \\
\text { buildings } \\
\text { (thousand) }\end{array}$ & $\begin{array}{c}\text { Total floor space } \\
\text { (million square } \\
\text { feet) }\end{array}$ & \begin{tabular}{|c|} 
Number of \\
buildings (\% of \\
all buildings) \\
\end{tabular} & $\begin{array}{c}\text { Total floor space } \\
\text { (\% of all } \\
\text { buildings) }\end{array}$ \\
\hline All buildings & 5,557 & 87,093 & & \\
\hline \multicolumn{5}{|l|}{ Principal building activity (expanded) } \\
\hline Education & 389 & 12,239 & $7.0 \%$ & $14.1 \%$ \\
\hline College or university & 27 & 1,883 & $0.5 \%$ & $2.2 \%$ \\
\hline $\mathrm{K}-12$ & 232 & 9,175 & $4.2 \%$ & $10.5 \%$ \\
\hline Elementary or middle school & 189 & 6,118 & $3.4 \%$ & $7.0 \%$ \\
\hline High school & 43 & 3,056 & $0.8 \%$ & $3.5 \%$ \\
\hline Preschool or daycare & 68 & 431 & $1.2 \%$ & $0.5 \%$ \\
\hline Other classroom education & 62 & 750 & $1.1 \%$ & $0.9 \%$ \\
\hline Food sales & 177 & 1,252 & $3.2 \%$ & $1.4 \%$ \\
\hline Convenience store $^{2}$ & 131 & 470 & $2.4 \%$ & $0.5 \%$ \\
\hline Grocery store or food market & 45 & 763 & $0.8 \%$ & $0.9 \%$ \\
\hline Other food sales & $\mathrm{Q}$ & $\mathrm{Q}$ & - & - \\
\hline Food service & 380 & 1,819 & $6.8 \%$ & $2.1 \%$ \\
\hline Fast food & 92 & 302 & $1.7 \%$ & $0.3 \%$ \\
\hline Restaurant or cafeteria & 179 & 1,039 & $3.2 \%$ & $1.2 \%$ \\
\hline Bar, pub, or lounge & 71 & 350 & $1.3 \%$ & $0.4 \%$ \\
\hline Other food service & 37 & 128 & $0.7 \%$ & $0.1 \%$ \\
\hline Health care & 157 & 4,155 & $2.8 \%$ & $4.77 \%$ \\
\hline Inpatient & 10 & 2,374 & $0.2 \%$ & $2.73 \%$ \\
\hline Outpatient & 147 & 1,781 & $2.6 \%$ & $2.04 \%$ \\
\hline Office (diagnostic) & 60 & 510 & $1.1 \%$ & $0.6 \%$ \\
\hline Clinic or other outpatient & 87 & 1,271 & $1.6 \%$ & $1.5 \%$ \\
\hline Lodging & 158 & 5,826 & $2.8 \%$ & $6.7 \%$ \\
\hline Hotel & 30 & 2,717 & $0.5 \%$ & $3.1 \%$ \\
\hline Motel or inn & 61 & 602 & $1.1 \%$ & $0.7 \%$ \\
\hline Dormitory, fraternity, or sorority & 25 & 805 & $0.4 \%$ & $0.9 \%$ \\
\hline Nursing home or assisted living & 30 & 1,275 & $0.5 \%$ & $1.5 \%$ \\
\hline Other lodging & 13 & 426 & $0.2 \%$ & $0.5 \%$ \\
\hline Mercantile & 602 & 11,330 & $10.8 \%$ & $13.0 \%$ \\
\hline Retail (other than mall) & 438 & 5,439 & $7.9 \%$ & $6.2 \%$ \\
\hline Retail store & 336 & 4,504 & $6.0 \%$ & $5.2 \%$ \\
\hline Vehicle dealership & 43 & 559 & $0.8 \%$ & $0.6 \%$ \\
\hline Other retail & 59 & 376 & $1.1 \%$ & $0.4 \%$ \\
\hline Enclosed and strip malls & 164 & 5,890 & $3.0 \%$ & $6.8 \%$ \\
\hline Strip shopping center & 163 & 5,087 & $2.9 \%$ & $5.8 \%$ \\
\hline Enclosed mall & 1 & 803 & $0.0 \%$ & $0.9 \%$ \\
\hline Office & 1,012 & 15,952 & $18.2 \%$ & $18.3 \%$ \\
\hline Administrative or professional & 558 & 8,937 & $10.0 \%$ & $10.3 \%$ \\
\hline Bank or other financial & 91 & 920 & $1.6 \%$ & $1.1 \%$ \\
\hline Government & 113 & 2,655 & $2.0 \%$ & $3.0 \%$ \\
\hline Medical (non-diagnostic) & 50 & 302 & $0.9 \%$ & $0.3 \%$ \\
\hline Mixed-use & 125 & 2,656 & $2.2 \%$ & $3.0 \%$ \\
\hline Other office & 74 & 482 & $1.3 \%$ & $0.6 \%$ \\
\hline Public assembly & 352 & 5,559 & $6.3 \%$ & $6.4 \%$ \\
\hline Library & 24 & 761 & $0.4 \%$ & $0.9 \%$ \\
\hline
\end{tabular}




\begin{tabular}{|l|c|c|c|c|}
\hline & $\begin{array}{c}\text { Number of } \\
\text { buildings } \\
\text { (thousand) }\end{array}$ & $\begin{array}{c}\text { Total floor space } \\
\text { (million square } \\
\text { feet) }\end{array}$ & $\begin{array}{c}\text { Number of } \\
\text { buildings (\% of } \\
\text { all buildings) }\end{array}$ & $\begin{array}{c}\text { Total floor space } \\
\text { (\% of all } \\
\text { buildings) }\end{array}$ \\
\hline Entertainment or culture & 51 & 1,266 & $0.9 \%$ & $1.5 \%$ \\
Recreation & 100 & 1,898 & $1.8 \%$ & $2.2 \%$ \\
Social or meeting & 135 & 948 & $2.4 \%$ & $1.1 \%$ \\
Other assembly & 41 & 685 & $0.7 \%$ & $0.8 \%$ \\
Public order and safety & 84 & 1,440 & $1.5 \%$ & $1.7 \%$ \\
Fire or police station & 69 & 572 & $1.2 \%$ & $0.7 \%$ \\
Courthouse or probation office & $\mathbf{6}$ & $\mathbf{4 3 6}$ & $\mathbf{0 . 1 \%}$ & $\mathbf{0 . 5 \%}$ \\
Other public order & 9 & 432 & $0.2 \%$ & $0.5 \%$ \\
Religious worship & 412 & 4,557 & $7.4 \%$ & $5.2 \%$ \\
Service & 619 & 4,630 & $11.1 \%$ & $5.3 \%$ \\
Post office or postal center & 30 & 446 & $0.5 \%$ & $0.5 \%$ \\
Repair shop & 84 & 535 & $1.5 \%$ & $0.6 \%$ \\
Vehicle service or repair & 214 & 1,653 & $3.9 \%$ & $1.9 \%$ \\
Vehicle storage or maintenance & 176 & 1,311 & $3.2 \%$ & $1.5 \%$ \\
Other service & 114 & 685 & $2.1 \%$ & $0.8 \%$ \\
Warehouse and storage & 796 & 13,077 & $14.3 \%$ & $15.0 \%$ \\
Nonrefrigerated & 787 & 12,635 & $14.2 \%$ & $14.5 \%$ \\
Warehouse & 427 & 5,377 & $7.7 \%$ & $6.2 \%$ \\
Distribution or shipping center & 151 & 5,688 & $2.7 \%$ & $6.5 \%$ \\
Self storage units & 209 & 1,571 & $3.8 \%$ & $1.8 \%$ \\
Refrigerated & 8 & 443 & $0.1 \%$ & $0.5 \%$ \\
Other & 125 & 2,002 & $2.2 \%$ & $2.3 \%$ \\
Laboratory & 16 & 467 & $0.3 \%$ & $0.5 \%$ \\
Other & 109 & 1,535 & $2.0 \%$ & $1.8 \%$ \\
Vacant & 296 & 3,256 & $5.3 \%$ & $3.7 \%$ \\
\hline
\end{tabular}




\section{MAJOR FUEL CONSUMPTION AND GROSS ENERGY INTENSITIES BY BUILDING ACTIVITY SUBCATEGORIES}

\begin{tabular}{|c|c|c|c|c|}
\hline & \multicolumn{3}{|c|}{ Sum of major fuel consumption } & \multirow{2}{*}{$\begin{array}{c}\text { Total fuel } \\
\text { consumption ( } \% \\
\text { of all buildings) }\end{array}$} \\
\hline & $\begin{array}{c}\text { Total } \\
\text { (trillion Btu) }\end{array}$ & $\begin{array}{l}\text { Per building } \\
\text { (million Btu) }\end{array}$ & $\begin{array}{l}\text { Per square foot } \\
\text { (thousand Btu) }\end{array}$ & \\
\hline All buildings & 6,963 & 1,253 & 80.0 & \\
\hline \multicolumn{5}{|l|}{ Principal building activity (expanded) } \\
\hline Education & 842 & 2,166 & 68.8 & $12.1 \%$ \\
\hline College or university & 231 & 8,506 & 122.9 & $3.3 \%$ \\
\hline $\mathrm{K}-12$ & 536 & 2,311 & 58.4 & $7.7 \%$ \\
\hline Elementary or middle school & 336 & 1,778 & 54.9 & $4.8 \%$ \\
\hline High school & 200 & 4,675 & 65.3 & $2.9 \%$ \\
\hline Preschool or daycare & 29 & 423 & 66.4 & $0.4 \%$ \\
\hline Other classroom education & 46 & 744 & 61.4 & $0.7 \%$ \\
\hline Food sales & 262 & 1,483 & 209.5 & $3.8 \%$ \\
\hline Convenience store ${ }^{2}$ & 102 & 778 & 216.3 & $1.5 \%$ \\
\hline Grocery store or food market & 157 & 3,504 & 205.5 & $2.3 \%$ \\
\hline Other food sales & Q & Q & $\mathrm{Q}$ & - \\
\hline Food service & 514 & 1,355 & 282.7 & $7.4 \%$ \\
\hline Fast food & 122 & 1,318 & 402.9 & $1.8 \%$ \\
\hline Restaurant or cafeteria & 318 & 1,783 & 306.3 & $4.6 \%$ \\
\hline Bar, pub, or lounge & 54 & 761 & 155.2 & $0.8 \%$ \\
\hline Other food service & 20 & 534 & 156.4 & $0.3 \%$ \\
\hline Health care & 718 & 4,578 & 172.7 & $10.3 \%$ \\
\hline Inpatient & 549 & 57,281 & 231.1 & $7.9 \%$ \\
\hline Outpatient & 169 & 1,147 & 94.8 & $2.4 \%$ \\
\hline Office (diagnostic) & 35 & 580 & 68.6 & $0.5 \%$ \\
\hline Clinic or other outpatient & 134 & 1,541 & 105.3 & $1.9 \%$ \\
\hline Lodging & 564 & 3,574 & 96.9 & $8.1 \%$ \\
\hline Hotel & 273 & 9,095 & 100.4 & $3.9 \%$ \\
\hline Motel or inn & 43 & 710 & 71.8 & $0.6 \%$ \\
\hline Dormitory, fraternity, or sorority & 63 & 2,562 & 78.4 & $0.9 \%$ \\
\hline Nursing home or assisted living & 154 & 5,219 & 120.9 & $2.2 \%$ \\
\hline Other lodging & 31 & 2,431 & 73.3 & $0.4 \%$ \\
\hline Mercantile & 1,008 & 1,673 & 88.9 & $14.5 \%$ \\
\hline Retail (other than mall) & 364 & 830 & 66.9 & $5.2 \%$ \\
\hline Retail store & 299 & 888 & 66.3 & $4.3 \%$ \\
\hline Vehicle dealership & 40 & 916 & 70.7 & $0.6 \%$ \\
\hline Other retail & 26 & 434 & 67.9 & $0.4 \%$ \\
\hline Enclosed and strip malls & 644 & 3,924 & 109.3 & $9.2 \%$ \\
\hline Strip shopping center & 590 & 3,624 & 115.9 & $8.5 \%$ \\
\hline Enclosed mall & 54 & 39,337 & 67.5 & $0.8 \%$ \\
\hline Office & 1,241 & 1,226 & 77.8 & $17.8 \%$ \\
\hline Administrative or professional & 755 & 1,352 & 84.4 & $10.8 \%$ \\
\hline Bank or other financial & 79 & 865 & 85.7 & $1.1 \%$ \\
\hline Government & 194 & 1,715 & 73.2 & $2.8 \%$ \\
\hline Medical (non-diagnostic) & 18 & 347 & 57.9 & $0.3 \%$ \\
\hline Mixed-use & 165 & 1,315 & 61.9 & $2.4 \%$ \\
\hline Other office & 31 & 419 & 64.8 & $0.4 \%$ \\
\hline Public assembly & 480 & 1,363 & 86.3 & $6.9 \%$ \\
\hline Library & 76 & 3,184 & 99.5 & $1.1 \%$ \\
\hline Entertainment or culture & 115 & 2,243 & 90.7 & $1.7 \%$ \\
\hline Recreation & 147 & 1,468 & 77.6 & $2.1 \%$ \\
\hline Social or meeting & 58 & 428 & 61.1 & $0.8 \%$ \\
\hline
\end{tabular}




\begin{tabular}{|c|c|c|c|c|}
\hline & Sum & major fuel con & mption & Total fuel \\
\hline & $\begin{array}{c}\text { Total } \\
\text { (trillion Btu) }\end{array}$ & $\begin{array}{l}\text { Per building } \\
\text { (million Btu) }\end{array}$ & $\begin{array}{l}\text { Per square foot } \\
\text { (thousand Btu) }\end{array}$ & $\begin{array}{c}\text { consumption ( } \% \\
\text { of all buildings) }\end{array}$ \\
\hline Other assembly & 84 & 2,042 & 123.0 & $1.2 \%$ \\
\hline Public order and safety & 133 & 1,583 & 92.2 & $1.9 \%$ \\
\hline Fire or police station & 41 & 601 & 72.4 & $0.6 \%$ \\
\hline Courthouse or probation office & 41 & 6,574 & 94.7 & $0.6 \%$ \\
\hline Other public order & 50 & 5,783 & 115.9 & $0.7 \%$ \\
\hline Religious worship & 173 & 421 & 38.0 & $2.5 \%$ \\
\hline Service & 272 & 440 & 58.7 & $3.9 \%$ \\
\hline Post office or postal center & 22 & 716 & 48.7 & $0.3 \%$ \\
\hline Repair shop & 23 & 275 & 43.4 & $0.3 \%$ \\
\hline Vehicle service or repair & 104 & 486 & 62.9 & $1.5 \%$ \\
\hline Vehicle storage or maintenance & 64 & 363 & 48.8 & $0.9 \%$ \\
\hline Other service & 59 & 519 & 86.0 & $0.8 \%$ \\
\hline Warehouse and storage & 429 & 539 & 32.8 & $6.2 \%$ \\
\hline Nonrefrigerated & 370 & 470 & 29.3 & $5.3 \%$ \\
\hline Warehouse & 176 & 412 & 32.7 & $2.5 \%$ \\
\hline Distribution or shipping center & 171 & 1,130 & 30.1 & $2.5 \%$ \\
\hline Self storage units & 23 & 112 & 14.9 & $0.3 \%$ \\
\hline Refrigerated & 59 & 6,898 & 132.5 & $0.8 \%$ \\
\hline Other & 286 & 2,293 & 142.9 & $4.1 \%$ \\
\hline Laboratory & 118 & 7,591 & 252.0 & $1.7 \%$ \\
\hline Other & 168 & 1,541 & 109.7 & $2.4 \%$ \\
\hline Vacant & 41 & 140 & 12.7 & $0.6 \%$ \\
\hline
\end{tabular}




\section{APPENDIX B. GSA US COURTHOUSE PORTFOLIO DATA}

Nomenclature (Source: GSA 2012):

Net Area (NSF): Includes workspaces (office and workstations), dedicated support (conference rooms, supply rooms, etc.), shared support (e.g. shared copier rooms, break rooms), and special mission-critical support spaces (e.g. evidence rooms, laboratories, courtrooms)

Circulation Area: Circulation Area can be broken into two types: primary and secondary. Primary circulation is the main route connecting the building core and common spaces, such as elevator lobbies, exit stairs, and core toilets. Secondary circulation is the aisles between individual and support spaces

Usable Area (USF): Includes Net Area and Circulation Area but excludes building core and common spaces such as elevators, exit stairs, mechanical rooms, and core toilets. For multi-tenant floors, common building corridors are excluded from Usable Area and instead, are included in the Rental Area.

Rentable Area (RSF): Usable Area and building common spaces, such as the building lobbies, egress corridors, service spaces (e.g. mechanical/electrical, toilet, janitorial), and loading docks. Excludes major vertical penetrations, such as stairwells, elevators, and major shaft spaces.

Gross Area (GSF): Includes exterior wall thickness, and all vertical penetrations (e.g. mechanical/electrical, plumbing, elevator shafts, stairwells), as well as basements, garages, and penthouses. Excludes parking lots and loading docks outside the building line. 
GSA Courthouse Portfolio Data ${ }^{14}$ :

(Source: GSA 2017b)

\begin{tabular}{|c|c|c|c|c|c|c|c|c|c|}
\hline Region & Building Name & City & $\begin{array}{l}\text { State } \\
\text { Code }\end{array}$ & $\begin{array}{c}\text { Date } \\
\text { Construction } \\
\text { Completed } \\
\end{array}$ & $\begin{array}{c}\text { Building } \\
\text { GSF }\end{array}$ & $\begin{array}{c}\text { Building } \\
\text { RSF }\end{array}$ & $\begin{array}{c}\text { Building } \\
\text { USF }\end{array}$ & $\begin{array}{l}\text { Parking } \\
\text { Space }\end{array}$ & $\begin{array}{l}\text { Courts } \\
\text { USF }\end{array}$ \\
\hline 4 & FRANK JOHNSON ANNEX & Montgomery & $\mathrm{AL}$ & 2001 & 325,866 & 261,371 & 205,510 & 35,282 & 183,330 \\
\hline 4 & FB-CT & Anniston & $\mathrm{AL}$ & 1906 & 34,342 & 28,791 & 14,870 & & 9,349 \\
\hline 4 & FB-CT & Dothan & $\mathrm{AL}$ & 1911 & 21,223 & 17,873 & 10,917 & & 7,914 \\
\hline 4 & $\mathrm{PO}-\mathrm{CT}$ & Huntsville & $\mathrm{AL}$ & 1936 & 40,929 & 37,248 & 23,946 & & 23,312 \\
\hline 4 & JOHN A CAMPBELL USCT & Mobile & $\mathrm{AL}$ & 1932 & 115,014 & 103,521 & 73,034 & & 71,820 \\
\hline 4 & G. W. ANDREWS FB-CT & Opelika & $\mathrm{AL}$ & 1918 & 22,796 & 19,283 & 9,320 & & 7,257 \\
\hline 4 & HUGO L BLACK USCT & Birmingham & $\mathrm{AL}$ & 1987 & 194,519 & 160,102 & 124,181 & 17,964 & 123,188 \\
\hline 7 & LITTLE ROCK OLD USPO/CTHS & Little Rock & AR & 1881 & 92,415 & 73,162 & 46,949 & 4,394 & 40,219 \\
\hline 7 & TEXARKANA USPO/COURTHOUSE & Texarkana & AR & 1933 & 100,212 & 86,190 & 60,254 & & 30,623 \\
\hline 7 & JP HAMMERSCHMIDT FED BLDG/CTHS & Fayetteville & AR & 1974 & 64,186 & 57,353 & 38,609 & & 37,616 \\
\hline 7 & $\begin{array}{l}\text { RICHARD SHEPPARD ARNOLD US } \\
\text { COURTHOUSE ANNEX }\end{array}$ & Little Rock & AR & 2007 & 254,911 & 153,323 & 101,968 & 22,371 & 101,712 \\
\hline 9 & JAMES A. WALSH COURTHOUSE & Tucson & $\mathrm{AZ}$ & 1930 & 77,067 & 68,468 & 42,734 & & 40,382 \\
\hline 9 & SANDRA D. O'CONNOR COURTHOUSE & Phoenix & $\mathrm{AZ}$ & 2000 & 579,922 & 480,824 & 332,653 & 71,415 & 302,901 \\
\hline 9 & EVO A. DECONCINI COURTHOUSE & Tucson & AZ & 2000 & 432,591 & 348,668 & 261,067 & 38,427 & 261,067 \\
\hline 9 & US COURT HOUSE & Los Angeles & $\mathrm{CA}$ & 1940 & 885,285 & 757,792 & 538,818 & 12,966 & 330,102 \\
\hline 9 & J. WEINBERGER COURTHOUSE & San Diego & $\mathrm{CA}$ & 1913 & 73,180 & 63,757 & 42,825 & & 42,825 \\
\hline 9 & EDWARD R ROYBAL FB \& CH & Los Angeles & $\mathrm{CA}$ & 1993 & $1,307,777$ & 768,850 & 538,243 & 415,206 & 366,337 \\
\hline 9 & ROBERT E. COYLE FEDERAL COURT & Fresno & $\mathrm{CA}$ & 2005 & 481,785 & 392,763 & 271,923 & 44,124 & 250,463 \\
\hline 9 & LOS ANGELES FEDERAL COURTHOUSE & Los Angeles & $\mathrm{CA}$ & 2016 & 630,099 & 529,359 & 384,075 & 43,609 & 366,169 \\
\hline 8 & BYRON WHITE US CRTHS & Denver & $\mathrm{CO}$ & 1916 & 269,311 & 234,414 & 144,627 & 5,196 & 140,513 \\
\hline 8 & ALFRED A. ARRAJ & Denver & $\mathrm{CO}$ & 2002 & 327,618 & 251,425 & 187,023 & 31,335 & 186,530 \\
\hline 1 & BRIEN MCMAHON USCH\&FB & Bridgeport & CT & 1967 & 166,024 & 119,684 & 86,475 & 14,709 & 58,350 \\
\hline 11 & ELIJAH BARRETT PRETTYMAN BLDG & Washington & DC & 1952 & 627,737 & 530,519 & 409,701 & 22,452 & 368,651 \\
\hline 11 & HOWARD T. MARKEY NATIONAL CRTS & Washington & DC & 1965 & 261,434 & 198,218 & 150,210 & 32,744 & 137,475 \\
\hline 11 & WILLIAM B. BRYANT ANNEX & Washington & DC & 2005 & 404,425 & 262,413 & 182,840 & 70,103 & 170,879 \\
\hline 3 & J. CALEB BOGGS CH FB & Wilmington & $\mathrm{DE}$ & 1973 & 202,722 & 182,580 & 130,166 & 4,224 & 110,225 \\
\hline 4 & BRYAN SIMPSON UNITES STATES & Jacksonville & FL & 2002 & 464,168 & 390,368 & 309,609 & 35,996 & 285,647 \\
\hline 4 & US COURTHOUSE ANNEX & Orlando & FL & 2007 & 468,051 & 321,037 & 235,029 & 79,491 & 230,576 \\
\hline 4 & US COURTHOUSE & Tallahassee & FL & 1937 & 46,518 & 40,294 & 29,590 & & 20,484 \\
\hline 4 & GOLDEN-COLLUM FB-CT & Ocala & FL & 1961 & 68,944 & 57,285 & 37,080 & & 34,670 \\
\hline
\end{tabular}

${ }^{14}$ Obtained from GSA with permission from the Federal Judiciary of the United States through a special request. 


\begin{tabular}{|c|c|c|c|c|c|c|c|c|c|}
\hline Region & Building Name & City & $\begin{array}{l}\text { State } \\
\text { Code }\end{array}$ & $\begin{array}{c}\text { Date } \\
\text { Construction } \\
\text { Completed }\end{array}$ & $\begin{array}{c}\text { Building } \\
\text { GSF }\end{array}$ & $\begin{array}{l}\text { Building } \\
\text { RSF }\end{array}$ & $\begin{array}{c}\text { Building } \\
\text { USF }\end{array}$ & $\begin{array}{l}\text { Parking } \\
\text { Space }\end{array}$ & $\begin{array}{l}\text { Courts } \\
\text { USF }\end{array}$ \\
\hline 4 & PAUL G ROGERS FB-CT & West Palm Beach & FL & 1972 & 92,186 & 73,245 & 53,930 & 11,976 & 53,930 \\
\hline 4 & C. CLYDE ATKINS US COURTHOUS & Miami & FL & 1982 & 201,017 & 146,677 & 109,525 & 31,052 & 102,828 \\
\hline 4 & FB-CT & Fort Lauderdale & FL & 1978 & 262,515 & 169,093 & 141,809 & 79,791 & 112,840 \\
\hline 4 & ELBERT P. TUTTLE US CRT OF APP & Atlanta & GA & 1910 & 201,296 & 172,347 & 117,701 & 1,399 & 117,340 \\
\hline 4 & US COURTHOUSE & Augusta & GA & 1916 & 57,485 & 51,121 & 27,907 & & 26,495 \\
\hline 4 & C.B. KING USCT & Albany & GA & 2001 & 82,448 & 60,981 & 42,749 & 14,551 & 42,465 \\
\hline 4 & $\mathrm{PO}-\mathrm{CT}$ & Columbus & GA & 1934 & 62,426 & 55,490 & 35,502 & 643 & 21,344 \\
\hline 4 & FB-CT & Gainesville & GA & 1910 & 55,756 & 48,227 & 33,981 & & 31,810 \\
\hline 4 & WILLIAM AUGUSTUS BOOTLE FB CH & Macon & GA & 1908 & 90,402 & 77,411 & 53,273 & & 46,413 \\
\hline 4 & FRANK M SCARLETT FB & Brunswick & GA & 1959 & 64,527 & 57,061 & 45,280 & 470 & 26,958 \\
\hline 4 & PRINCE H PRESTON FB & Statesboro & GA & 1963 & 32,956 & 30,018 & 19,962 & 321 & 11,691 \\
\hline 6 & UNITED STATES COURTHOUSE & Davenport & IA & 1933 & 79,872 & 68,391 & 47,499 & 4,076 & 47,012 \\
\hline 6 & U S COURTHOUSE & Des Moines & IA & 1929 & 97,470 & 73,482 & 54,589 & & 54,589 \\
\hline 5 & FED BLDG \& US CTHSE & Peoria & IL & 1938 & 116,877 & 105,659 & 67,931 & & 61,036 \\
\hline 5 & FED BLDG-PO-US CTHSE & Benton & IL & 1959 & 38,514 & 35,557 & 29,044 & & 28,831 \\
\hline 5 & EVERETT M. DIRKSEN & Chicago & $\mathrm{IL}$ & 1964 & $1,465,484$ & $1,213,656$ & 869,266 & 52,274 & 787,841 \\
\hline 5 & MELVIN PRICE FED. BL & East St Louis & IL & 1988 & 77,862 & 62,860 & 46,864 & 9,007 & 45,463 \\
\hline 5 & US COURTHOUSE & Urbana & IL & 1994 & 51,353 & 45,595 & 34,186 & 1,569 & 33,970 \\
\hline 5 & $\begin{array}{l}\text { E. ROSS ADAIR FEDERAL BLDG \& US } \\
\text { COURTHOUSE }\end{array}$ & Fort Wayne & IN & 1932 & 130,915 & 104,156 & 62,911 & & 50,156 \\
\hline 5 & BIRCH BAYH FED BLDG \& US CTHSE & Indianapolis & IN & 1905 & 527,335 & 362,830 & 215,929 & 13,679 & 155,915 \\
\hline 5 & CHARLES A HALLECK FEDERAL BLDG & Lafayette & IN & 1932 & 65,054 & 45,471 & 22,582 & & 12,500 \\
\hline 5 & LEE H HAMILTON F.B. \& US CTHSE & New Albany & IN & 1966 & 38,502 & 35,355 & 21,934 & & 18,466 \\
\hline 6 & U S COURT HOUSE & Wichita & KS & 1932 & 174,767 & 149,198 & 99,421 & 9,190 & 90,324 \\
\hline 4 & WILLIAM H. NATCHER FB-USCT & Bowling Green & KY & 1913 & 33,405 & 28,034 & 17,428 & & 15,477 \\
\hline 4 & PO-CT & Lexington & KY & 1934 & 108,772 & 91,540 & 64,384 & 2,215 & 63,131 \\
\hline 4 & FB-CT & London & KY & 1910 & 20,049 & 16,077 & 10,718 & & 4,236 \\
\hline 4 & FEDERAL BUILDING & Owensboro & KY & 1911 & 35,777 & 31,194 & 20,693 & & 17,426 \\
\hline 4 & FB-CT & Paducah & KY & 1938 & 57,220 & 48,028 & 30,389 & & 27,903 \\
\hline 7 & ALEXANDRIA USPO/COURTHOUSE & Alexandria & LA & 1933 & 48,409 & 41,751 & 25,984 & & 21,065 \\
\hline 7 & BATON ROUGE FED BLDG/COURTHOUS & Baton Rouge & LA & 1933 & 67,361 & 54,418 & 34,254 & & 24,006 \\
\hline 7 & MONROE FEDERAL BLDG/COURTHOUSE & Monroe & LA & 1934 & 49,059 & 40,939 & 25,481 & & 17,261 \\
\hline 7 & JM WISDOM COURTHOUSE & New Orleans & LA & 1915 & 249,478 & 181,106 & 110,181 & 35,342 & 109,974 \\
\hline 7 & H BOGGS FED BLDG/COURTHOUSE & New Orleans & LA & 1976 & 706,400 & 597,356 & 464,440 & 53,635 & 320,254 \\
\hline 7 & LONG FEDERAL BLDG & Baton Rouge & LA & 1994 & 186,809 & 149,638 & 111,417 & 10,233 & 105,134 \\
\hline 7 & JM SHAW COURTHOUSE & Lafayette & LA & 1999 & 215,152 & 178,528 & 132,301 & 17,243 & 124,012 \\
\hline
\end{tabular}




\begin{tabular}{|c|c|c|c|c|c|c|c|c|c|}
\hline Region & Building Name & City & $\begin{array}{l}\text { State } \\
\text { Code }\end{array}$ & $\begin{array}{c}\text { Date } \\
\text { Construction } \\
\text { Completed }\end{array}$ & $\begin{array}{l}\text { Building } \\
\text { GSF }\end{array}$ & $\begin{array}{l}\text { Building } \\
\text { RSF }\end{array}$ & $\begin{array}{l}\text { Building } \\
\text { USF }\end{array}$ & $\begin{array}{l}\text { Parking } \\
\text { Space }\end{array}$ & $\begin{array}{c}\text { Courts } \\
\text { USF }\end{array}$ \\
\hline 1 & JOHN J. MOAKLEY COURTHOUSE & Boston & MA & 1998 & 945,421 & 754,176 & 562,620 & 27,111 & 525,809 \\
\hline 1 & $\begin{array}{l}\text { HAROLD D. DONOHUE FEDERAL BUILDING \& } \\
\text { COURTHOUSE }\end{array}$ & Worcester & MA & 1932 & 108,676 & 94,694 & 62,795 & 989 & 56,244 \\
\hline 11 & SOUTHERN MD COURTHSE & Greenbelt & MD & 1994 & 280,450 & 224,728 & 156,025 & 23,547 & 148,970 \\
\hline 3 & EDWARD A GARMATZ US CH & Baltimore & MD & 1973 & 505,033 & 421,031 & 322,838 & 40,153 & 280,227 \\
\hline 1 & EDWARD T. GIGNOUX COURTHOUSE & Portland & ME & 1911 & 93,537 & 75,188 & 51,028 & & 49,332 \\
\hline 5 & THEODORE LEVIN US COURTHOUSE & Detroit & MI & 1934 & 765,824 & 631,871 & 395,848 & 8,356 & 360,168 \\
\hline 5 & FEDERAL BLDG & Ann Arbor & MI & 1977 & 108,546 & 71,365 & 51,144 & & 34,217 \\
\hline 5 & GERALD R. FORD BUILDING & Grand Rapids & MI & 1972 & 278,681 & 182,250 & 125,140 & 72,943 & 105,903 \\
\hline 5 & $\begin{array}{l}\text { EDWARD J. DEVITT US COURTHOUSE \& } \\
\text { FEDERAL BUILDING }\end{array}$ & Fergus Falls & $\mathrm{MN}$ & 1903 & 51,889 & 46,692 & 23,010 & & 15,160 \\
\hline 6 & CHARLES EVANS WHITTAKER CTHS & Kansas City & MO & 1998 & 674,508 & 535,579 & 363,734 & 30,952 & 338,849 \\
\hline 6 & THOMAS F. EAGLETON COURTHOUSE & Saint Louis & MO & 2000 & $1,239,728$ & 919,772 & 650,271 & 112,453 & 590,485 \\
\hline 4 & UNITED STATES COURTHOUSE & Natchez & MS & 1853 & 23,982 & 19,511 & 15,170 & & 15,170 \\
\hline 4 & T. G. ABERNETHY FB & Aberdeen & MS & 1973 & 56,270 & 52,733 & 37,725 & & 29,326 \\
\hline 4 & US POST OFFICE COURTHOUSE & New Bern & $\mathrm{NC}$ & 1935 & 47,932 & 43,084 & 28,022 & & 27,855 \\
\hline 4 & J HERBERT W SMALL FB \& US CTHS & Elizabeth City & $\mathrm{NC}$ & 1906 & 26,683 & 23,209 & 14,527 & & 11,505 \\
\hline 4 & L.R.PREYER FB-PO-CT & Greensboro & $\mathrm{NC}$ & 1933 & 128,653 & 116,126 & 78,000 & & 76,170 \\
\hline 4 & US COURTHOUSE & Greenville & $\mathrm{NC}$ & 1915 & 13,509 & 11,285 & 7,045 & & 6,894 \\
\hline 4 & UNITED STATES COURTHOUSE & Statesville & $\mathrm{NC}$ & 1939 & 38,636 & 33,940 & 24,680 & & 18,948 \\
\hline 4 & ALTON LENNON FB-CT & Wilmington & $\mathrm{NC}$ & 1919 & 64,914 & 53,423 & 35,646 & & 31,620 \\
\hline 8 & QUENTIN N. BURDICK CT ANNEX & Fargo & ND & 1998 & 122,926 & 95,274 & 65,609 & 14,325 & 65,609 \\
\hline 6 & HRUSKA US COURTHOUSE & Omaha & $\mathrm{NE}$ & 2000 & 364,173 & 286,570 & 202,204 & 25,734 & 189,313 \\
\hline 1 & WARREN B. RUDMAN US COURTHOUSE & Concord & NH & 1996 & 200,147 & 146,758 & 112,487 & 31,556 & 112,007 \\
\hline 3 & CLARKSON S FISHER FB-US CH & Trenton & $\mathrm{NJ}$ & 1932 & 178,057 & 162,620 & 112,631 & & 92,540 \\
\hline 2 & MLK, JR COURTHOUSE & Newark & $\mathrm{NJ}$ & 1992 & 368,879 & 308,416 & 200,834 & 25,019 & 198,106 \\
\hline 3 & CLARKSON S FISHER US CH ANNEX & Trenton & $\mathrm{NJ}$ & 1994 & 176,280 & 122,850 & 86,848 & 31,067 & 80,512 \\
\hline 3 & MITCHELL H COHEN US CH ANNEX & Camden & NJ & 1994 & 185,919 & 146,997 & 99,168 & 17,150 & 91,560 \\
\hline 7 & CAMPOS FEDERAL COURTHOUSE & Santa Fe & NM & 1899 & 49,141 & 41,900 & 30,265 & & 30,265 \\
\hline 7 & PETE DOMENICI COURTHOUSE & Albuquerque & NM & 1998 & 333,271 & 256,972 & 200,273 & 49,012 & 197,716 \\
\hline 7 & ALBUQUERQUE COURTHOUSE & Albuquerque & NM & 1931 & 75,847 & 62,621 & 38,779 & & 20,312 \\
\hline 9 & BRUCE R. THOMPSON COURTHOUSE & Reno & NV & 1995 & 206,884 & 171,310 & 130,729 & 14,304 & 112,988 \\
\hline 2 & EMANUEL CELLER US COURTHOUSE & Brooklyn & NY & 1963 & 290,883 & 264,935 & 199,508 & & 181,251 \\
\hline 2 & DANIEL P MOYNIHAN USCH & New York & NY & 1994 & 937,401 & 680,896 & 524,393 & 98,293 & 511,305 \\
\hline 2 & CHARLES L BRIEANT, JR USCTHS & White Plains & NY & 1995 & 149,472 & 126,137 & 103,632 & 7,935 & 102,927 \\
\hline 5 & POTTER STEWART US COURTHOUSE & Cincinnati & $\mathrm{OH}$ & 1938 & 528,522 & 438,503 & 279,101 & 945 & 232,821 \\
\hline
\end{tabular}




\begin{tabular}{|c|c|c|c|c|c|c|c|c|c|}
\hline Region & Building Name & City & $\begin{array}{l}\text { State } \\
\text { Code }\end{array}$ & $\begin{array}{c}\text { Date } \\
\text { Construction } \\
\text { Completed }\end{array}$ & $\begin{array}{l}\text { Building } \\
\text { GSF }\end{array}$ & $\begin{array}{l}\text { Building } \\
\text { RSF }\end{array}$ & $\begin{array}{l}\text { Building } \\
\text { USF }\end{array}$ & $\begin{array}{l}\text { Parking } \\
\text { Space }\end{array}$ & $\begin{array}{l}\text { Courts } \\
\text { USF }\end{array}$ \\
\hline 5 & METZENBAUM US COURTHOUSE & Cleveland & $\mathrm{OH}$ & 1910 & 227,221 & 183,175 & 100,537 & 6,302 & 58,741 \\
\hline 5 & KINNEARY US CTHSE & Columbus & $\mathrm{OH}$ & 1935 & 282,896 & 223,675 & 132,930 & 29,454 & 124,682 \\
\hline 5 & JAMES M. ASHLEY AND THOMAS W.L & Toledo & $\mathrm{OH}$ & 1932 & 91,767 & 81,507 & 52,355 & & 46,986 \\
\hline 5 & THOMAS D LAMBROS FOB & Youngstown & $\mathrm{OH}$ & 1995 & 44,608 & 33,331 & 24,964 & 7,792 & 24,725 \\
\hline 5 & CARL B STOKES US COURT HOUSE & Cleveland & $\mathrm{OH}$ & 2002 & 766,423 & 592,747 & 438,474 & 70,438 & 388,050 \\
\hline 7 & ED EDMONDSON US COURTHOUSE & Muskogee & $\mathrm{OK}$ & 1915 & 138,913 & 116,814 & 77,458 & 5,240 & 76,096 \\
\hline 7 & TULSA FEDERAL BLDG & Tulsa & $\mathrm{OK}$ & 1917 & 158,289 & 117,116 & 80,156 & 4,235 & 63,600 \\
\hline 7 & $\begin{array}{l}\text { WILLIAM J. HOLLOWAY, JR. UNITED STATES } \\
\text { COURTHOUSE }\end{array}$ & Oklahoma City & OK & 1960 & 308,691 & 271,321 & 211,374 & 17,140 & 182,110 \\
\hline 10 & J A REDDEN US CTHS & Medford & OR & 1916 & 33,804 & 29,834 & 20,510 & & 19,921 \\
\hline 10 & THE PIONEER CTHSE & Portland & OR & 1875 & 61,485 & 43,333 & 25,137 & 5,203 & 25,137 \\
\hline 10 & MARK O. HATFIELD US CRTHSE & Portland & OR & 1997 & 591,692 & 451,478 & 334,755 & 59,942 & 333,182 \\
\hline 10 & WAYNE L. MORSE US CTHSE & Eugene & OR & 2006 & 307,930 & 236,925 & 179,403 & 37,967 & 168,875 \\
\hline 3 & FB \& COURTHOUSE & Erie & PA & 1938 & 55,449 & 50,151 & 36,836 & & 35,935 \\
\hline 3 & $\begin{array}{l}\text { JOSEPH F, WEIS JR, UNITED STATES } \\
\text { COURTHOUSE }\end{array}$ & Pittsburgh & PA & 1934 & 824,782 & 627,551 & 430,979 & 100,439 & 342,927 \\
\hline 3 & HERMAN T. SCHNEEBELI FED BLDG & Williamsport & PA & 1976 & 81,305 & 74,701 & 59,064 & 861 & 38,972 \\
\hline 3 & JAMES A BYRNE US COURTHOUSE & Philadelphia & PA & 1974 & 864,618 & 735,594 & 536,214 & 60,621 & 521,868 \\
\hline 3 & EDWARD N CAHN FB-US CH & Allentown & $\mathrm{PA}$ & 1995 & 93,321 & 76,370 & 54,426 & 7,156 & 36,396 \\
\hline 3 & NEW CONSTRUCTION ANNEX & Erie & PA & 2004 & 64,499 & 53,021 & 29,874 & 5,616 & 28,516 \\
\hline 3 & ERIE LIBRARY & Erie & PA & 1898 & 34,207 & 28,690 & 18,867 & & 16,396 \\
\hline 2 & JOSE V. TOLEDO FB \& US CTHSE & San Juan & PR & 1914 & 128,715 & 102,962 & 57,706 & 3,940 & 54,966 \\
\hline 1 & FEDERAL BLDG USCT & Providence & RI & 1908 & 143,350 & 122,676 & 73,255 & & 61,610 \\
\hline 4 & CHARLES E. SIMON USCT & Aiken & $\mathrm{SC}$ & 1936 & 14,566 & 12,539 & 6,942 & & 6,304 \\
\hline 4 & G. ROSS ANDERSON JR. FB-CT & Anderson & $\mathrm{SC}$ & 1938 & 31,806 & 28,567 & 19,299 & & 17,756 \\
\hline 4 & MATTHEW PERRY USCT & Columbia & $\mathrm{SC}$ & 2003 & 213,305 & 182,059 & 140,753 & 11,895 & 140,608 \\
\hline 4 & $\mathrm{PO}-\mathrm{CT}$ & Charleston & $\mathrm{SC}$ & 1896 & 49,314 & 39,842 & 24,083 & & 19,545 \\
\hline 4 & C.F.HAYNSWORTH FBCT & Greenville & $\mathrm{SC}$ & 1937 & 86,013 & 74,413 & 46,693 & & 43,916 \\
\hline 4 & DONALD STUART RUSSELL FED CH & Spartanburg & $\mathrm{SC}$ & 1931 & 55,398 & 49,859 & 34,704 & 665 & 28,877 \\
\hline 4 & J.L. MCMILLAN FB-CT & Florence & $\mathrm{SC}$ & 1975 & 110,891 & 105,698 & 76,978 & & 60,114 \\
\hline 4 & HOLLINGS JUD CTR & Charleston & $\mathrm{SC}$ & 1988 & 41,180 & 25,466 & 18,118 & 7,160 & 17,899 \\
\hline 8 & US COURTHOUSE & Sioux Falls & SD & 1895 & 78,044 & 64,413 & 40,777 & & 37,670 \\
\hline 8 & FB-PO-CT & Pierre & SD & 1965 & 104,782 & 91,914 & 69,679 & & 44,097 \\
\hline 4 & L. CLURE MORTON US PO/CH & Cookeville & TN & 1916 & 24,874 & 22,392 & 13,662 & & 8,341 \\
\hline 4 & FB-PO-CT & Winchester & $\mathrm{TN}$ & 1966 & 39,684 & 37,059 & 26,401 & & 10,321 \\
\hline 7 & JM JONES FEDERAL BLDG & Amarillo & $\mathrm{TX}$ & 1939 & 68,448 & 62,747 & 41,849 & & 36,196 \\
\hline
\end{tabular}




\begin{tabular}{|c|c|c|c|c|c|c|c|c|c|}
\hline Region & Building Name & City & $\begin{array}{l}\text { State } \\
\text { Code }\end{array}$ & $\begin{array}{c}\text { Date } \\
\text { Construction } \\
\text { Completed } \\
\end{array}$ & $\begin{array}{l}\text { Building } \\
\text { GSF }\end{array}$ & $\begin{array}{c}\text { Building } \\
\text { RSF }\end{array}$ & $\begin{array}{c}\text { Building } \\
\text { USF }\end{array}$ & $\begin{array}{c}\text { Parking } \\
\text { Space }\end{array}$ & $\begin{array}{l}\text { Courts } \\
\text { USF }\end{array}$ \\
\hline 7 & J BROOKS FEDERAL BLDG & Beaumont & TX & 1934 & 158,999 & 131,915 & 88,158 & & 67,999 \\
\hline 7 & ELDON B. MAHON US COURTHOUSE & Fort Worth & $\mathrm{TX}$ & 1933 & 134,318 & 119,567 & 80,866 & & 77,805 \\
\hline 7 & WR BURKE COURTHOUSE & Lufkin & $\mathrm{TX}$ & 1935 & 24,432 & 16,613 & 10,658 & & 10,166 \\
\hline 7 & SB HALL JR FEDERAL BLDG & Marshall & TX & 1914 & 18,193 & 16,357 & 11,694 & & 11,694 \\
\hline 7 & $\begin{array}{l}\text { WILLIAM M. STEGER FEDERAL BLDG AND } \\
\text { UNITED STATES COURTHOUSE }\end{array}$ & Tyler & $\mathrm{TX}$ & 1934 & 63,197 & 49,756 & 31,057 & & 30,678 \\
\hline 7 & SHERMAN FEDERAL BLDG/COURTHOUS & Sherman & TX & 1907 & 34,820 & 25,919 & 16,682 & & 15,683 \\
\hline 7 & B CASEY COURTHOUSE & Houston & TX & 1962 & 536,944 & 495,484 & 375,083 & & 337,689 \\
\hline 7 & LAREDO FEDERAL BLDG/COURTHOUSE & Laredo & TX & 2004 & 152,681 & 125,480 & 95,098 & 13,940 & 95,098 \\
\hline 7 & ARMENADRIZ US COURTHOUSE & El Paso & TX & 2008 & 277,634 & 210,803 & 146,000 & 17,597 & 145,583 \\
\hline 7 & NEW AUSTIN COURTHOUSE & Austin & $\mathrm{TX}$ & 2012 & 250,995 & 186,676 & 135,489 & 23,362 & 134,630 \\
\hline 7 & J WOOD COURTHOUSE & San Antonio & $\mathrm{TX}$ & 1968 & 126,429 & 114,990 & 87,495 & & 86,609 \\
\hline 3 & FEDERAL BUILDING & Abingdon & VA & 1959 & 36,703 & 33,207 & 25,107 & & 24,245 \\
\hline 11 & MARTIN V.B. BOSTETTER CTHSE & Alexandria & VA & 1931 & 63,519 & 56,506 & 38,512 & & 34,750 \\
\hline 3 & BASCOM SLEMP FED BLDG & Big Stone Gap & VA & 1913 & 28,072 & 18,726 & 12,131 & & 7,312 \\
\hline 3 & WALTER E HOFFMAN US CH & Norfolk & VA & 1934 & 216,790 & 188,806 & 121,441 & & 116,481 \\
\hline 3 & LEWIS F POWELL JR US CH & Richmond & VA & 1858 & 207,794 & 161,568 & 97,724 & 7,051 & 80,479 \\
\hline 11 & AV BRYAN SR COURTHOUSE & Alexandria & VA & 1995 & 537,652 & 310,341 & 217,445 & 164,068 & 213,239 \\
\hline 10 & WILLIAM KENZO NAKAMURA CTHS & Seattle & WA & 1940 & 198,005 & 166,405 & 122,124 & 8,009 & 93,190 \\
\hline 10 & WM O DOUGLAS FBUSCT & Yakima & WA & 1912 & 58,282 & 52,987 & 35,562 & & 35,562 \\
\hline 5 & FED BLDG \& US CTHSE & Eau Claire & WI & 1909 & 37,964 & 27,482 & 16,620 & & 13,798 \\
\hline 5 & FED BLDG \& US CTHSE & Milwaukee & WI & 1899 & 491,835 & 429,037 & 261,155 & 9,345 & 219,966 \\
\hline 5 & R.W. KASTENMEIER US COURTHOUSE & Madison & WI & 1984 & 74,884 & 68,470 & 50,297 & 1,113 & 49,889 \\
\hline 3 & ELIZABETH KEE FEDERAL BUILDING & Bluefield & WV & 1911 & 42,945 & 37,730 & 24,811 & & 18,772 \\
\hline 3 & FB \& US COURTHOUSE & Wheeling & WV & 1914 & 79,296 & 64,823 & 41,694 & & 33,463 \\
\hline 3 & US COURTHOUSE & Martinsburg & WV & 1961 & 65,527 & 57,885 & 41,223 & 385 & 40,037 \\
\hline
\end{tabular}

